\title{
CARBON ISOTOPE STRATIGRAPHY AND GEOCHEMICAL STUDIES/INVESTIGATION FOR CHANGES ACROSS BENTONITES IN THE UPPER CRETACEOUS (CENOMANIAN-TURONIAN) SUCCESSIONS OF WCSB CANADA
}

\section{SULAIMAN OLAGOKE}

A thesis submitted to the Faculty of Graduate and Postdoctoral Affairs in partial fulfillment of the requirements for the degree of

Master of Science

in

Earth Sciences

Carleton University

Ottawa, Ontario 


\begin{abstract}
A high-resolution study of isotopic and stratigraphic trends that characterized the aftermath of volcanic events in Cenomanian-Turonian sections from the Western Canada Sedimentary Basin (WCSB) is presented. The research is based on $\delta^{18} \mathrm{O}, \delta^{13} \mathrm{C}, \delta^{13} \mathrm{C}_{\text {org }}$, TOC analyses of about 140 fossil (foraminifera, inoceramid) and whole rock samples combined with previously archived data.
\end{abstract}

Stable isotope $(\mathrm{O}, \mathrm{C})$ data were acquired from three sections in the WCSB; Vermilion River VR1 \& VR2 and the drill-core from well 6-34-30-8W4 (Youngstown), to (1) investigate the trends in the sedimentary sequences deposited in the aftermath of Cretaceous volcanic eruptions and (2) for chemostratigraphic correlation within the Western Interior Seaways (WIS) of North America.

Planktic foraminifera of the genera Heterohelix, and Hedbergella, and inoceramid shells used in the analysis were precipitated in isotopic equilibrium with sea water and show no significant diagenetic or vital effects; $\delta^{13} \mathrm{C}$ values range between $-8.86 \%$ and $3.72 \%$, $\delta^{18} \mathrm{O}$ value range from $-13.93 \%$ to $-3.77 \%$, and $\delta^{13} \mathrm{C}_{\mathrm{org}}$ value range between $-28.68 \%$ o to 23.94\%o. The $\delta^{13} \mathrm{C}$ values shift positively by about $\sim 5 \%$, the $\delta^{18} \mathrm{O}$ values shift negatively by about $\sim 5 \%$ and $\delta^{13} \mathrm{C}_{\mathrm{org}}$ values shift negatively by $\sim 1 \%$ all within the late Cenomanian. These shifts all coincided at the onset of the Ocean Anoxic Event 2 (OAE2), similar to other CTB sections within the WIS/WCSB and worldwide.

The results are similar to those obtained from other sections in the WIS/WCSB and generally reflect two major trends/events; the mid Cenomanian cool period and the warm late Cenomanian/early Turonian period, which incorporates the OAE2. 
The TOC as well as $\delta^{13} \mathrm{C}_{\text {org }}$ results indicate that the low organic content that characterized the mid Cenomanian Belle Fourche Formation, became relatively high by time of the deposition of the late Cenomanian Keld member/Second White Specks Formation, but again become low by the early Turonian. The $\mathrm{C} / \mathrm{N}$ ratio, $\delta^{13} \mathrm{C}_{\text {org }}$ and $\delta^{15} \mathrm{~N}$ results indicate that the main source of organic matter is from $\mathrm{C} 3$ plants of terrestrial origin.

Across the bentonites, $\delta^{18} \mathrm{O}, \delta^{13} \mathrm{C}_{\mathrm{org}}$ and TOC generally increases while $\delta^{13} \mathrm{C}$ decreases. The $\delta^{18} \mathrm{O}$ increases by $0.57-2.14 \%$ across the bentonites $\geq 5 \mathrm{~cm}$ thickness, indicating cooling of $\sim 2.28^{\circ} \mathrm{C}-8.56^{\circ} \mathrm{C}$. The environmental recovery time from the effects of volcanic events was found to be 8 to $18 \mathrm{kyr}$.

The observed $\delta^{13} \mathrm{C}$ and $\delta^{13} \mathrm{C}_{\text {org }}$ trends from the three sections from WCSB indicate that a correlation exists with the North American stratotype section of the CenomanianTuronian OAE2 boundary at Pueblo, Colorado. 


\section{ACKNOWLEDGMENTS}

I would like to express my sincere appreciations to my thesis advisors- Dr. Andreas Prokoph and Dr. R. Timothy Patterson for their support and guidance throughout the duration of this research. Their various contributions, invaluable expertise advice and constructive criticism during the laboratory work, data analysis and preparation of this dissertation are thankfully acknowledged. All the members of my examination committee are also thanked for finding time out their tight schedules to read through my dissertation.

The moral support and numerous forms of assistance received from the following family friends- Lameed Babalola, Khamis Salam-Alada, AbdulKareem Adinoyi, Mahammad Al-Delami, Akin Oshuntoye, Ruth Gbadeyan and Jeffrey Scott, throughout the period of my studentship and particularly at the time of preparing this thesis, are unquantifiable and are duly appreciated.

This research was funded through the NSERC research grant of Dr. Andreas Prokoph. The international student tuition waiver and Earth Sciences departmental scholarships have greatly helped me through this program. The bursary awards granted me by the Faculty of Graduate Studies and Research, are also kindly acknowledged.

The list of appreciations will not be complete without remembering my immediate and extended family members, especially my wife (Hassanah), our lovely children (Rahmatullah and Raheemah); my parents (Alhaj AbdulWahab Olagoke, Alhaja Fatimah Olagoke and Mrs Wasillah Olagoke); my brothers, sisters, uncles, aunts and in-laws, for their enduring moral support, prayers and patience throughout the duration of my studentship at Carleton University. 


\section{TABLE OF CONTENTS}

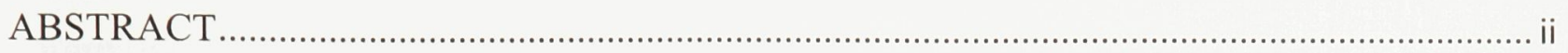

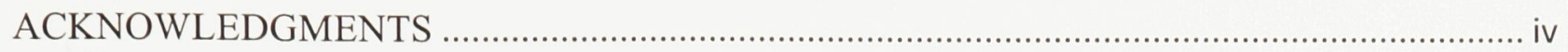

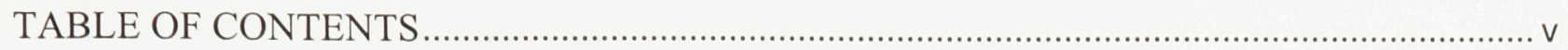

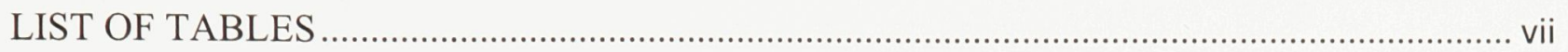

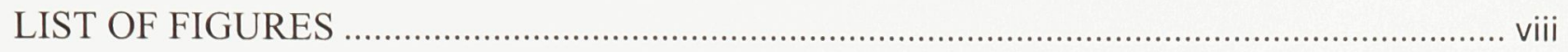

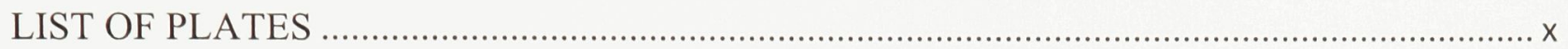

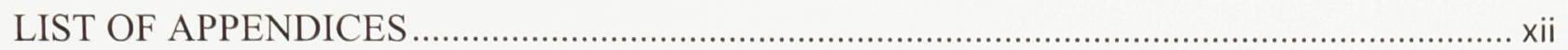

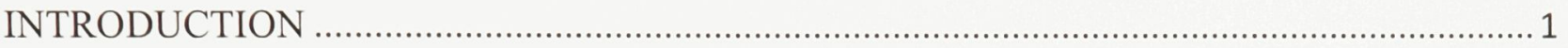

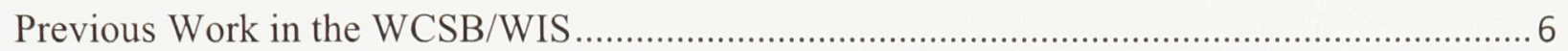

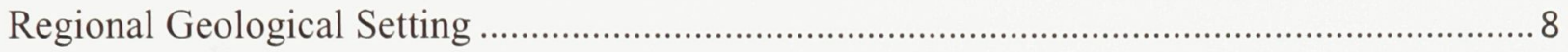

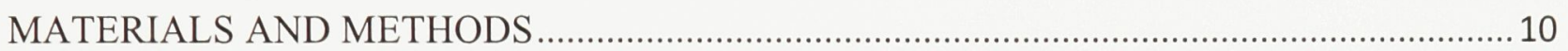

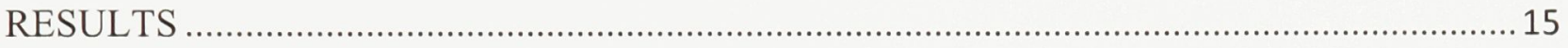

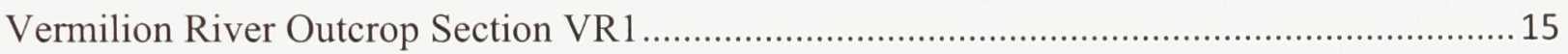

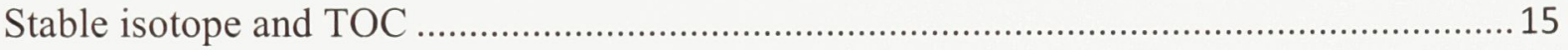

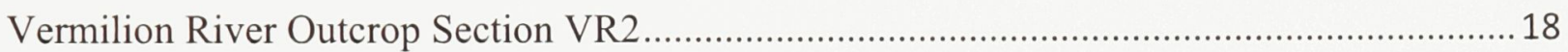

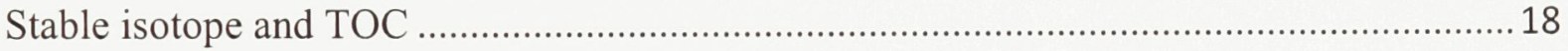

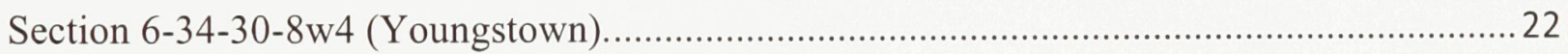

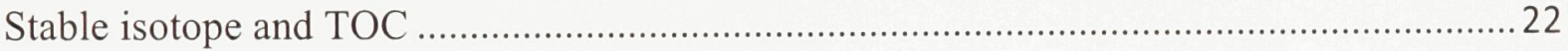

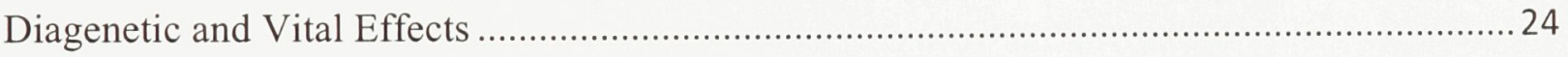

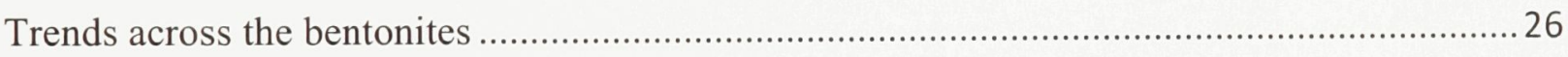

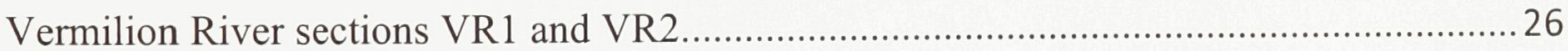

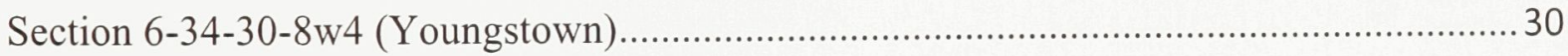

Magnitude of Events and Environmental Recovery ….................................................... 31

Synthesis/ Stratigraphic Correlation of Sections to Pueblo, USA …..................................... 31

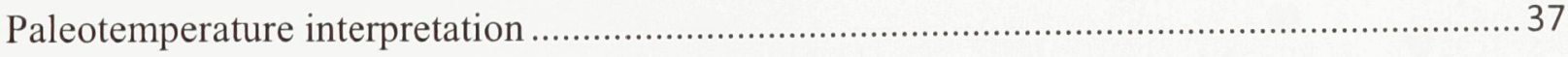

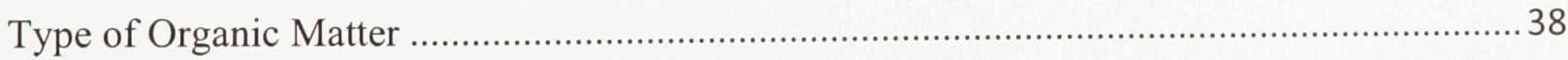

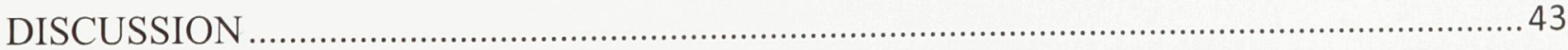

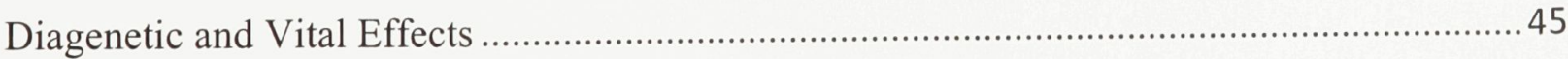

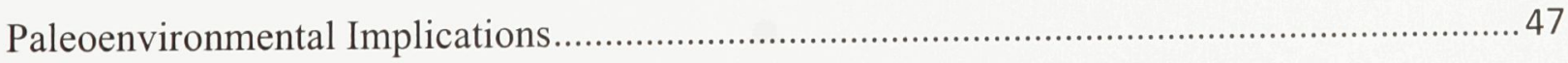

Magnitude of Events and Environmental Recovery ….................................................. 49 
REFERENCES .

APPENDICES

Appendix A: Geochemical Tables 60

Appendix B: Plates 


\section{LIST OF TABLES}

Table 1: Trends and bentonite thickness in the Vermilion River sections VR1 and VR2.27

Table 2: Trends and bentonite thickness in the Section 6-34-30-8w4 (Youngstown)...... 31

Table 3: Paleotemperature calculations using different scenarios based on various possible dilution factors (Fisher and Arthur, 2002)………………...................... 39

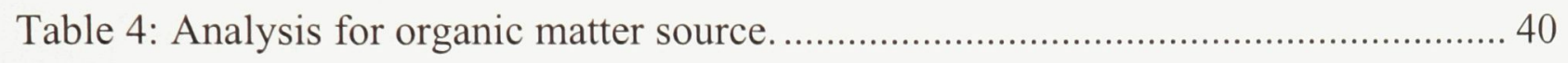




\section{LIST OF FIGURES}

Figure 1: Locations of the study area. (A) Regional map indicating locations of Well 634-30-8W4 (black dot) Youngstown, Albert and Vermilion River (black triangle) Dauphin Manitoba. (B) Detail map of Vermilion River sections VR1 and VR2 along the Manitoba escarpment (modified after McNeil and Caldwell 1981)......... 4

Figure 2: Stratigraphic nomenclature of Upper Cretaceous strata in the Western Canada Sedimentary Basin (WCSB) and WIS. Nomenclature for column 1 after Keller and Pardo (2004); column 2 modified from Simons et al. (2003) and column $3 \& 4$ after McNeil and Caldwell (1981). Units in yellow and green are studied in this project. 5

Figure 3: Outcrop photograph of the Vermilion River section VR2, showing the positions and thickness of the bentonites. (A) B1 is about $9 \mathrm{~cm}$, (B) B2 is about $10 \mathrm{~cm}(\mathrm{C}) \mathrm{B} 3$ is about $12 \mathrm{~cm}$ (D) B4-6 are 3 thin bentonites of about $1-2 \mathrm{~cm}$ (E) B7 is about 10 $\mathrm{cm}$ and $(\mathrm{F}) \mathrm{B} 8$ is about $4 \mathrm{~cm}$.

Figure 4: SEM image of planktonic foraminifera of the general Hedbergella (from Prokoph, 2001), showing the well-preserved outer morphology and no cement filling of the specimens implying no/low diagenetic overprint. 13

Figure 5: Measured section VR1 along the Vermilion River by Prokoph et al. (2000). The four bentonites (C, D, E and F) studied in particular are in yellow. 16

Figure 6: Measured section at VR2 along the Vermilion River indicating the positions as well as the changes across the bentonites. The five bentonites (B, C, D, E and F) studied in particular are in yellow.

Figure 7: Cross plot of $\delta^{18} \mathrm{O}$ for Heterohelix and Hedbergella sp. showing a significant correlation. 21

Figure 8: Measured section of the core from well 6-34-30-8w4 (Youngstown). Data are from Prokoph et al. (2000) and this study. The two bentonites (A and D) with highresolution sampling across the bentonites are in yellow. 23

Figure 9: Dispersion diagrams of $\delta^{18} \mathrm{O}$ versus $\delta^{13} \mathrm{C}$ values for (A) Heterohelix sp., (B) Hedbergella sp. and (C) inoceramid prisms. 25

Figure 10: Changes in trend across bentonites vs. bentonite thicknesses in the Vermilion River sections VR1 and VR2. Note that bentonite-thickness trends are high in A, low in $\mathrm{B}$ and $\mathrm{D}$, and very low in $\mathrm{C}$. 28 
Figure 11: Change in trends vs. bentonite thicknesses in the Vermilion River sections VR1 and VR2. Note that $\Delta \mathrm{C} / \mathrm{N}, \Delta \mathrm{TOC}$ and $\Delta \delta^{13} \mathrm{C}_{\text {org }}$ all shows high correlation with bentonite thickness especially with the exclusion of the very thin bentonite.

Figure 12: Environmental recovery for bentonite C from Vermilion River section VR2. The recovery is $\sim$ sedimentation thickness above bentonite/Sedimentation rate $(0.08 \mathrm{~m} / \mathrm{cm} / \mathrm{kyr})=0.08 * 100 \mathrm{kyr}=8 \mathrm{kyr}$.

Figure 13: Recovery at bentonite D from Vermilion River section VR2. Recovery $0.12 \mathrm{~m} / \mathrm{cm} / \mathrm{kyr}=12 \mathrm{kyr}$. 33

Figure 14: Recovery at bentonite E from Vermilion River section VR2. Recovery $0.18 \mathrm{~m} / \mathrm{cm} / \mathrm{kyr}=18 \mathrm{kyr}$. 34

Figure 15: Recovery at bentonite F from Vermilion River section VR2. Recovery $0.16 \mathrm{~m} / \mathrm{cm} / \mathrm{kyr}=16 \mathrm{kyr}$. 35

Figure 16: Synthesis Chemostratigraphic correlation between the Cenomanian-Turonian sections VR1, VR2, core 6-34-30-8W4 and the section from Pueblo, Colorado, USA (after Keller and Pardo, 2004). Age calculated from Barker et al. 2009 36

Figure 17: Generalized $\mathrm{C} / \mathrm{N}$ ratio vs. carbon isotopic (top) and nitrogen isotopic vs. carbon isotopic (bottom) compositions of organic matter, showing the data from this study plotting in the field of C3 land plants (after Meyers, 1994; 2009) 41 


\section{LIST OF PLATES}

Plate 1: Light-microscope image of residue samples across bentonite D from Vermilion River section V1. The residue consists of spores (S), inoceramid prisms (I) and some planktonic foraminiferal, mostly Heterohelix (H') and some Hedbergella sp. (H) below the bentonite. The foraminifera are well preserved and the noticeable changes is the reduced number of Hedbergella sp. in plates S19 \& S19' immediately above bentonite D.

Plate 2: Light-microscope image of residue samples across bentonite $\mathrm{E}$ from Vermilion River section V1. The residue contain fish remains (F) and some planktonic foraminiferal, mostly Heterohelix sp. ( $\left.\mathrm{H}^{\prime}\right)$ below the bentonite and some Hedbergella sp. (H) at S14 and 15'. The foraminifera are well preserved, but no changes are discernible across the bentonite except the first appearance of the star shaped foraminifera 'SF' at S16. 68

Plate 3: Light-microscope image of residue samples across bentonite $\mathrm{F}$ from Vermilion River section V1. The residue is dominated by inoceramid prisms (I), some fish remains $(\mathrm{F})$ but devoid of planktonic foraminiferal shells. The inoceramid prisms are well preserved, but no changes are discernible across the bentonite.

Plate 4: Light-microscope image of residue samples across bentonite A from Vermilion River section V2. The residue is dominated by selenite crystals (Se) and some spores (S), but devoid of inoceramid prisms or planktonic foraminiferal. 70

Plate 5: Light-microscope image of residue samples across bentonite B from Vermilion River section V2. The residue consists of fish remains (F), biotite (B), spores (S) and some planktonic foraminifera. The noticeable change across the bentonite is the sudden appearance of Heterohelix sp. (H') in B and abundance of fish remains at C and $\mathrm{C}^{\prime}$. 71

Plate 6: Light-microscope image of residue samples across bentonite $\mathrm{C}$ from Vermilion River section V2. The residue consists of fish remains (F), few inoceramid prisms (I) and some planktonic foraminiferal, both Heterohelix (H') and Hedbergella sp. (H) below the bentonite. The foraminifera are well preserved and the noticeable change across the bentonite is the reduction in Hedbergella sp. abundance at B. .. 72

Plate 7: Light-microscope image of residue samples across bentonite D from Vermilion River section V2. The residue consists of fish remains (F), some spores (S), inoceramid prisms (I) and some planktonic foraminiferal, mostly Heterohelix (H') and some Hedbergella sp. $(\mathrm{H})$ below the bentonite. The Heterohelix sp. Shows a 
slight size changes across the bentonite while Hedbergella sp. disappear in B \& B' above bentonite $\mathrm{D}$.

Plate 8: Light-microscope image of residue samples across bentonite $\mathrm{E}$ from Vermilion River section V2. The residue consists of some inoceramid prisms (I), few fish remains $(\mathrm{F})$ and some planktonic foraminiferal, mostly Hedbergella $(\mathrm{H})$ and some Heterohelix sp. (H') below the bentonite. The Heterohelix sp. shows a slight size decrease across the bentonite and later increase abundance. 74

Plate 9: Light-microscope image of residue samples across bentonite $\mathrm{F}$ from Vermilion River section V2. The residue consists of mostly inoceramids prisms (I) and some planktonic foraminiferal, mostly Heterohelix (H') and some Hedbergella sp. $(\mathrm{H})$ below the bentonite. The Hedbergella sp. shows a slight size changes across the bentonite.

Plate 10: Light-microscope image of residue samples across bentonite B from well 6-3430-8w4 (Youngstown). The residue consists of some spores (S) and planktonic foraminifera, mostly Heterohelix $\left(\mathrm{H}^{\prime}\right)$ and some Hedbergella sp. $(\mathrm{H})$ below the bentonite. The sizes of both Heterohelix and Hedbergella sp. become slightly bigger across the bentonite. 76

Plate 11: Light-microscope image of residue samples across bentonite A from well 6-3430-8w4 (Youngstown). The residue consists of some fish remains (F), biotite (B), inoceramid prisms (I) and some planktonic foraminifera, mostly Heterohelix ( $\left.\mathrm{H}^{\prime}\right)$ and some Hedbergella sp. (H) below the bentonite. The sizes of Heterohelix sp. initially become smaller across the bentonite, and then become slightly bigger afterwards.

Plate 12: Light-microscope image of residue samples across bentonite in Morden Fm from well 6-34-30-8w4 (Youngstown). The residue consists of mostly inoceramid prisms (I) and devoid of any foraminifera. 78 


\section{LIST OF APPENDICES}

Appendix A 1: Geochemical data table for Vermilion River V1. Data originally acquired by Prokoph, 2001 except those with gray background acquired in this study......... 60

Appendix A 2: Geochemical data table for Vermilion River V2 …................................. 61

Appendix A 3: Geochemical data table for Vermilion River V2 (Continuation).............. 63

Appendix A 4: Geochemical data table for well 6-34-30-8w4 (Youngstown). Data originally acquired by Prokoph, 2001 except those with green background acquired in this study 64

Appendix A 5: Changes across bentonites using other geochemical data. 66 


\section{INTRODUCTION}

Large volcanic eruptions of igneous provinces (LIP) have been recognised for several years as a possible cause of mass extinctions and other environmental perturbations in Earth's history, including hypothetical 'volcanic winters' (e.g., Stothers, 1993; Rampino and Self, 1993a). The age uncertainties of LIP's has led to controversy over the shortterm $(<20,000$ years) environmental consequences of these events (e.g., Kerr, 1998; Prokoph et al., 2001; Berner, 2002). The similar explosive eruptions characteristic of island arc type volcanism are generally smaller than LIP eruption, but more frequent, and have been attributed to causing the onset short-term climatic cooling events (e.g., Rampino and Self, 1992).

Massive volcanic eruptions pose both short-term and long-term consequences on the environment, through the introduction of carbon dioxide, sulfur and volcanic ash to the atmosphere, which would significantly alter the atmosphere carbon and sulfur cycle, cloud-cover, heat-penetration, and thus strongly influence the annual temperature and acidity of rainfall (Kauffman, 1975). Over 600 volcanic eruptions are recorded in the middle and Upper Cretaceous marine strata of the Western Interior in the form of $0.1 \mathrm{~cm}$ - 3 m thick ash layers and ash-sediment mixtures (bentonites) (Kauffman, 1984; Rampino and Self, 1993b).

The effects of volcanism in creating biotic stress and mass extinction remain largely uncertain (Benton and Twitchett, 2003, Keller, 2003, Tantawy et al. 2009). Climate modelers have suggested mechanisms as to how global warming could reduce ocean circulation and the amount of dissolved oxygen to create benthic anoxia (Hotinski, et al. 
2001). The environmental recovery in the Cretaceous ocean in the aftermath of largescale volcanic events is generally characterized by the dominance of disaster opportunists such as the planktic foraminiferal species, Guembelitria cretacea (Keller, 2003), dwarfed low oxygen tolerant Heterohelix species and the presence of a few small species of Hedbergella and Globigerinelloides (Tantawy et al. 2009).

The Cenomanian-Turonian $(\mathrm{C}-\mathrm{T})$ boundary interval is a classic example of an Oceanic Anoxic Event (OAE), because of the development of worldwide organic carbon-rich marine deposits, with a correlatable positive shift in carbon-isotope values in marine carbonate and terrestrial organic matter (e.g. Arthur et al. 1988; Hasegawa 1997). This positive $\delta^{13} \mathrm{C}$ shift is conventionally related to excess burial of organic carbon (Jenkyns 1980; Scholle and Arthur 1980; Schlanger et al. 1987).

The application of an integrated geochemical and micropaleontological approach is an essential part of marine paleoenvironmental analysis in these Cretaceous sediments (e.g. Leckie et al., 2002). Geochemical evidence provides clues concerning the nature of the environmental changes at the boundary of volcanic eruption while micropaleontological proxies provide clues on stratigraphy, chronological correlation of climatic events and reconstruction of the paleotemperature.

This research entails a quantitative high-resolution $(<1000$ years/sample interval) analysis to recognize any trends observable in sedimentary and/or paleontological records in the sequences deposited before and in the aftermath of large Upper Cretaceous volcanic eruptions within the Western Canadian Sedimentary Basin. The study focuses on the sediments of the Cenomanian to Turonian Belle Fourche Member of the Ashville Formation, the Keld members of the Favel Formation within the Manitoba escarpment 
(Figure 1) and the Second White Specks Formation and Belle Fourche Formation of the Central Plains of Alberta (Figure 2).

No previous integrated micropaleontological/geochemical study has previously been carried out on environmental changes across Cretaceous bentonites, except for a single study in Italy using only fossil assemblage changes (e.g., Galeotti et al. 2002). The objectives of this study are thus;

- to recognize any trends observable in sedimentary and/or paleontological records across the bentonites, using quantitative high-resolution $(<1000$ years/sample interval)

- to determine the relationship between volcanism, paleoclimate and paleoenvironment.

In this study, foraminifera and inoceramid prisms composed of low Mg-calcite, thus potential paleotemperature archives, were utilised. The oxygen and carbon-isotope $\left(\mathrm{C}_{\text {org }}\right.$ and $\mathrm{C}_{\text {carb }}$ ), TOC, $\mathrm{C} / \mathrm{N}, \delta^{15} \mathrm{~N}$ and fossil assemblage changes observed in two outcrops and a drill-core section spanning several bentonite intervals and the Cenomanian-Turonian (C-T) boundary are studied. A high-resolution total organic carbon (TOC) and stable isotope data from foraminiferal specimens, inoceramid prisms and bulk-rock sample in all the sections have been obtained on a centimeter scale. The carbon-isotope curves are also compared with the carbon isotope record from Pueblo Colorado, USA (Keller and Pardo, 2004). 


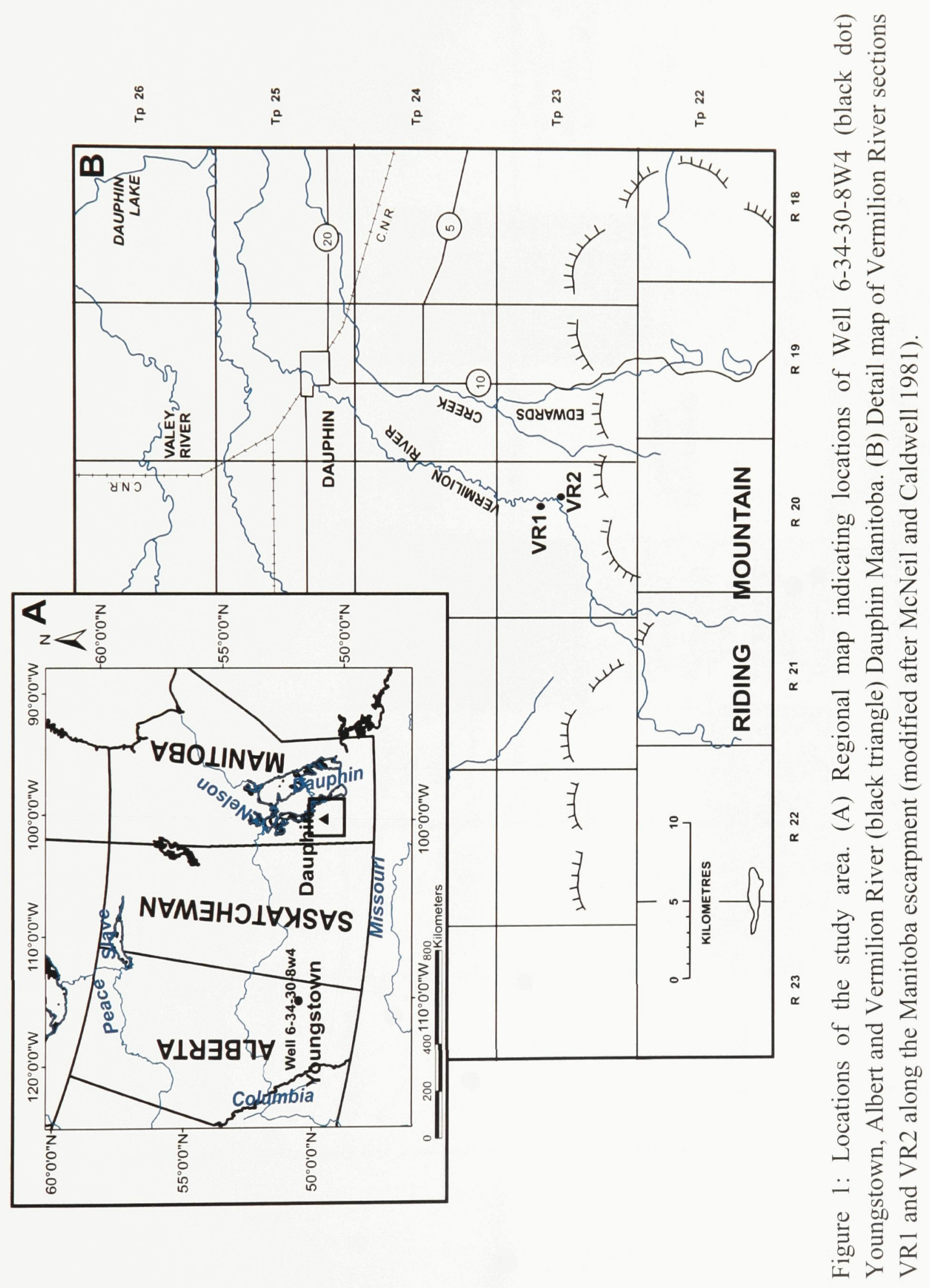




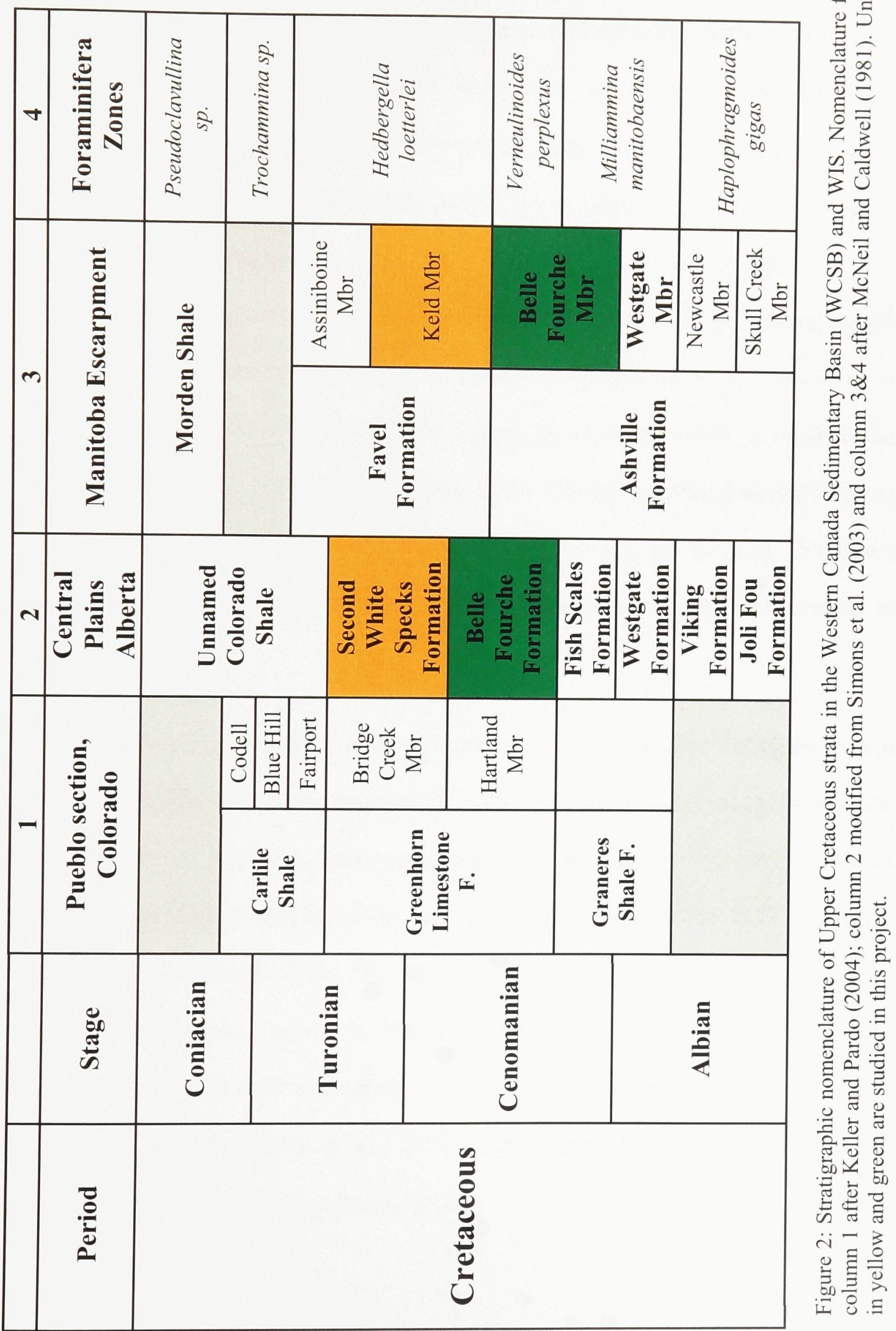




\section{Previous Work in the WCSB/WIS}

Previous work in the WCSB includes a regional syntheses by Caldwell (1984) and Williams and Burke (1964), detailed description of the lithostratigraphic and micropaleontological aspects within the Manitoba Escarpment by McNeil and Caldwell (1981) and McNeil (1984), and detailed lithological descriptions by Simpson (1982). A comprehensive lithostratigraphy of the Upper Cretaceous strata of the Alberta foothills and British Columbia was provided by Stott $(1963,1967$, and 1982). The biostratigraphic zonation of Cretaceous strata in Western Canada was synthesized by Caldwell et al. (1978). More recent research includes an organic geochemical study of CenomanianTuronian sediments by Simons et al. (2003), a new lithostratigraphic framework for the Cretaceous Colorado Group in the Cold Lake heavy oil area by Tu et al. (2007), and paleoenvironmental studies in the southern Alberta and southwestern Saskatchewan by Nielsen et al. (2008).

The Colorado/Alberta Group consists predominantly of mudstone interspersed with relatively thin sandstone and conglomerate beds. Other minor lithotypes include shalychalky limestone, bentonite, pelecypod coquinas, horizons of fish debris, nodular phosphorite, as well as siderite, calcite and pyrite concretions (Leckie et al. 1994). The stratigraphic terminology of the Colorado Group, (Figure 2), varies from province to province and between regions in the provinces. Since the Colorado Group is a predominantly marine shale succession, it has been well constrained biostratigraphically using foraminifera (Caldwell et al., 1978; McNeil and Caldwell, 1981), ammonites (Jeletzky, 1971) and microflora (Singh, 1983). 
In contrast to the extensive range of biostratigraphic and sedimentary studies, stable isotope studies in the WSCB are only a few and local, restricted to the C-T interval (Kyser et al. 1993; Prokoph et al. 2001; Bloch et al. 1999).

The Albian to Santonian Colorado Group was deposited within an approximately 25-30 million year period, which encompasses the Greenhorn and Niobrara sea-level cycles (Kauffman, 1984; Tu et al., 2007). Global sea level through this period was high, with peaks in the Late Albian, Early Turonian, and Middle Santonian (Haq et al, 1987) and was coincident with a generally warm equable Mid-Cretaceous climate (Barron, 1983). At times of high global sea level, warm Tethyan-derived water mixed with cooler Boreal water resulted in a shallow epeiric seaway from the Gulf of Mexico to the Arctic (Leckie et al. 1994). Global sea level changes were overprinted by a complex of regional fluctuations caused by Cordilleran tectonics.

Bentonites beds are abundant and widespread in upper Mesozoic strata of the western interior, particularly those of Late Cretaceous age (e.g., Gill and Cobban, 1973; Kauffman, 1984). These bentonites contain igneous minerals, such as biotite and sanidine that have been widely used for radiogenic-isotope dating (Obradovich and Cobban, 1975; Elder, 1988).

Bentonites thus provide an important means for determining the timing of volcanic events in the western Cordilleran orogenic belt (Obradovitch and Cobban 1975; Villeneuve et al. 1993; Prokoph et al. 2001). They also supply important alternative data on pluton emplacement histories that can be integrated with dates obtained directly from deeper parts of the Sierra Nevada batholith. Regional studies of western interior bentonite 
distributions, thicknesses, and crystal-size distributions have been used to determine volcanic source areas and wind patterns during other Cretaceous time intervals (e.g., Knechtel and Patterson, 1956, 1962; Slaughter and Earley, 1965; Amajor, 1985; Collins, 1987; Nichols et al., 1987).

There is evidence that sea floor chemistry and biofacies changed after a series of volcanic events in the Western Interior Seaway (WIS), but time-scale resolution has been too low to determine which sedimentary and biotic patterns are consequences of this volcanism (e.g., Prokoph et al., 2001, Bloch et al., 1999, Desmares et al., 2002, Fisher and Arthur, 2002). Thus, the interaction of volcanic events with other environmental factors (e.g., relative sea-level changes, water circulation changes, Milankovitch-cycle driven climate change) on sedimentary and biotic pattern formation (e.g., sea-floor redox cycles or extinction events) remains questionable.

\section{Regional Geological Setting}

The Western Canada Sedimentary Basin (WCSB) comprises the eastern Canadian Cordillera and two major sedimentary basins: a northwest-trending trough in front of the Cordilleran Fold and Thrust Belt (extending eastward to the Canadian Shield) called the Alberta Basin; and the cratonic Williston Basin, centered in North Dakota and extending into southern Saskatchewan and southwest Manitoba. Studied outcrops in the Riding Mountain, located southwest of Dauphin, on the Manitoba Escarpment, host exposed sediments of the Cenomanian to Campanian: Belle Fourche Member of the Ashville Formation, the Keld and Assiniboine members of the Favel Formation, the lower Morden Shale (Figure 2) and the Niobrara Formation overlain by the lower Pierre Shale. Core 
section 6-34-30-8W4 at Youngstown consists of claystones and marlstone spanning C-T boundary interval completely (Schroeder-Adams et al. 1996, Prokoph et al. 2001).

There were ten major transgressive-regressive marine cycles during the Cretaceous period in the WIS/WSCB, (Kauffman, 1977, 1984). The transgressive-regressive cycles were partly controlled by eustasy; their records are preserved in strata deposited in the deep-sea, continental margin and epicontinental seas. Study of the isotopic composition of the tests of Cretaceous foraminifers and nannofossils from deep cores and outcrop sections indicate that the Cretaceous open oceans cooled slowly toward the end of Mesozoic era, with temperature maxima occurring in the Albian, Cenomanian and Coniacian-Santonian stages (Lowenstam and Epstein, 1954, Coplen and Schlanger, 1974; Douglas and Savin, 1975). The stratigraphic interval studied is part of the Greenhorn cycle with maximum sea-level assumed to have occurred during the early Turonian (Kauffman and Caldwell, 1994). 


\section{MATERIALS AND METHODS}

Two sections VR1 and VR2 along the Vermilion River (southwest of Dauphin, Manitoba) and a core from well 6-34-30-8w4 (Youngstown), spanning the C-T boundary and several bentonites intervals were selected for this investigation. The Vermilion River section (VR1) and the core were logged, sampled and analysed by Prokoph and parts of these analysis were published in Prokoph et al. (2000) and Karboshewski (2006). However, some additional samples and/or previously unanalyzed fossil components (e.g., Heterohelix) were analyzed herein to further improve the resolution archived in these records.

The VR1 section is located on the west bank of the Vermilion River, approximately 16.4 $\mathrm{km}$ southwest of Dauphin, Manitoba, while VR2 is located on a tributary along the east bank of Vermilion River, approximately $17.5 \mathrm{~km}$ southwest of Dauphin (Figure 1). The bentonites occurring in the outcrops were identified, and their thicknesses measured and documented (Figure 3). Eleven samples from VR1 and 27 samples from VR2 were collected from the sections, mostly with 3 samples from $1-10 \mathrm{~cm}$ above and one sample just below each of the selected bentonite layers. A set of 15 core samples from well 6-3430-8w4 (Youngstown) was also taken in close proximity to the bentonites and was processed for paleontological and isotope analysis, from which 73 picked samples of Heterohelix sp., Hedbergella sp., and inoceramid prisms were analyzed for stable isotopes, elemental composition and TOC.

Foraminifera were separated from the sediment following the standard method of Keller et al. (1995). Samples were crushed, soaked in a 5\% hydrogen peroxide solution and left to stand for about 5 to 18 hours to disaggregate. The disaggregated sediment components 

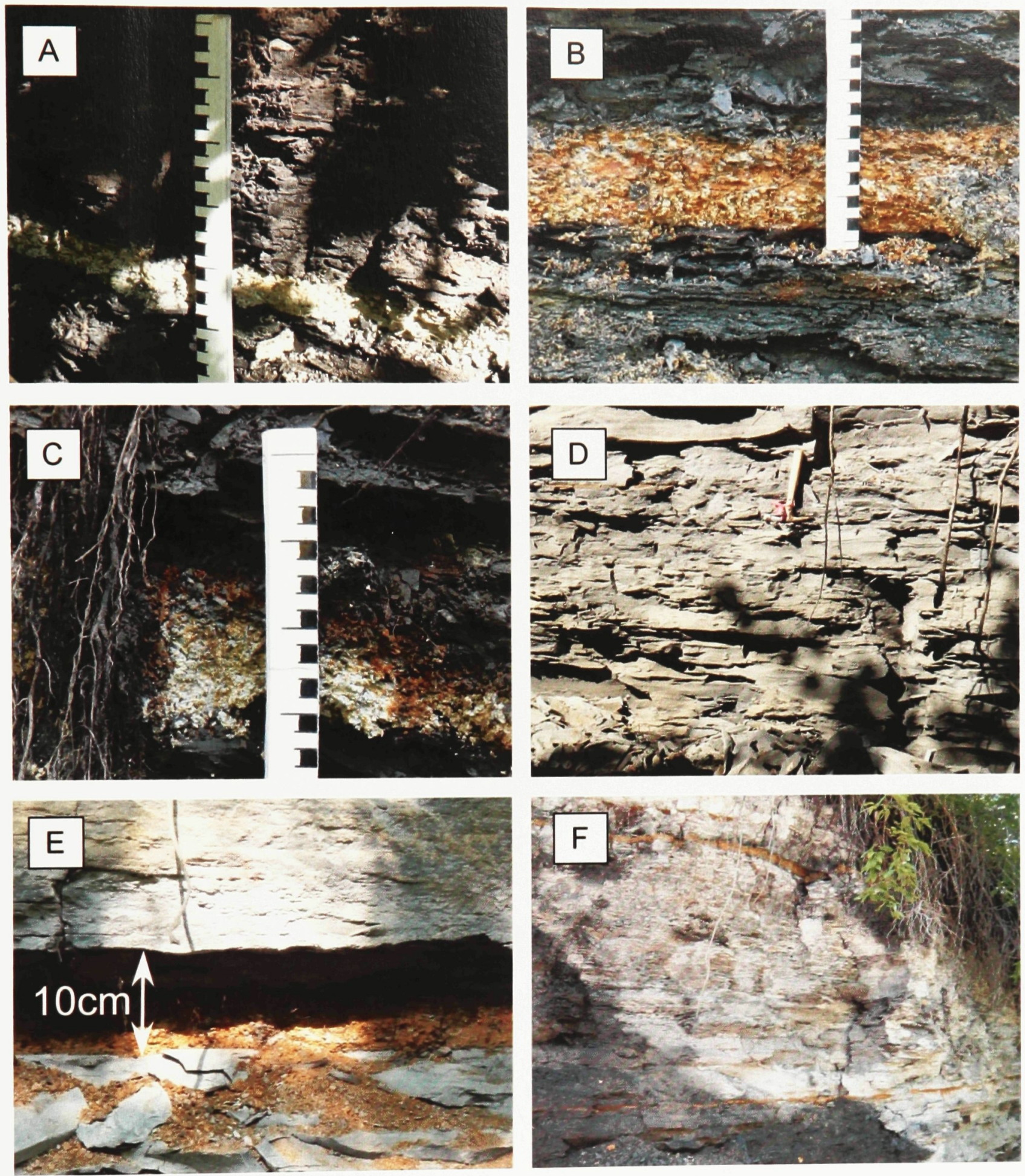

Figure 3: Outcrop photograph of the Vermilion River section VR2, showing the positions and thickness of the bentonites. (A) B1 is about $9 \mathrm{~cm}$, (B) B2 is about $10 \mathrm{~cm}$ (C) B3 is about $12 \mathrm{~cm}$ (D) B4-6 are 3 thin bentonites of about $1-2 \mathrm{~cm}(\mathrm{E}) \mathrm{B} 7$ is about $10 \mathrm{~cm}$ and (F) B8 is about $4 \mathrm{~cm}$. 
were washed through a 63 micron sieve until the liquid coming through the sieve is clean. The residue sample was then air dried and transferred into labeled vials for storage.

Processed samples were sprinkled sparsely across a gridded brass picking tray (with holes for easy picking) and scanned under a binocular microscope with reflected light. Foraminifera preserved in the sediment were typically picked out using magnification of $30 \mathrm{X}$ to $40 \mathrm{X}$. Ultrasonic treatment was used to clean specimens after picking.

Only foraminiferal specimens without evidence of any obvious diagenetic overprint (e.g. cement infilling) were selected for analysis (Figure 4). Selected foraminiferal specimens and inoceramid prisms were analysed for stable isotope ratios $\left({ }^{18} \mathrm{C}\right.$ and $\left.{ }^{13} \mathrm{O}\right)$, whereas bulk-rock samples were analyzed for elemental (NCHS) composition, Carbon-organic isotope ratio, ${ }^{15} \mathrm{~N}$ and total organic carbon (TOC) using standard analytical techniques at the G.G. Hatch Stable Isotope Laboratory, University of Ottawa. For the bulk-rock analyses, samples were powdered and decarbonatized with $5 \% \mathrm{HCl}$ for $24 \mathrm{hrs}$, rinsed and dried.

Samples for stable isotope $\left({ }^{18} \mathrm{O}\right.$ and $\left.{ }^{13} \mathrm{C}\right)$ analysis were weighed, Helium-flushed and allowed to react with $0.1 \mathrm{~mL}$ of $\mathrm{H}_{3} \mathrm{PO}_{4}$ at $25^{\circ} \mathrm{C}$ for $24 \mathrm{hrs}$. Isotopic measurements were carried out using a Delta XP and a Gas Bench II, both from Thermo Finnigan. Results were reported in $\delta$ notation against the VPDB standard and an analytical precision is $+/$ $0.1 \%$.

Values of wt. \% of N, H, S and TOC were determined using decarbonatized powdered samples. Samples were weighed into tin capsules and loaded with standards into a Vario EL III elemental analyser manufactured by "Elementar", Germany. Samples were flash 


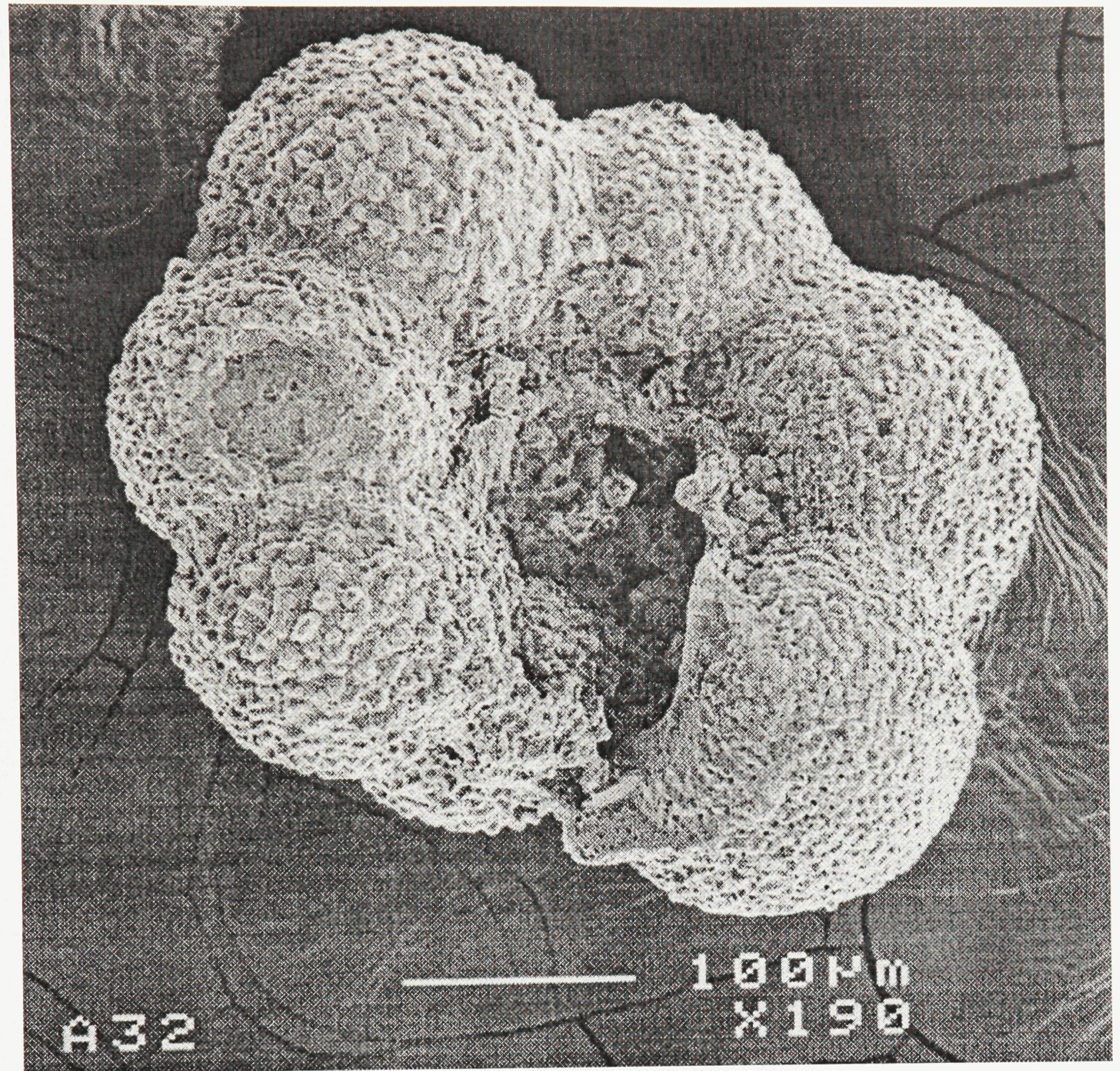

Figure 4: SEM image of planktonic foraminifera of the general Hedbergella (from Prokoph, 2001), showing the well-preserved outer morphology and no cement filling of the specimens implying no/low diagenetic overprint. 
combusted with oxygen at about $1800^{\circ} \mathrm{C}$ and carried by helium through columns of reducing/oxidizing chemicals to get $\mathrm{N}_{2}, \mathrm{CO}_{2}, \mathrm{H}_{2} \mathrm{O}$ and $\mathrm{SO}_{2}$. The gases are separated by "purge and trap" of specific adsorption columns so that the TCD (thermal conductivity detector) could detect each gas separately. The routine analytical precision was $+/-0.1 \%$ (G.G. Hatch Isotope Laboratory, 2010).

Isotopic ratios for ${ }^{13} \mathrm{C}_{\text {org }}$ and ${ }^{15} \mathrm{~N}$ were determined using decarbonatized powdered samples. Samples and standards were weighed into tin capsules and loaded into an elemental analyser interfaced to an Isotope Ratio Mass Spectrometer (IRMS). Sample/Standard is flash combusted at about $1800^{\circ} \mathrm{C}$ (Dumas combustion) and the resulted gas products carried by helium through columns of oxidizing/reducing chemicals optimised for $\mathrm{CO} 2$ and N2. The gases are separated by a "purge and trap" adsorption column and sent to (IRMS) interface. 


\section{RESULTS}

\section{Vermilion River Outcrop Section VR1}

The section is about $18 \mathrm{~m}$ thick consisting from bottom to top of shale/claystone with an associated bentonite, considered to be correlating to the " $\mathrm{X}$ " bentonite of the Belle Fourche Formation. This unit is overlain by a pyrite-rich shale/claystone, which gradually changes to marlstone of the Keld Member of Favel Formation. The Keld Member in turn hosts several bentonites of less than $3 \mathrm{~cm}$ to $10 \mathrm{~cm}$ thickness. Carbonate content generally increases to the top of the section (Figure 5).

Planktic foraminifera are rare from the base of the section but become common within the Keld Member, consisting primarily of Heterohelix sp. and Hedbergella sp. with Heterohelix sp. being predominant.

\section{Stable isotope and TOC}

The $\delta^{13} \mathrm{C}, \delta^{13} \mathrm{C}_{\text {org }}$ and $\delta^{18} \mathrm{O}$ values through the sections show both short- and long-term variation, with short-term variations mostly occurring across the bentonites in response to volcanism. Variations in $\delta^{13} \mathrm{C}$ and $\delta^{18} \mathrm{O}$ values of calcite with depth are plotted and presented in Figure 5. Stable isotope data are scarce at the bottom of the sections, because foraminifera were absent in these intervals.

The $\delta^{13} \mathrm{C}$ values range between $-5.58 \%$ and $2.77 \%$, with a general enrichment towards the top of the section. The highest value occurs at $2.5 \mathrm{~m}$ depth, close to the $\mathrm{L}$. Cenomanian - E. Turonian boundary, while the lowest value occurs at $10.55 \mathrm{~m}$ depth, in the mid L. Cenomanian. The $\delta^{13} \mathrm{C}$ values fluctuate at high frequency especially across the bentonite intervals about $1.5 \mathrm{~m}(10-11.5$ 


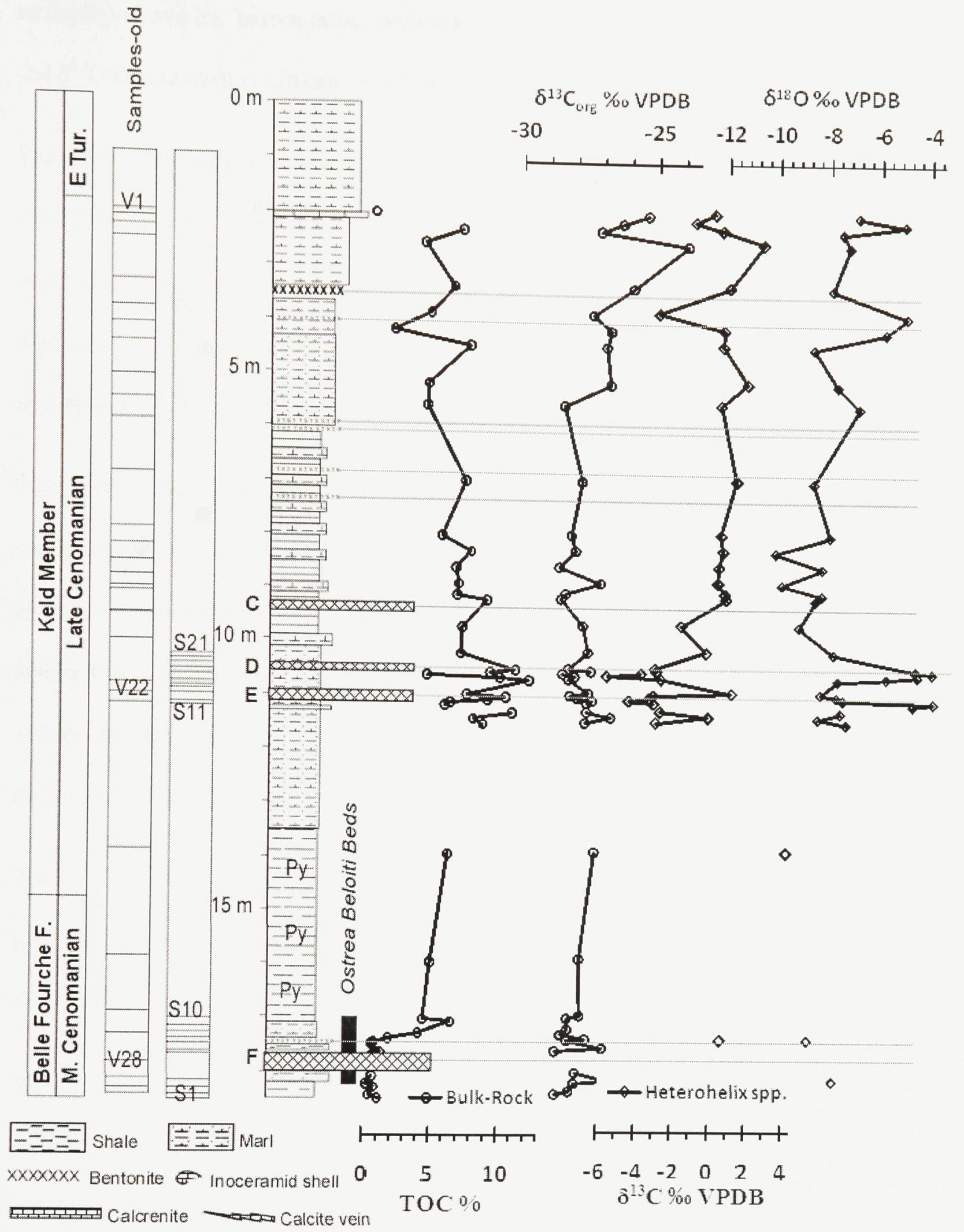

Figure 5: Measured section VR1 along the Vermilion River by Prokoph et al. (2000). The four bentonites $(\mathrm{C}, \mathrm{D}, \mathrm{E}$ and $\mathrm{F})$ studied in particular are in yellow. 
$\mathrm{m}$ depth) above the barren zone. Above this high frequency interval, about $10.5 \mathrm{~m}$ depth, the $\delta^{13} \mathrm{C}$ values shift positively by about $4-4.5 \%$.

The $\delta^{18} \mathrm{O}$ value ranges between $-10.08 \%$ to $-3.77 \%$, with a general depletion towards the top of the section. The most negative value occurs at $8.2 \mathrm{~m}$ depth in the late Cenomanian while the highest value occurs at $11 \mathrm{~m}$ depth, also in the late Cenomanian. There is a highresolution frequency isotope fluctuation in the interval between $10-11.5 \mathrm{~m}$ depth. For example the $\delta^{18} \mathrm{O}$ values shift negatively by about $4-5 \%$ at about $10.5 \mathrm{~m}$ depth.

The $\delta^{13} \mathrm{C}_{\text {org }}$ value ranges from $-28.68 \%$ to $-23.94 \%$, with the most negative value occurring at $17.5 \mathrm{~m}$ depth within mid-Cenomanian Belle Fourche F. and the highest vale at $2.5 \mathrm{~m}$ depth towards the Early Turonian boundary. The $\delta^{13} \mathrm{C}_{\text {org }}$ values are relatively stable from the bottom of the section till about $10.5 \mathrm{~m}$ depth, only slightly fluctuating across the bentonites intervals. Above this relatively stable interval, the $\delta^{13} \mathrm{C}_{\text {org }}$ values shift negatively by $1-1.5 \%$ till the end of Late Cenomanian when it becomes heavier.

The TOC at the bottom of the section between $17.3-18.3 \mathrm{~m}$ depth has the lowest values, generally $<1.5 \%$. The TOC increases to $\sim 5 \%$ at $17 \mathrm{~m}$ depth and further increases to about $11 \%$ at $10.5 \mathrm{~m}$ depth, which gradually drops to $<1 \%$ towards the Early Turonian.

The overall general trends displayed by both the stable isotopes and the TOC are fairly stable values from the bottom of the section to about $10-11 \mathrm{~m}$ depth where is a simultaneous positive inflexion for $\left(\delta^{13} \mathrm{C}\right.$ and TOC) and negative inflexion for $\left(\delta^{13} \mathrm{C}_{\mathrm{org}}\right.$ and $\left.\delta^{18} \mathrm{O}\right)$. Towards the Early Turonian the relative values for $\left(\delta^{13} \mathrm{C} / \mathrm{TOC}\right)$ and $\left(\delta^{13} \mathrm{C}_{\mathrm{org}}\right.$ $\left./ \delta^{18} \mathrm{O}\right)$ return to nearly the same ratios as observed prior to the inflexions. 


\section{Vermilion River Outcrop Section VR2}

The Vermilion River outcrop section VR2 is about $12 \mathrm{~m}$ thick consisting from bottom to top of; (1) dark gray laminated shale with an intercalated bentonite of about $10 \mathrm{~cm}$ within the Belle Fourche Formation, which gradually changes to (2) marlstone of the Keld Member of the Favel Formation, with several interbedded bentonites of about $1 \mathrm{~cm}$ to $12 \mathrm{~cm}$ thickness. Carbonate content generally increases toward the top of the section (Figure 6).

Planktic foraminifera are absent from the base of the section until about $1.72 \mathrm{~m}$ with the first encounter of Hedbergella sp. They become common within the Keld member with Heterohelix sp. being predominant. Inoceramid prisms are absent from the base until about $2.64 \mathrm{~m}$ depth and are noticeably absent within the $5.92-5.96 \mathrm{~m}$ interval. All $\delta^{13} \mathrm{C}$ and $\delta^{18} \mathrm{O}$ data of carbonates are calibrated to the V-PDB standard.

\section{Stable isotope and TOC}

The $\delta^{13} \mathrm{C}$ and $\delta^{18} \mathrm{O}$ values for Heterohelix sp., Hedbergella sp. as well as inoceramid prisms show similar variability as observed in the VR1 section, with short-term variations mostly occurring across the bentonites in response to volcanism. Though the $\delta^{18} \mathrm{O}$ values for inoceramid, Heterohelix and Hedbergella are generally similar, inoceramid is most depleted in $\delta^{18} \mathrm{O}$. Of the planktic foraminifera, the Heterohelix have most depleted $\delta^{18} \mathrm{O}$ values while Hedbergella generally has slightly less depleted values at similar sampling depth. For $\delta^{13} \mathrm{C}$ however, the inoceramids are unexpectedly most enriched, while Heterohelix is slightly more enriched in $\delta^{13} \mathrm{C}$ values than Hedbergella.

Variations in $\delta^{13} \mathrm{C}, \delta^{18} \mathrm{O}, \delta^{13} \mathrm{C}_{\mathrm{org}}$ and TOC values with depth are plotted and presented in 


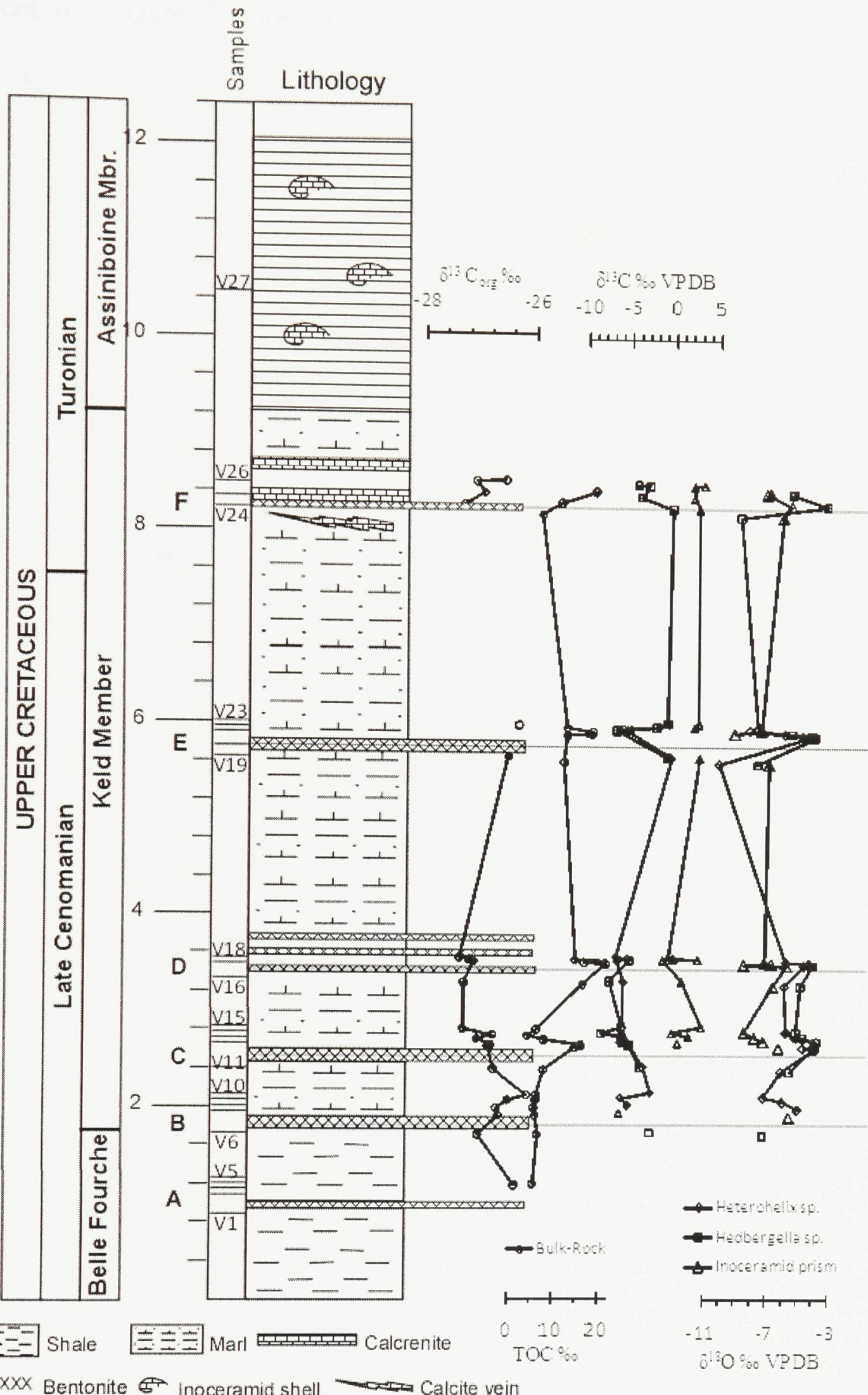

$\times \times \times \times \times \times x$ Bentonite Inoceramid shell calcite vein

Figure 6: Measured section at VR2 along the Vermilion River indicating the positions as well as the changes across the bentonites. The five bentonites $(\mathrm{B}, \mathrm{C}, \mathrm{D}, \mathrm{E}$ and $\mathrm{F})$ studied in particular are in yellow. 
Figure 6. Figure 7 shows a perfect correlation between $\delta^{18} \mathrm{O}$ for Heterohelix and Hedbergella sp. and thus complement each other, although Hedbergella sp. are characterized by generally, higher $\delta^{18} \mathrm{O}$ values than Heterohelix sp.

The $\delta^{13} \mathrm{C}$ values for the foraminifers range between $-8.25 \%$ and $-0.29 \%$, while $\delta^{18} \mathrm{O}$ values ranges from $-10.04 \%$ to $-3.76 \%$. There is positive excursion, from the bottom of the section to the top, with $\delta^{13} \mathrm{C}$ values ranging from $\sim 5.5 \%$ to $\sim 0.5 \%$, while $\delta^{18} \mathrm{O}$ values shift negatively from $\sim 5 \%$ to $\sim 9 \%$. The stable isotope ratios measured from the inoceramid prisms show a similar trend, but have an overall $\delta^{13} \mathrm{C}$ enrichment of $\sim 3-4 \%$ o and depletion of up to $2 \%$ in $\delta^{18} \mathrm{O}$ as compared to the planktic foraminifera.

The $\delta^{13} \mathrm{C}_{\text {org }}$ values range from between $-27.37 \%$ to $-26.13 \%$, with the most negative values occurring at $3.56 \mathrm{~m}$ depth and highest value at $2.13 \mathrm{~m}$ depth, both within the LateCenomanian. The $\delta^{13} \mathrm{C}_{\mathrm{org}}$ values fluctuate strongly through the section and even more across the bentonites intervals. There is a relative negative shift in $\delta^{13} \mathrm{C}_{\text {org }}$ values of about $0.6 \%$ at about $2.6 \mathrm{~m}$ depth which later shift positively at about $5.7 \mathrm{~m}$ depth. However these trends are not conspicuous due to the sparse data available.

The TOC values from the bottom of the section to about $2.4 \mathrm{~m}$ depth are fairly constant with values of about $6 \%$, increase to about $15 \%$ at $3.3 \mathrm{~m}$ depth. The TOC values gradually drops back to $\sim 6 \%$ by $8.2 \mathrm{~m}$ depth, which correlates to the Early Turonian boundary.

Though the data are sparse in the section between $3.5-5.6 \mathrm{~m}$ and from $6-8.24 \mathrm{~m}$ depth, the general trend is similar to that observed in the Vermilion River VR1 section. The stable 


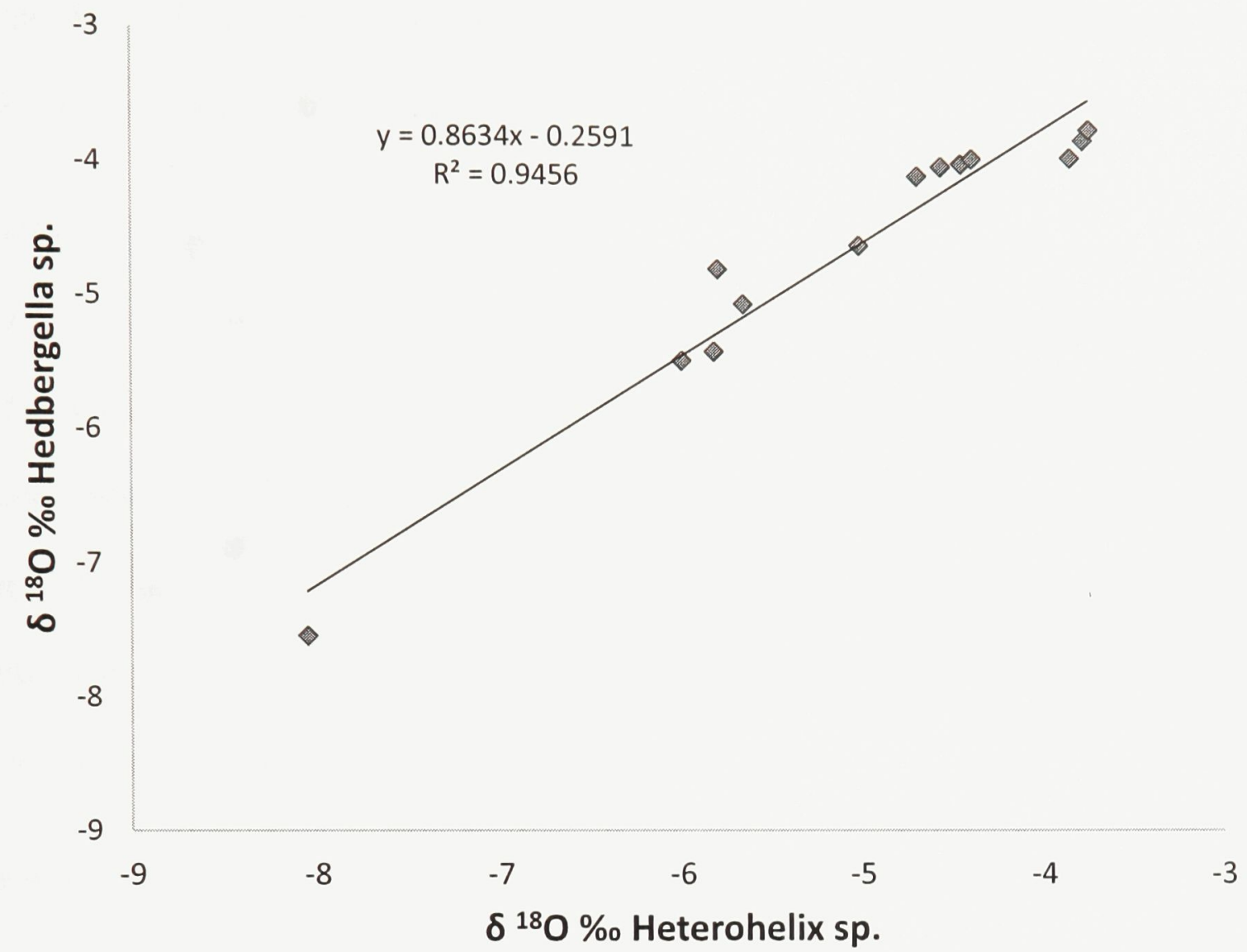

Figure 7: Cross plot of $\delta^{18} \mathrm{O}$ for Heterohelix and Hedbergella sp. showing a significant correlation. 
isotopes and the TOC are fairly constant from the bottom of the section to about $3.5 \mathrm{~m}$ depth where simultaneous positive $\left(\delta^{13} \mathrm{C}\right.$ and TOC) and negative $\left(\delta^{13} \mathrm{C}_{\mathrm{org}}\right.$ and $\left.\delta^{18} \mathrm{O}\right)$ shifts occur. Towards the Early Turonian all records return to isotopic values similar to what was observed prior to the inflexions.

\section{Section 6-34-30-8w4 (Youngstown).}

The $75 \mathrm{~m}$ Youngstown core section from 680-755m depth is comprised of shale/claystone with several interbedded bentonites. The Belle Fourche Formation occurs at the base, the Second White Specks Formation within the upper half of the section, and claystone of the Upper Colorado Shale at the top. The "X" bentonite occurs at about $744 \mathrm{~m}$ depth. Carbonate content increases to the top of the section with highest values in the Second White Specks Formation (Figure 8).

Planktic foraminifera are rare in the basal portion of the section becoming common within the Second White Specks Formation with an assemblage consisting mostly of Heterohelix sp. and some Hedbergella sp..

\section{Stable isotope and TOC}

The $\delta^{13} \mathrm{C}$ and $\delta^{18} \mathrm{O}$ values through this section are fairly stable within the $720-744 \mathrm{~m}$ depth range in the core, but inconsistent above that interval. Variations in isotope and TOC values with depth are plotted and presented in Figure 8.

The $\delta^{13} \mathrm{C}$ values range between $-8.86 \%$ to $3.72 \%$, the $\delta^{13} \mathrm{C}_{\mathrm{org}}$ vary from $-27.77 \%$ to $24.33 \%$ and $\delta^{18} \mathrm{O}$ values range from $-13.93 \%$ to $-6.14 \%$. Stable isotope data are relatively stable at about $4 \%$ toward the bottom but fluctuate inconsistently above this interval. The $\delta^{13} \mathrm{C}_{\text {org }}$ values are fairly consistent from the base of the section, fluctuating 


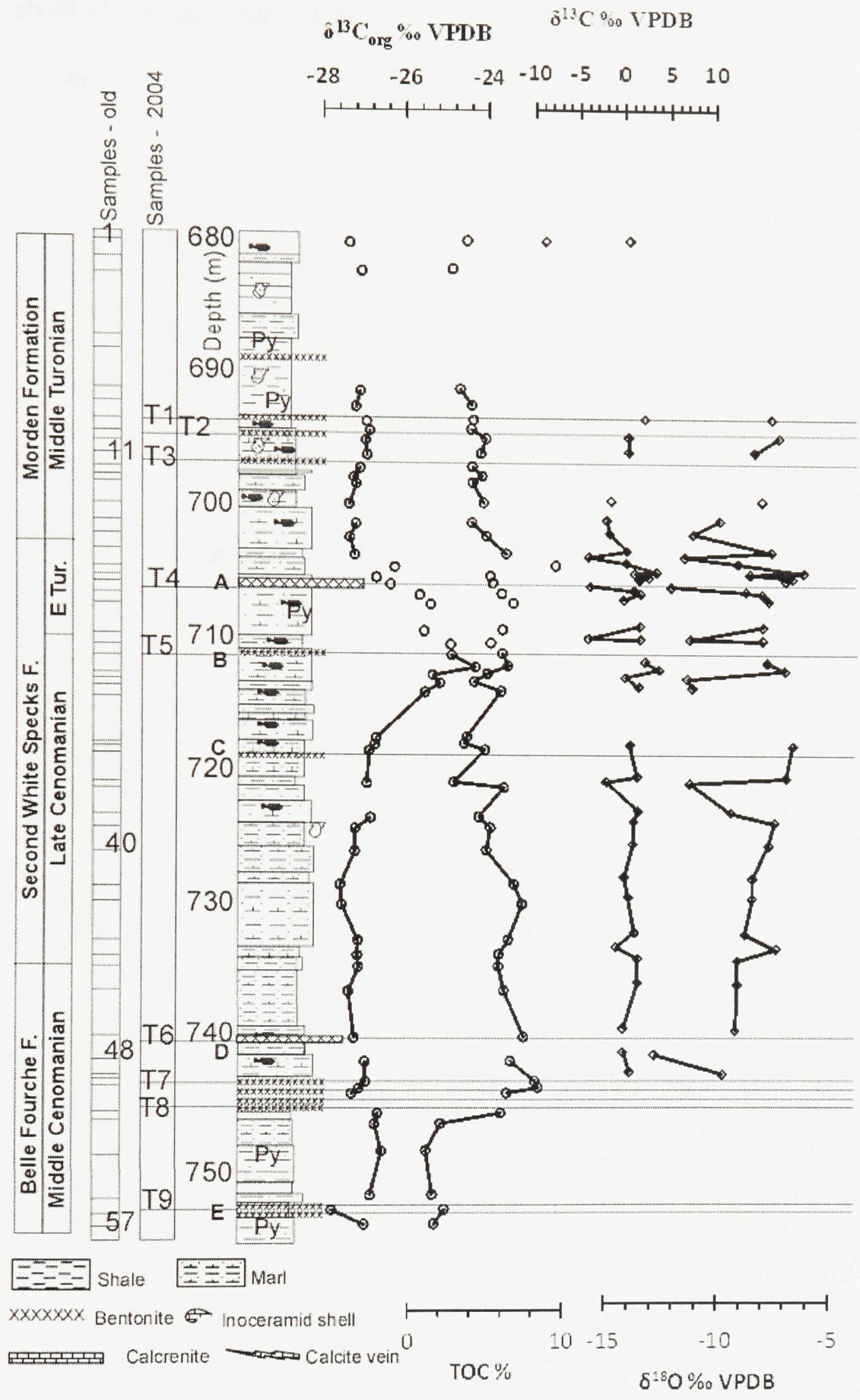

Figure 8: Measured section of the core from well 6-34-30-8w4 (Youngstown). Data are from Prokoph et al. (2000) and this study. The two bentonites (A and D) with high-resolution sampling across the bentonites are in yellow. 
about $-27 \%$, and then gradually increase to $\sim-24 \%$ at about $711 \mathrm{~m}$ depth, and gradually decrease from there to $-27 \%$ within the Early Turonian at about $705 \mathrm{~m}$ horizon.

The TOC values from the base of the section to about $745 \mathrm{~m}$ depth are $\sim 2 \%$, and then increase to about $9.5 \%$ at $745 \mathrm{~m}$ depth then gradual drops to $\sim 3.2 \%$ towards the $720 \mathrm{~m}$ interval towards the Early Turonian.

The $\delta^{13} \mathrm{C}$ and $\delta^{18} \mathrm{O}$ data shows no specific pattern, but $\delta^{13} \mathrm{C}_{\text {org }}$ and TOC values change from stable values recorded at the base of the section and shift positively upwards. The $\delta^{13} \mathrm{C}_{\text {org }}$ shift positively at about $718 \mathrm{~m}$ depth and declines back to the stable values at $705 \mathrm{~m}$ depth in the Early Turonian. TOC on the other hand shift positively at about $746 \mathrm{~m}$ depth and gradually declines to the values observed at the base towards the Early Turonian near the top of the core. The depths where the inflexions occur are thus different, unlike the case with VR1 and VR2 sections.

\section{Diagenetic and Vital Effects}

The dispersion diagrams of $\delta^{18} \mathrm{O}$ and $\delta^{13} \mathrm{C}$ (Figure 9) are characterized by a dispersed cluster rather than a strong linear correlation. The foraminifera specimen are not filled with cement (Figure 4), thus providing additional evidence that the analyzed planktic foraminifera had not undergone significant diagenesis and seem to have been unimpacted by vital effects and therefore can be used for paleotemperature estimations.

The isotopic composition of a carbonate shell will remain unchanged until the shell material dissolves and recrystallizes during diagenesis (Bickert, 2006). Diagenetic processes may be initiated during initial deposition and may originate from within the overlying water column due to the addition of corrosive deep ocean or pore waters 


$$
\frac{9}{8}
$$


enriched in $\mathrm{CO}_{2}$, derived from the respiration of organic matter mediated by specific bacteria. Wolf-Gladrow et al., 1999; Zeebe et al., 1999; Rink et al.,1998 all indicated that vital effects such as photosynthesis of the symbiotic algae, respiration of the hostsymbiont system, and calcification can drastically alter the $\mathrm{pH}$ of the seawater in the close vicinity (microenvironment) of the foraminifer.

Paleotemperature estimates can be derived from analysis of oxygen-isotope ratios obtained from foraminiferal tests, where increasing $\delta^{18} \mathrm{O}$ values correspond to decreasing temperatures, provided it has not been altered or impacted by diagenesis and vital effects.

\section{Trends across the bentonites}

The differences observed for $\delta^{13} \mathrm{C}_{\mathrm{carb}}, \delta^{18} \mathrm{O}, \delta^{13} \mathrm{C}_{\mathrm{org}}$ and TOC values from Heterohelix sp., Hedbergella sp., inoceramid prisms and bulk rock from below the bentonite to above the bentonite units, i.e. $0-3 \mathrm{~cm}$ from top of bentonites in the VR1 and V3 sections, and 0$10 \mathrm{~cm}$ from the top of the bentonite in the Youngstown section are used to evaluate whether these paleoenvironmental proxies fluctuate in response to volcanic eruptions.

\section{Vermilion River sections VR1 and VR2.}

Heterohelix sp.: The $\delta^{13} \mathrm{C}$ values shift negatively on the order of -0.36 to $-1.64 \%$ (see table 1) across the bentonites whereas $\delta^{18} \mathrm{O}$ values shift positively by $0.57-2.9 \%$. The isotopic trends and bentonite thicknesses characterizing the Vermilion River sections are shown in Table 1 and Figure 10.

Hedbergella sp.: The $\delta^{13} \mathrm{C}$ values shift negatively on the order of -1.33 to $-5.83 \%$ across the bentonites whereas $\delta^{18} \mathrm{O}$ values shift positively by $0.78-5.52 \%$ (Table 1 and Figure 10). 


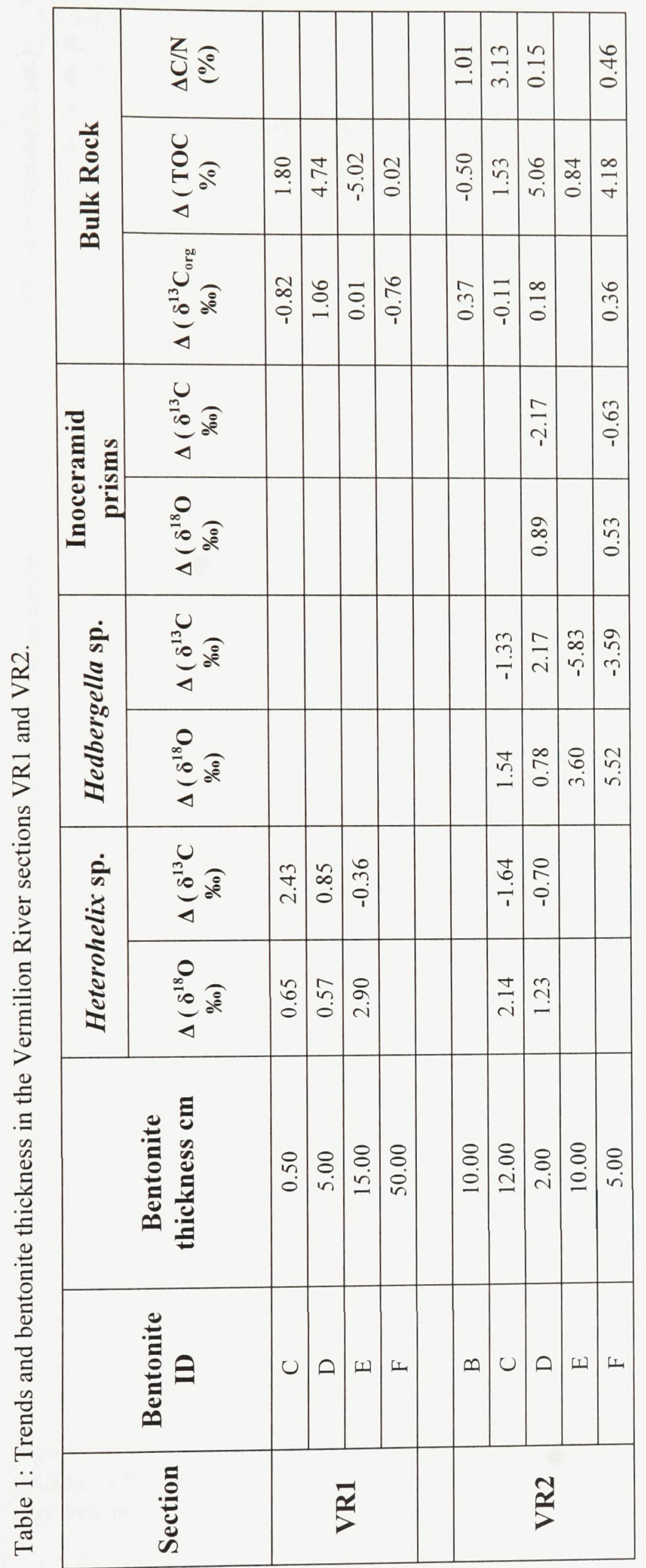



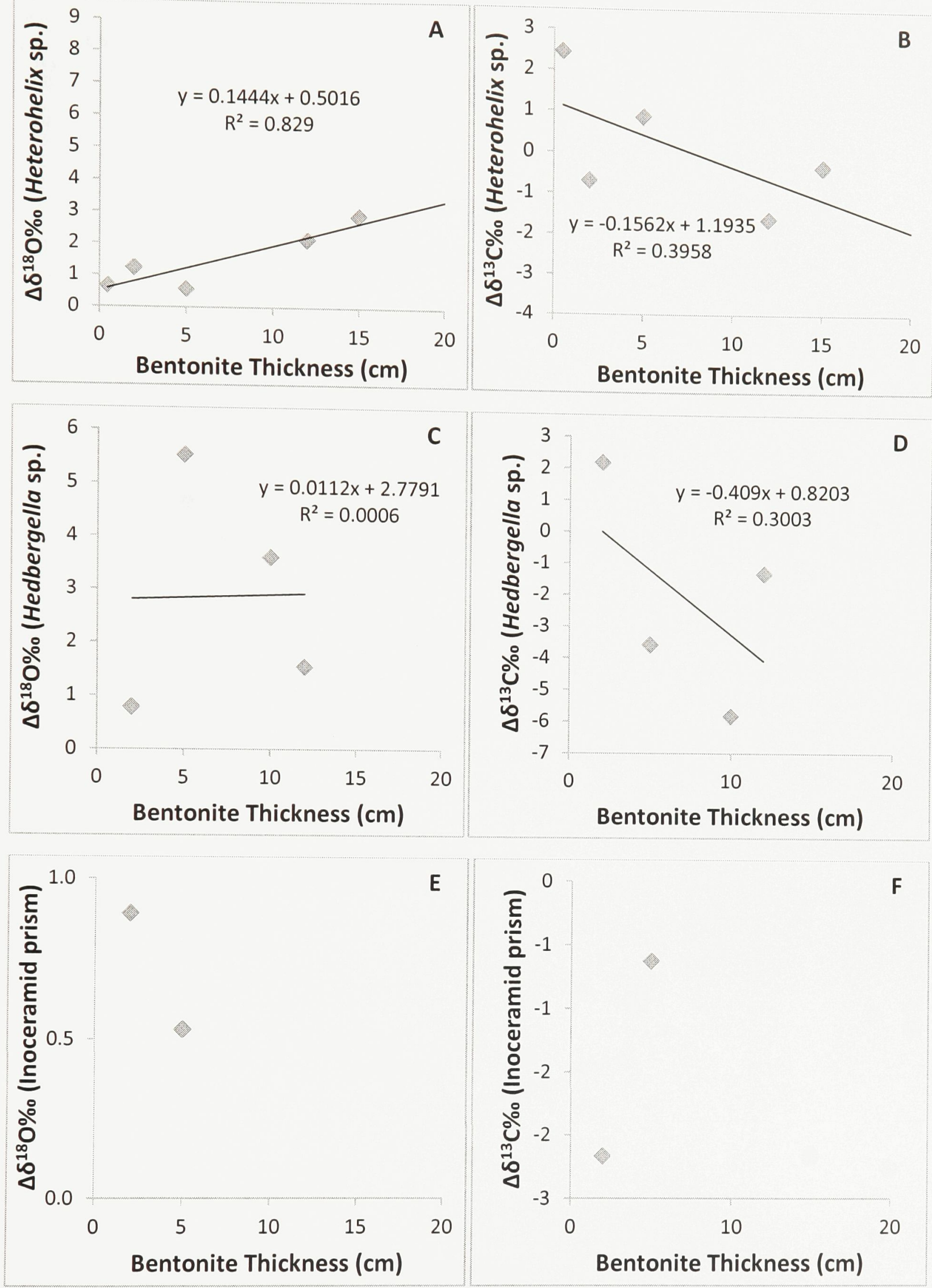

Figure 10: Changes in trend across bentonites vs. bentonite thicknesses in the Vermilion River sections VR1 and VR2. Note that bentonite-thickness trends are high in A, low in B and D, and very low in $\mathrm{C}$. 

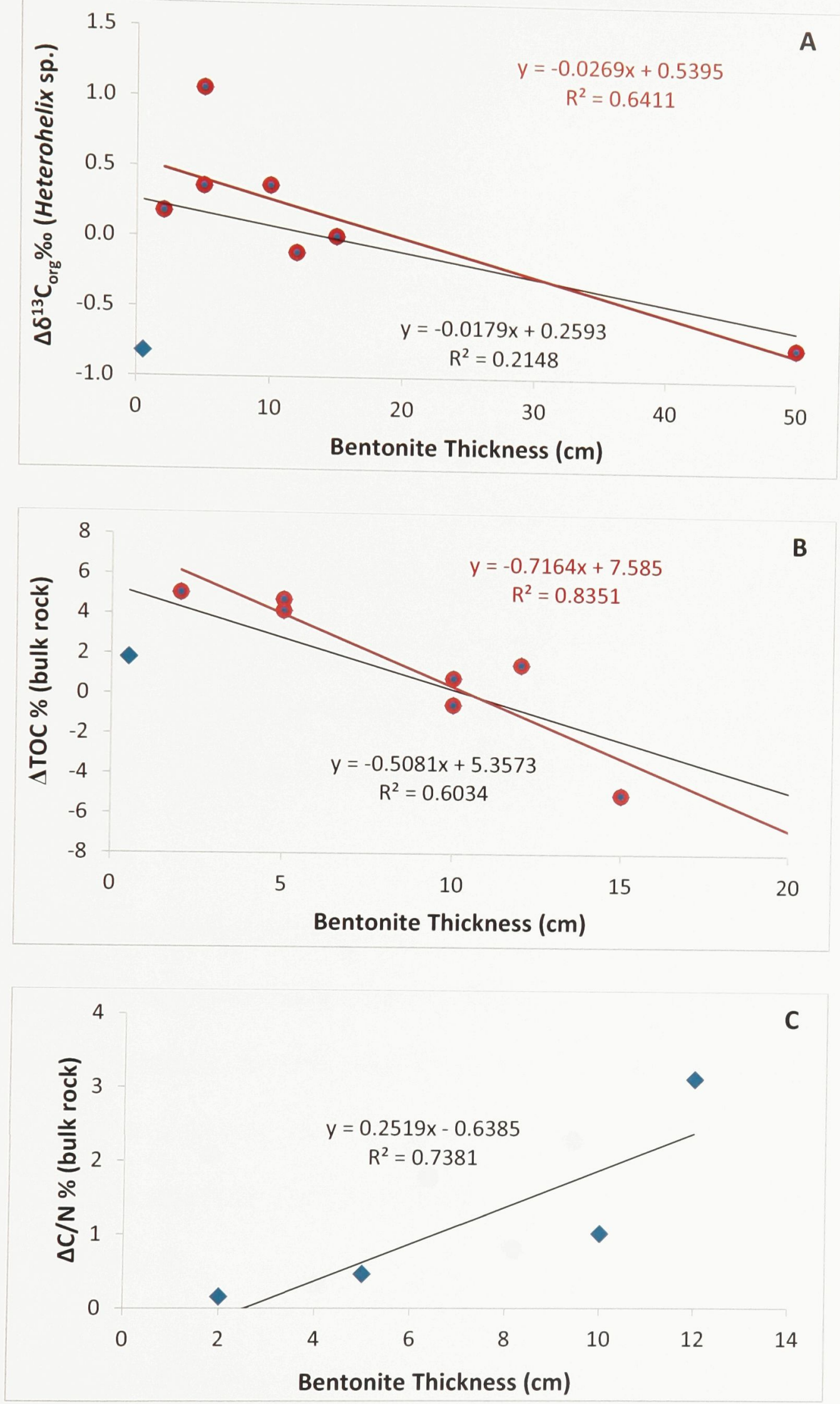

Figure 11: Change in trends vs. bentonite thicknesses in the Vermilion River sections VR1 and VR2. Note that $\Delta \mathrm{C} / \mathrm{N}, \Delta \mathrm{TOC}$ and $\Delta \delta^{13} \mathrm{C}_{\mathrm{org}}$ all shows high correlation with bentonite thickness especially with the exclusion of the very thin bentonite. 
Inoceramid prisms: The $\delta^{13} \mathrm{C}$ values shift negatively on the order of -0.63 to $-2.17 \%$ o across the bentonites whereas $\delta^{18} \mathrm{O}$ values shift positively by $0.53-0.89 \%$ (Table 1 and Figure 10).

Bulk rock: Both TOC and $\delta^{13} \mathrm{C}_{\mathrm{org}}$ also generally shift positively across the bentonite by $0.02-5.06 \%$ and $0.01-1.06 \%$ respectively.

\section{Correlation of trends with bentonite thickness}

The correlation of bentonite thickness with the isotope data is generally good, although the correlation coefficients are low for most units. The highest correlation coefficient $0.83,0.84$ and 0.74 are observed in $\Delta \delta^{18} \mathrm{O}$ for Heterohelix sp. (Figure 10A), $\Delta \mathrm{TOC}$ and $\Delta \mathrm{C} / \mathrm{N}$ (Figure 11B\&C) respectively, while as low as 0.00 and 0.30 correlation coefficients, are observed in Figure 10C\&D respectively. However, a consistent increase or decreases of geochemical proxies across the bentonites are readily discernible (Figure $5,6$ and 8$)$.

\section{Section 6-34-30-8w4 (Youngstown)}

There was insufficient data from this section to assess whether there was a correlation between bentonite thickness and the observed isotopic signatures in the 6-34-30-8w4 (Youngstown) section. The $\delta^{13} \mathrm{C}$ values for indicate an inconsistent shift varying from $0 \%$ - 5.4\%o across the various bentonites whereas $\delta^{18} \mathrm{O}$ values shift positively by $3.63-$ 5.1\%o (Table 2) 
Table 2: Trends and bentonite thickness in the Section 6-34-30-8w4 (Youngstown).

\begin{tabular}{|c|c|c|c|c|}
\hline \multirow{2}{*}{ Bentonites ID } & \multirow{2}{*}{ Depth $(\mathbf{m})$} & Bentonite Thickness $(\mathrm{cm})$ & \multicolumn{2}{|c|}{ Heterohelix sp. } \\
\cline { 4 - 5 } & & & $\Delta\left(\boldsymbol{\delta}^{\mathbf{1 8}} \mathbf{O} \% \mathbf{~}\right)$ & $\Delta\left(\boldsymbol{\delta}^{\mathbf{1 3}} \mathbf{C} \% \mathbf{0}\right)$ \\
\hline A & 705.60 & 3 & 5.1 & 5.4 \\
\hline D & 739.60 & 3 & 3.63 & 0 \\
\hline
\end{tabular}

\section{Magnitude of Events and Environmental Recovery}

The magnitude of volcanic event here can be generally assumed to be reflected by the thicknesses of the bentonites in the studied section $(0.5-50 \mathrm{~cm})$, and thus the expected effect on the environment should be related to the magnitude of these events.

Figure 12 - 15 shows the recovery trend across each of the focused bentonites in Vermilion River section VR2. The intercept on the interval axis (thickness above bentonites) indicates the sedimentation thickness above the bentonites coinciding with the full/total environmental recovery (i.e. back to pre-volcanic event condition). Assuming that the sedimentation rate in the Vermilion River was $1 \mathrm{~cm} / \mathrm{kyr}$ (Prokoph et al. 2000; Schröder-Adams et al. 1996 and McNeil and Caldwell, 1981), implies a recovery time of 8.2kyr for bentonite C, 12.3kyr for D, 17.6kyr for E and 16.1kyr for F.

\section{Synthesis/ Stratigraphic Correlation of Sections to Pueblo, USA}

A compilation of the stable-isotope, TOC, and elemental composition profiles as described above is shown in Figure 16. The stratigraphic sections studied for this research have been correlated with existing chemo- and biostratigraphic information from the Cenomanian-Turonian boundary section at Pueblo, Colorado, USA, which is the international recognized reference section for this boundary in the WIS (Keller and Pardo 

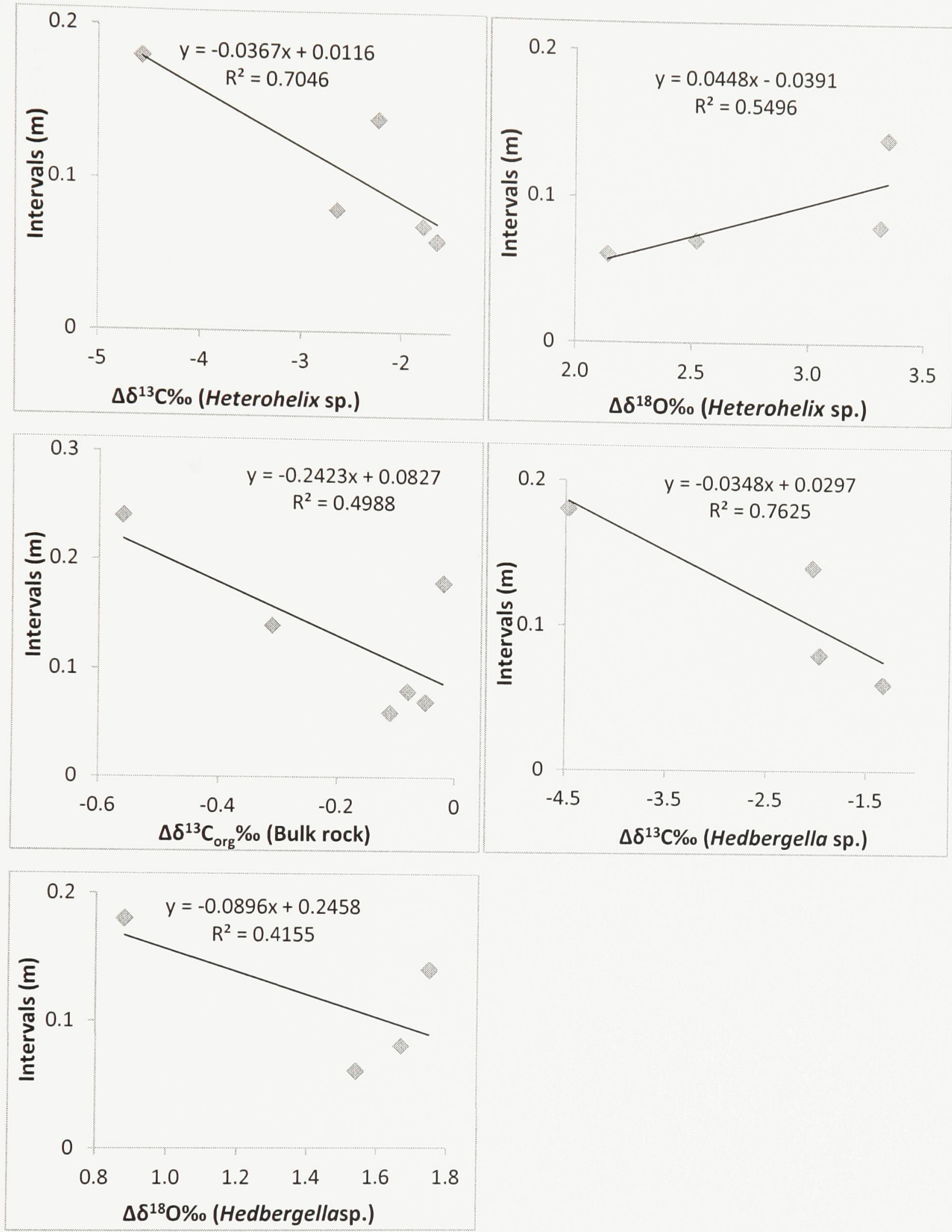

Figure 12: Environmental recovery for bentonite $\mathrm{C}$ from Vermilion River section VR2. The recovery is $\sim$ sedimentation thickness above bentonite $/$ Sedimentation rate $(0.08 \mathrm{~m} / \mathrm{cm} / \mathrm{kyr})=$ $0.08 * 100 \mathrm{kyr}=8 \mathrm{kyr}$. 

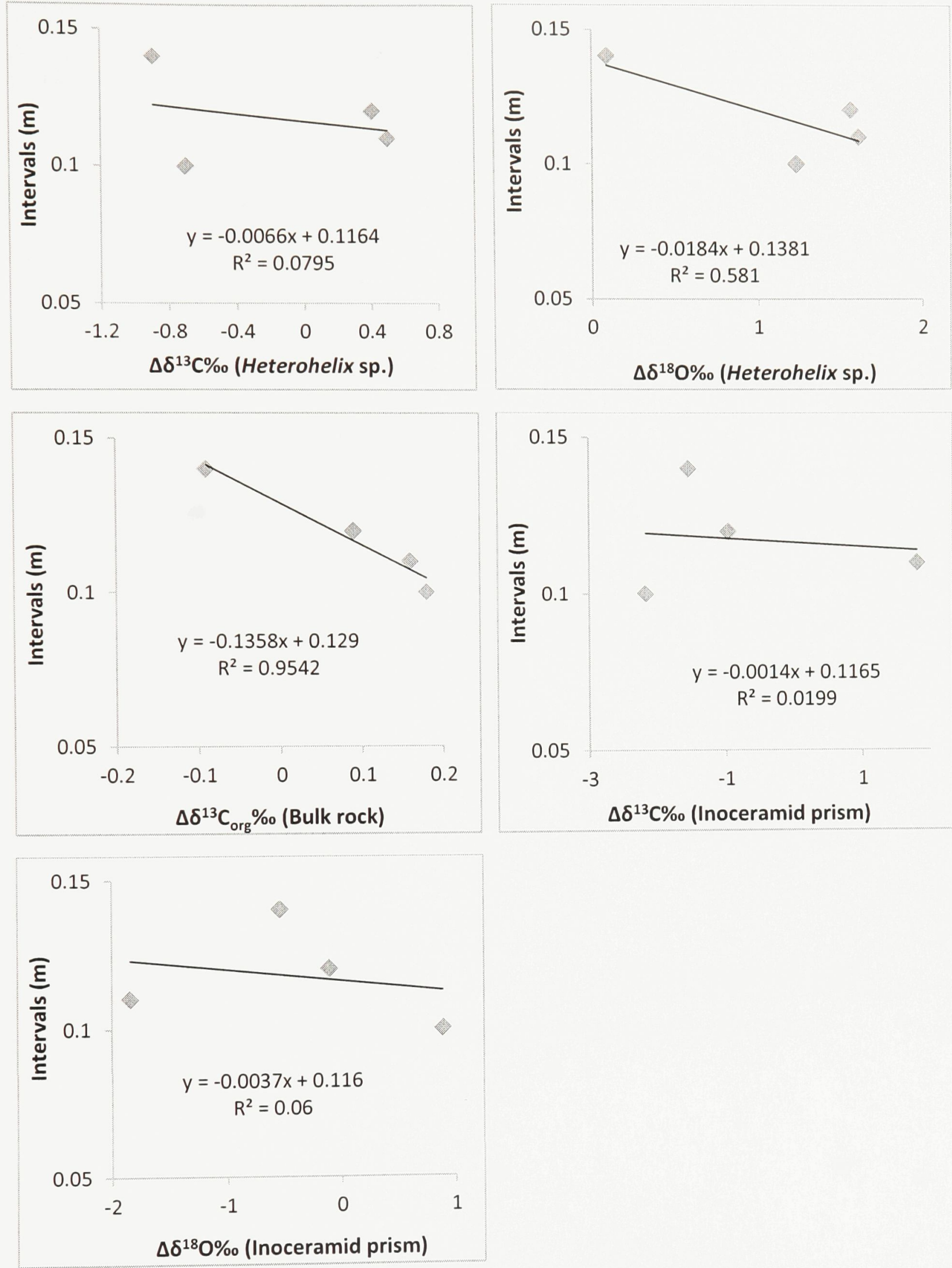

Figure 13: Recovery at bentonite D from Vermilion River section VR2. Recovery $\sim 0.12 \mathrm{~m} /$ $\mathrm{cm} / \mathrm{kyr}=12 \mathrm{kyr}$. 

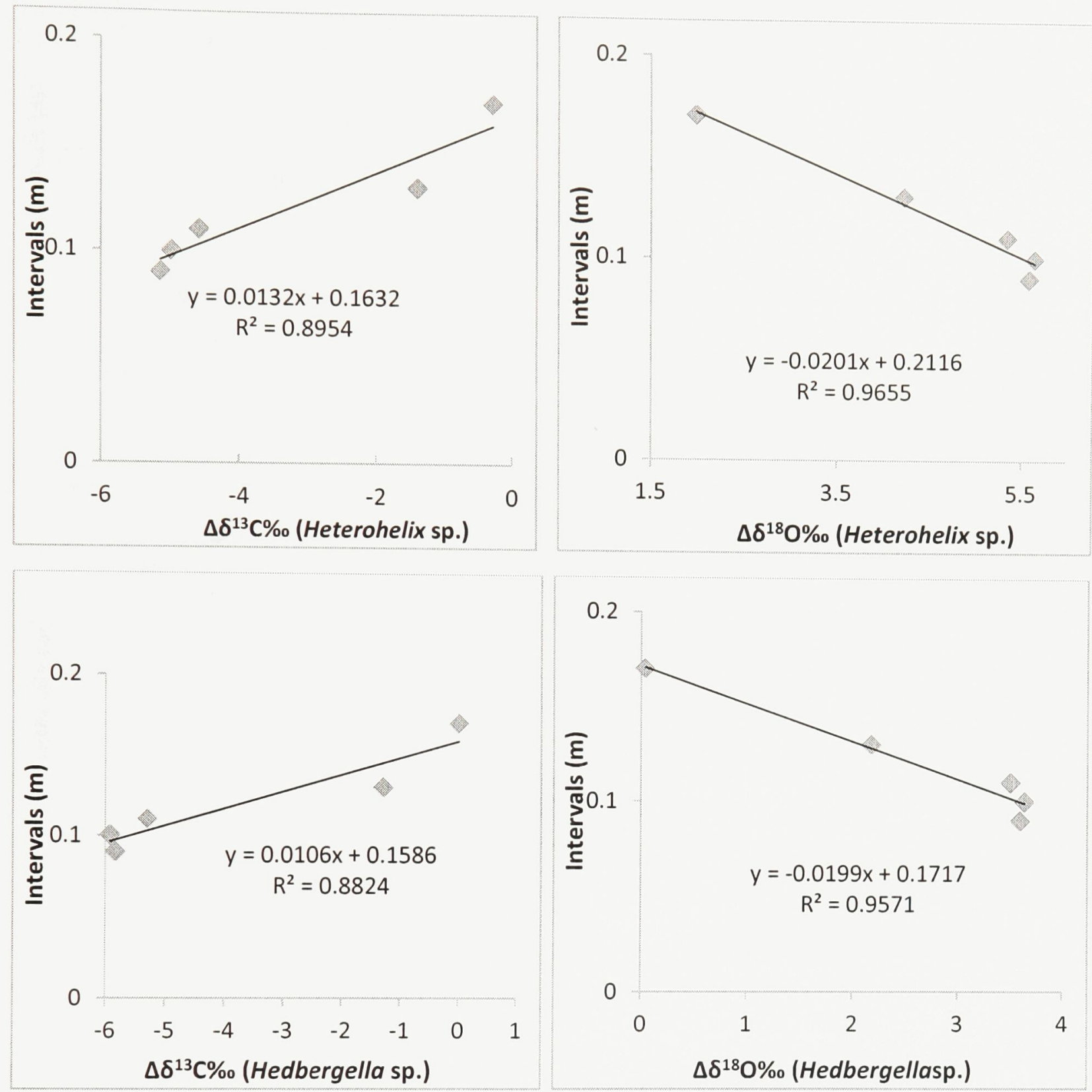

Figure 14: Recovery at bentonite E from Vermilion River section VR2. Recovery $0.18 \mathrm{~m} / \mathrm{cm} / \mathrm{kyr}=18 \mathrm{kyr}$. 

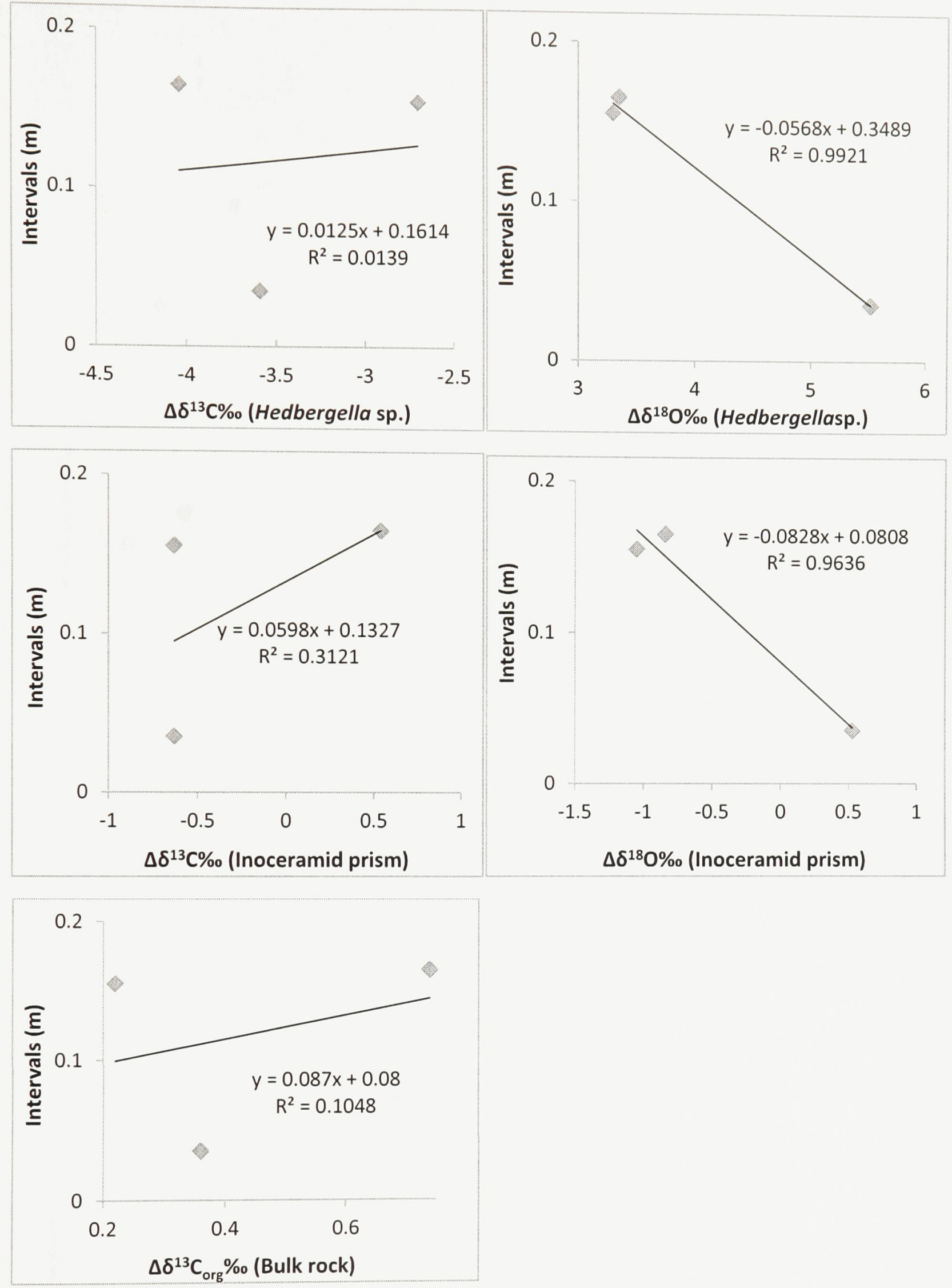

Figure 15: Recovery at bentonite F from Vermilion River section VR2. Recovery $\sim 0.16 \mathrm{~m} / \mathrm{cm} / \mathrm{kyr}$ $=16 \mathrm{kyr}$. 


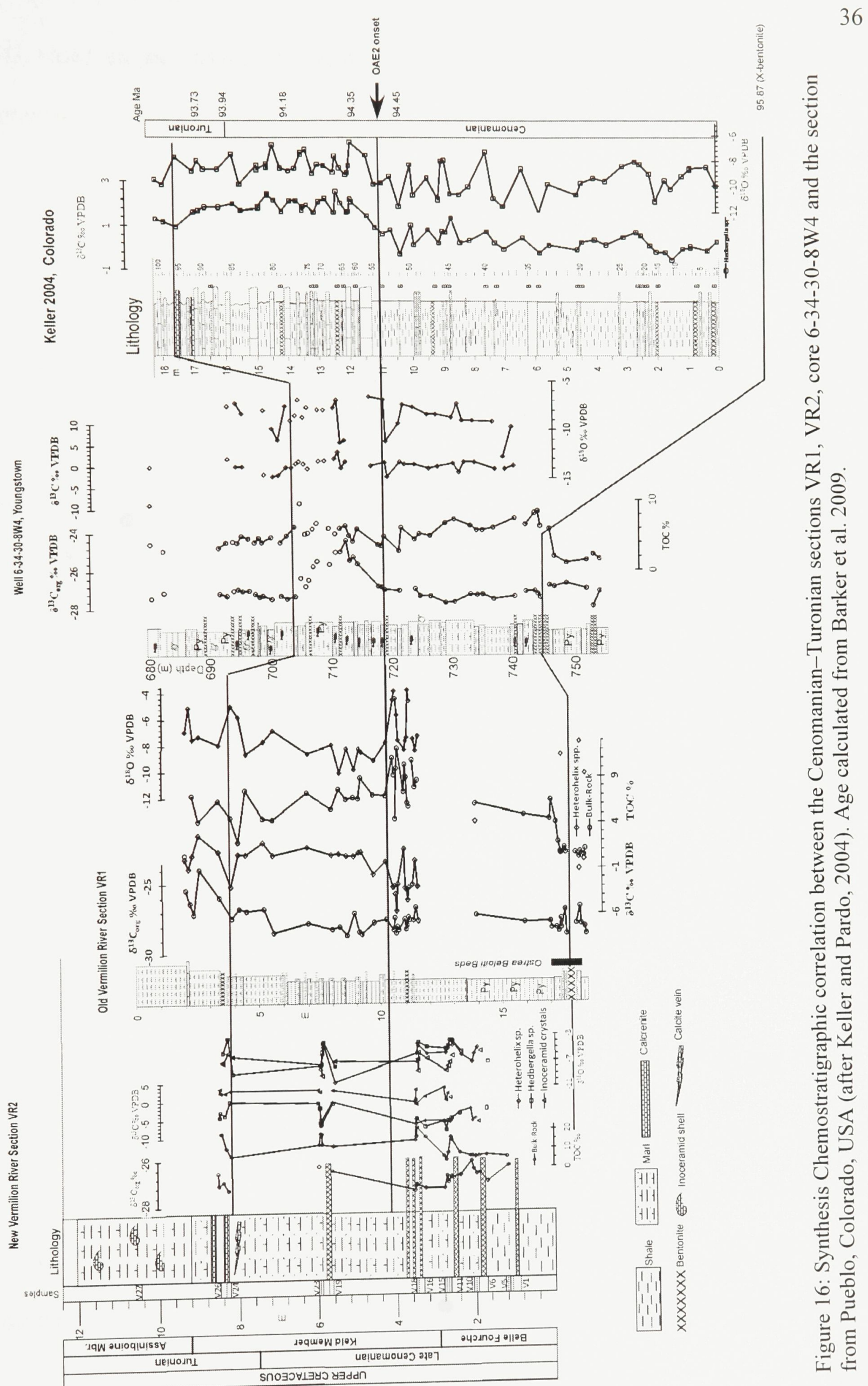


2004), based on the chronostratigraphic age as well as similar $\delta^{13} \mathrm{C}$ isotope excursion (Figure 16).

The chronostratigraphic age and $\delta^{13} \mathrm{C}$ isotope excursion across the $\mathrm{C}-\mathrm{T}$ boundary correlate closely between the two regions with the highest observed $\delta^{13} \mathrm{C}$ values all occurring within the same interval. The only observable difference is that the corresponding $\delta^{13} \mathrm{C}$ values from the Pueblo section are slightly heavier than the sections examined here.

\section{Paleotemperature interpretation}

During the 1940s, (Urey 1947) predicted that the ${ }^{18} \mathrm{O} /{ }^{16} \mathrm{O}$ ratio in calcite $\left(\mathrm{CaCO}_{3}\right)$ should vary as a function of the temperature at which the mineral precipitated.

Since this pioneering work the estimation of water temperature that prevailed during the precipitation of fossil calcite is now routinely estimated based on comparisons between the measuring $\delta^{18} \mathrm{O}$ value observed in calcite-secreting organisms (foraminifera, corals, and mollusks) and the $\delta^{18} \mathrm{O}$ values recorded in the water in which the organisms live. Based on this research various paleotemperature equations have been developed. For this study the equation below is utilized (Anderson and Arthur 1983);

$T=16-4.1 \times\left(\delta^{18} O_{\text {calcite }}-\delta^{18} O_{\text {water }}\right)+0.13 \times\left(\delta^{18} O_{\text {calcite }}-\delta^{18} O_{\text {water }}\right)^{2}$

where $\mathrm{T}$ and $\delta^{18} \mathrm{O}_{\text {water }}$ are the temperature $\left({ }^{\mathrm{O}} \mathrm{C}\right)$ and oxygen isotope value of the water in which the organism lived, and $\delta^{18} \mathrm{O}_{\text {calcite }}$ is the oxygen isotope value of the carbonate mineral measured. A clear difference in $\delta^{18} \mathrm{O}_{\text {water }}$ is observed when comparing results derived from Inoceramid prisms and planktic foraminifera (Table 3). The $\delta^{18} \mathrm{O}_{\text {water }}$ value 
for the Cretaceous period used in the literature range from 0 to $-4.7 \%$ (Faure, 1998; Anderson and Arthur, 1983; Fischer and Arthur, 2002) and this study use the different water mixing scenarios of Fisher and Arthur, 2002; Scenario $1, \delta^{18} \mathrm{O}_{\text {water }}=-4.7$ and $3.38 \%$ (Western and Boreal water mixed with Cretaceous seawater with resultant salinity of 31 and 33.3 ppt respectively) and scenario $2, \delta^{18} \mathrm{O}_{\text {water }}=-2.68$ and $-2.08 \%$ (Eastern water mixed with Cretaceous seawater with resultant salinity of 31 and $33.3 \mathrm{ppt}$ respectively).

\section{Type of Organic Matter}

A plot of organic matter compositions (Figure 17), C/N ratio vs. $\delta^{13} \mathrm{C}$ (top) as well as $\delta^{15} \mathrm{~N}$ vs. $\delta^{13} \mathrm{C}$ (bottom), indicate that the source of organic matter in the studied sections are primarily of $\mathrm{C}_{3}$ land plant origin. The Cretaceous vegetation of the Western Interior and adjacent regions of North America as recorded in its rocks, has been described by dominance of diverse gymnosperms and pteridophytes in the early Albian to Mid Cenomanian and dominance of flowering plants and conifers (Crane, 1987; Lidgard and Crane, 1988; Upchurch and Wolfe, 1993). A type III organic matter of terrestrial origin has also been recorded in the Belle Fourche and bottom $2 \mathrm{~m}$ of the Second White Speck Formations (Tu et al., 2007).

The distinctive $\delta^{13} \mathrm{C}$ values of $\mathrm{C}_{3}$ and $\mathrm{C}_{4}$ plants can be combined with the characteristic $\mathrm{C} / \mathrm{N}$ and $\delta^{15} \mathrm{~N}$ values of algal and land-plant tissues to identify the major sources of organic matter in sediments (Meyer, 1994; 2009 and Higginson, 2009), because different groups of organisms produce organic matter that contains different carbon and nitrogen 


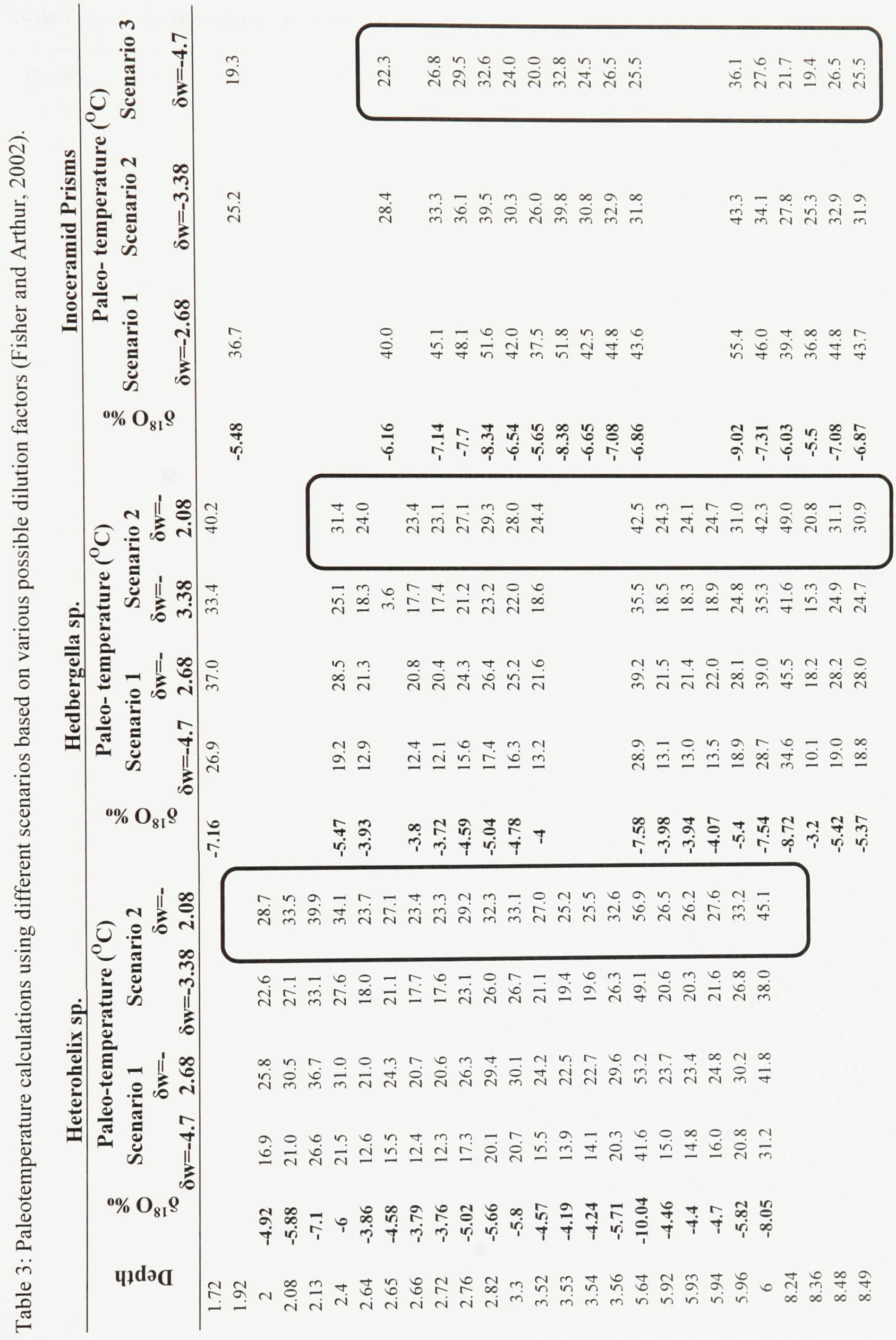


Table 4: Analysis for organic matter source.

\begin{tabular}{|c|c|c|c|c|c|}
\hline Depth & N \% & $\mathrm{C} \%$ & C/N Ratio & $\delta^{15} \mathrm{~N} \%$ & $\delta^{13} \mathrm{C}_{\text {org }} \%$ (VPDB) \\
\hline 1.2 & 0.2 & 5.69 & 28.39 & -1.06 & -26.34 \\
\hline 1.72 & 0.24 & 6.67 & 28.19 & -1.47 & -27.01 \\
\hline 1.92 & 0.21 & 6.17 & 29.2 & -1.2 & -26.64 \\
\hline 2 & 0.21 & 5.88 & 27.47 & -1.2 & -26.68 \\
\hline 2.08 & 0.23 & 6.28 & 27.63 & -1.12 & -26.47 \\
\hline 2.13 & 0.22 & 6.33 & 29.16 & -1.17 & -26.13 \\
\hline 2.4 & 0.3 & 7.86 & 25.95 & -1.48 & -26.73 \\
\hline 2.64 & 0.51 & 14.83 & 29.08 & -1.48 & -26.84 \\
\hline 2.65 & 0.56 & 16.17 & 28.9 & -1.64 & -26.78 \\
\hline 2.66 & 0.55 & 16.16 & 29.23 & -1.6 & -26.81 \\
\hline 2.72 & 0.29 & 7.94 & 27.06 & -1.35 & -27.04 \\
\hline 2.76 & 0.14 & 4.26 & 29.87 & -1.8 & -26.75 \\
\hline 2.82 & 0.22 & 6.3 & 28.52 & -1.98 & -27.29 \\
\hline 3.3 & 0.55 & 16.37 & 29.76 & -1.59 & -27.28 \\
\hline 3.52 & 0.72 & 21.42 & 29.91 & -1.75 & -27.1 \\
\hline 3.53 & 0.59 & 16.71 & 28.43 & -1.64 & -27.12 \\
\hline 3.54 & 0.75 & 22.14 & 29.54 & -1.6 & -27.19 \\
\hline 3.56 & 0.52 & 14.73 & 28.43 & -1.22 & -27.37 \\
\hline 5.64 & 0.43 & 11.94 & 27.67 & -2.38 & -26.49 \\
\hline 5.92 & 0.26 & 12.78 & 48.37 & -1.74 & \\
\hline 5.93 & 0.52 & 18.31 & 35.46 & -2.06 & \\
\hline 5.94 & 0.4 & 17.32 & 43.27 & -3.32 & \\
\hline 5.96 & 0.64 & 18.35 & 28.53 & -1.84 & -26.3 \\
\hline 6 & 0.43 & 12.8 & 29.98 & -1.63 & \\
\hline 8.24 & 0.27 & 7.09 & 26.4 & -1.99 & -27.3 \\
\hline 8.36 & 0.42 & 11.27 & 26.86 & -2.17 & -26.94 \\
\hline 8.48 & 0.67 & 18.76 & 27.95 & -1.91 & -27.08 \\
\hline 8.49 & 0.7 & 19.03 & 27.11 & -1.86 & -26.56 \\
\hline
\end{tabular}




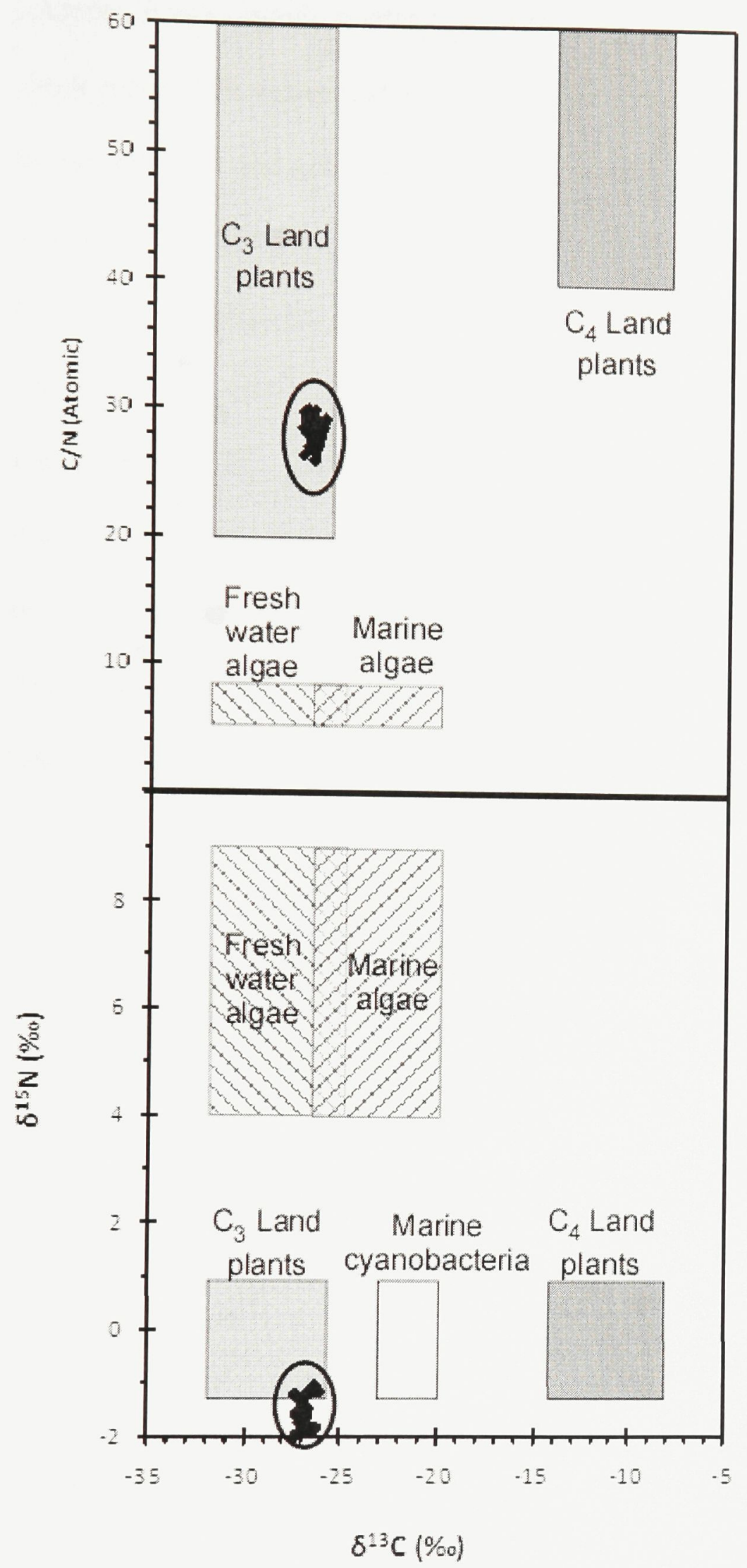

Figure 17: Generalized $\mathrm{C} / \mathrm{N}$ ratio vs. carbon isotopic (top) and nitrogen isotopic vs. carbon isotopic (bottom) compositions of organic matter, showing the data from this study plotting in the field of C3 land plants (after Meyers, 1994; 2009). 
contents. Fresh organic matter from aquatic algae is protein-rich and cellulose-poor and yields molar $\mathrm{C} / \mathrm{N}$ values that are commonly between 4 and 9 . Vascular land plants, which are protein-poor and cellulose-rich, create organic matter that usually has $\mathrm{C} / \mathrm{N}$ ratios of 20 and greater. Though, partial degradation of organic matter during early diagenesis sometimes modifies the generalized $\delta^{13} \mathrm{C}$ and $\mathrm{C} / \mathrm{N}$ values of organic matter in sediments (Müller, 1977), these ratios are sometimes sufficiently well preserved in shallow-marine sediments to allow a rough assessment of terrigenous organic matter contribution (e.g. Jasper and Gagosian 1990; Prahl et al. 1994). In most depositional settings, changes in the elemental composition of sedimentary organic matter are minor and do not erase the distinctive $\mathrm{C} / \mathrm{N}$ differences between the organic matter derived from aquatic algae and land plants (Meyers, 2009). 


\section{DISCUSSION}

The VR2 section was sampled at high resolution across the bentonites, with significant volcanism-induced negative and positive excursions in $\delta^{13} \mathrm{C}$ and $\delta^{18} \mathrm{O}$ isotopic values. Attempts to relate analytical trends across the bentonites to the thickness yielded a generally good (4 high, 2 low and 1 very low) correlations from the VR2 section. The lack of strong correlations in some are due to limited data and thinness of some bentonites. Other possible reasons could be due to the source distance of each bentonite, the direction of transport of the ejected materials and the amount of ejected material and associated gas.

The apparent synchronicity between volcanism and an episode of climate cooling suggests that there could be a causal link between explosive volcanic activity and regional cooling. However, due to the short-lived nature of volcano-induced stratospheric clouds, the long-term effects on global climate have been considered rather ephemeral (Lee et al. 2004). The samples for this study were collected to encompass the 30,000 years after each bentonite deposition in order to capture the short-lived volcanic effects.

In the sections studied, as well as observed elsewhere throughout most of the WCSB, most C-T strata are either barren or contain only sparse low diversity assemblages of planktic foraminifera. For example, the Belle Fourche Formation is barren of planktic foraminifera in the basin center (Tu et al. 2007) while the Keld Member and Second White Specks Formation are characterized by a low diversity planktic foraminiferal fauna. Based on the observed distribution of benthic foraminifera and other fossil groups, 
Schröder-Adams et al. (2001) have suggested that dysoxic to anoxic bottom water conditions persisted for most of Cenomanian/Turonian in the WCSB.

The $\delta^{13} \mathrm{C}$ values above the barren zone (mid Cenomanian) are slightly lighter, but become heavier by the Late Cenomanian and then reverse to being lighter towards the early Turonian. The observed $\sim 4.5 \%$ positive shift in $\delta^{13} \mathrm{C}$ in all sections, which correlates with a similar enrichment recorded in the Pueblo, Colorado section (Keller and Pardo, 2004) provides further confirmation of the widespread character of the positive carbon isotope excursions during $\mathrm{OAE} 2$. In contrast to the $\delta^{13} \mathrm{C}$ record, the observed $\delta^{18} \mathrm{O}$ values above the mid-Cenomanian barren zone are slightly heavier becoming lighter by the Late Cenomanian becoming reversed to being heavier by the early Turonian.

Analysis of $\delta^{13} \mathrm{C}$ and $\delta^{18} \mathrm{O}$ from foraminifera and inoceramid prisms in the VR2 Section reveals remarkably similar trend, though inoceramid has enrichment of $\sim 3-4 \%$ in $\delta^{13} \mathrm{C}$ and depletion of up to $2 \%$ in $\delta^{18} \mathrm{O}$. Inoceramid prisms are known to produce such enriched $\delta^{13} \mathrm{C}$ and depleted $\delta^{18} \mathrm{O}$ relative to other carbonate species (He et al., 2005; Fisher and Arthur, 2002; Kyser et al., 1993). The difference in the stable isotope compositions of the planktic foraminifera and inoceramid would imply that inoceramid, believed to be part of the benthic epifauna (e.g., Kaufman, 1984), inhabits the upper part of the water column in the seaways, well above the benthic foraminifera. Several possibilities as to why the inoceramids diverge from a benthic signal has been discussed (e.g. Fisher and Arthur, 2002.), yet there is no satisfactory explanation for their stable isotopic relationships. 
TOC as well as $\delta^{13} \mathrm{C}_{\text {org }}$ within the mid Cenomanian Belle Fourche Formation are generally low with TOC of $\sim 2 \%$ and $\delta^{13} \mathrm{C}_{\text {org }}$ of $\sim-28 \%$ except for within the VR2 section where TOC is as much as $6 \%$. However, in the late Cenomanian Keld member/Second White Specks Formation, the TOC shifts positively to $>11 \%$ with the VR2 section recording up to $15 \%$, while $\delta^{13} \mathrm{C}_{\text {org }}$ only significantly shift positively at the LateCenomanian/Early Turonian boundary, rapidly followed by a negative excursion in the early Turonian.

Tu et al. (2007) reported TOC values for the Belle Fourche Formation ranging from $1.46 \%$ to $4.49 \%$, with an average of $2.56 \%$. Leckie et al., (1994) characterized Second White Specks Formation as having high TOC values; Tu et al. (2007) reported an average of $8.20 \%$ with a range from $3.75 \%$ to $11.04 \%$. However, none of these studies emphasized changes across bentonites.

There is a coincidental increase in TOC with the positive $\delta^{13} \mathrm{C}$ excursion during the late Cenomanian, suggesting that increased carbon burial may have been responsible for generating the isotope excursion as suggested from previous studies (Jenkyns, 1980; Jenkyns, 1985; Schlanger et al., 1987; Wan et al., 2003; and Loydell and Fryda, 2007). This carbon burial may have been enhanced by a higher sedimentation rate during burial.

\section{Diagenetic and Vital Effects}

Ambient water temperature and the $\delta^{18} \mathrm{O}$ values derived from seawater $(\delta \mathrm{w})$ determines the $\delta^{18} \mathrm{O}$ value ultimately taken up by foraminifera and deposited in their tests, while observed $\delta^{13} \mathrm{C}$ values are primarily a function of the level of dissolved inorganic carbon (DIC) $\delta^{13} \mathrm{C}$ values in seawater (e.g., Urey, 1947; Epstein et al. 1953; Emiliani, 1955; 
O’Neil et al. 1969; Graham et al. 1981; McCorkle et al. 1990). However, this straight forward relationship is often complicated by biological vital effect, as well as postdepositional diagenesis and recrystallization of fossil carbonate.

Few extreme low $\delta^{18} \mathrm{O}$ values in the data are outliers which are probably influenced by diagenesis, or may be a product of more acidic ocean waters and lower $\mathrm{pH}$ following in an environment characterized by frequent volcanic eruptions. Another possible cause may be due to mixing of low $\delta^{18} \mathrm{O}$ fresh water.

The cross plot of $\delta^{18} \mathrm{O}$ and $\delta^{13} \mathrm{C}$ derived from the data set however indicated that the analyzed Heterohelix, Hedbergella and inoceramid shells had not undergone significant diagenesis and seem to have been unimpacted by vital effects. It has previously been reported that inoceramids prism are particularly resistant to diagenetic influences (Kyser et al., 1993).

He et al., (2005) suggested that variable paleoenvironmental conditions rather than vital effects likely account for the heterogeneity in stable-isotope compositions of inoceramids. Thus, the $\delta^{18} \mathrm{O}$ lightening is the probable response to isotopic fractionation produced by a temperature increase and consequently, absolute temperature interpretations from our data are meaningful.

The difference in $\delta^{18} \mathrm{O}$ values suggests that Hedbergella live in a position in the water column below the associated Heterohelix (Fisher and Arthur, 2002.) rather than vital effect. The slight $\delta^{13} \mathrm{C}$ enrichment in Heterohelix compared to Hedbergella also further buttress the fact that Heterohelix is the shallowest dwelling planktic foraminifer of the 
two. Leckie, 1987 and Leckie et al., 1998 have suggested that Heterohelix was a eurytropic, opportunistic genus that lived in the near-surface waters.

The $\delta^{18} \mathrm{O}$ isotope composition of inoceramid shells has been assumed to be equivalent to that of benthic foraminifers in some studies (Hudson and Anderson, 1989; Schönfeld et al., 1991; MacLeod and Hoppe, 1992); accordingly, calcium carbonate from shells was precipitated in equilibrium with near-seafloor water.

\section{Paleoenvironmental Implications}

Stable isotopes of carbon and oxygen are very useful proxies for paleoclimate reconstruction (Sageman and Hollander, 1999; Alley and Cuffey, 2001). For estimates of paleotemperature this study utilized the various water mixing scenarios proposed by Fisher and Arthur (2002) for the Cretaceous. They have suggested surface to bottom water values in the WIS ranging from $-1.00 \%$ to $-4.47 \%$ (SMOW) with paleosalinities ranging from 31.0 to $33.3 \mathrm{ppt}$.

Assuming a $\delta^{18} \mathrm{O}$ value of $-1 \%$ for the water in the seaway, the temperatures conversion of $\delta^{18} \mathrm{O}$ values for the inoceramids would be in the excess of $48^{\circ} \mathrm{C}$, whereas the $\delta^{18} \mathrm{O}$ values of the foraminifera would indicate more reasonable temperatures of $35^{\circ} \mathrm{C}$. These temperature differences between the surface and bottom waters are the reverse of the expected normal distribution of temperatures in the seaway (He et al., 2005). Even if inverse temperature stratification existed, it would not have likely persisted through much of the Late Cretaceous (He et al., 2005).

Surface and water bottom temperatures were calculated using the $\delta^{18} \mathrm{O}$ of planktic foraminifera and inoceramid prisms respectively with different scenarios (see Table 3). 
Scenario $2 \mathrm{~b}$ for the surface temperature (planktic foraminifera) and scenario 3 for the bottom temperature (inoceramid) seems more reasonable since it allows for a normal thermocline. Also, Bijma et al., 1990 have shown from laboratory studies that few planktic foraminifera can survive and reproduce in temperatures up to $32^{\circ} \mathrm{C}$ and tolerate 24-47 ppt salinity.

There is a general warming trend from the mid-Cenomanian to early Turonian, which is in line with presumed continual continental warming from the Albian to Turonian (Frakes, 1999). However, there were occasional regional cooling periods that might be related to short-term Mid-Cretaceous cooling trends (e.g. Bornemann et al., 2008).

After removing the excursions due to volcanism from the VR2 section data the most pronounced warming trend is an $\sim 1.5 \%$ o decrease in $\delta^{18} \mathrm{O}\left(\sim 6.5^{\circ} \mathrm{C}\right)$, which occurred early in the Late Cenomanian. Conversely, there are estimated cooling trends in the range of $0.57-5.52 \%$ o $\left(\sim 7-22^{\circ} \mathrm{C}\right)$ across the bentonites, in part reflecting the effect of volcanic events. Extreme temperature drop $>10^{\circ} \mathrm{C}$, though may happen regionally over few years, probably never occurred in Earth history over a thousand of years. It is more probable that this single extreme shift is due to a combination of diagenesis, salinity or vital effects in the particular epicontentinental basin setting of the WSCB. Stoll and Schrag (2000) recorded $4^{\circ}-8^{\circ}$ of cooling from Italy and Spain. It is thus likely that any observed $\delta^{18} \mathrm{O}$ values $>\sim 2 \%$ are highly influenced by diagenesis, or may be a product of more acidic ocean waters and lower $\mathrm{pH}$ following in an environment characterized by frequent volcanic eruptions. 


\section{Magnitude of Events and Environmental Recovery}

Though the thicknesses of bentonites can reflect the magnitude of the eruptions, however, the transportation of ash by wind has been considered primarily responsible for bentonite bed thickness and areal extent (Slaughter and Earley, 1965). Studies of Cretaceous bentonites in the Black Hills and Hardin districts of Montana, Wyoming, and South Dakota by Knechtel and Patterson $(1956,1962)$ indicated that many of those bentonites change radically in thickness over distances of several kilometers or less.

Though there were evidences for variation in bentonite thicknesses across the basin, the X-bentonite has always been found at thicknesses $>0.4 \mathrm{~m}$ and nether been completely eroded in the WCSB as evident from cores, outcrops and gamma-ray logs (Bloch et al. 1993, Prokoph et al. 2000). The strong correlation between changes across bentonites and bentonite thickness is strongly indicative of relationship between bentonite thickness and magnitude of volcanic event. However, our results emphasize the need for further examination of the relationship.

As might be expected the ecological recovery time following eruptions varies as each event may be different in source and location or may be specific in the amount of ejected gas and solid particles. 


\section{CONCLUSIONS}

The high-resolution stable isotope data acquired in the Vermilion River section, especially the VR2 section has provided valuable isotopic data derived from sedimentological and paleontological material to provide an indication of the paleoenvironmental impact of Mesozoic volcanic eruptions within the Western Interior Seaways WCSB. The impact of these repeated volcanic episodes on C-T climate within the region was very rapid and can only be temporally resolved using the high-resolution sampling strategy employed in this study.

Dispersal cross plots of $\delta^{18} \mathrm{O}$ and $\delta^{13} \mathrm{C}$ indicated that in most samples the Heterohelix, Hedbergella and inoceramid shells did not undergo significant diagenesis or are affected by any vital effects. Rather, the calcium carbonate from their shells was precipitated in isotopic equilibrium with deep-sea water, hence very useful for paleoenvironmental proxies.

Significant isotopic shifts are comparable to previously published trends in wellpreserved forams and inoceramid calcite isotopic ratios from this region and globally. The background trends in $\delta^{18} \mathrm{O}, \delta^{13} \mathrm{C}$, and TOC from mid Cenomanian to Early Turonian are quite similar to other data in the WIS/WCSB. The data generally reflect two major trends/events; the mid Cenomanian cool period and the warm late Cenomanian/early Turonian period which incorporate the OAE2.

TOC as well as $\delta^{13} \mathrm{C}_{\mathrm{org}}$ indicate low organic content in the mid Cenomanian Belle Fourche Formation but became very high in the late Cenomanian Keld member/Second White Specks Formation, but again become low by early Turonian. Increased TOC 
coincident with the positive $\delta^{13} \mathrm{C}$ excursion suggests that increased carbon burial may have been responsible for generating the isotope excursion.

High-resolution $\delta^{13} \mathrm{C}$ and/or $\delta^{13}$ Corg trends from the three sections from WCSB allows for the correlation within the region, especially with the C-T OAE2 boundary reference section at Pueblo, Colorado. The $\delta^{13} \mathrm{C}$ record from the Pueblo section, Colorado shows the widely recorded late Cenomanian positive $\delta^{13} \mathrm{C}$ excursion which correlate precisely with sections in this study.

The excursions of $\delta^{13} \mathrm{C}, \delta^{18} \mathrm{O}$ and $\delta^{13} \mathrm{C}_{\text {org }}$ above the barren zone (mid Cenomanian) define the onset of the OAE2 confirming previous works especially from the global character of the positive carbon isotope excursions.

The magnitude of the eruptions is reflected in the bentonites thicknesses which range from $0.5-50 \mathrm{~cm}$ within the studied section. The timing of environmental recovery at each of the bentonites are; $8.2 \mathrm{ky}$ at bentonite $\mathrm{C}, 12.3 \mathrm{kyr}$ at $\mathrm{D}, 17.6 \mathrm{kyr}$ at $\mathrm{E}$ and $16.1 \mathrm{kyr}$ at $\mathrm{F}$. Hence the general timing for the recovery from the volcanic events on the environment always take $<20 \mathrm{kyr}$. The range of $\delta^{18} \mathrm{O}$ changes across bentonites with thickness $5-12 \mathrm{~cm}$ is $0.57-2.14 \%$ which translate to $\sim 2.28-8.56^{\circ} \mathrm{C}$ cooling. 


\section{REFERENCES}

Alley, R.B., and Cuffey, K.M., 2001. Oxygen- and Hydrogen-isotope ratios of water in precipitation: beyond paleothermometry. In Valley, J.W., and Cole, D., (Eds.), Stable Isotope Geochemistry, Reviews in Mineralogy and Geochemistry Vol. 43, Mineralogical Society of America, Washington, DC, Chapter 9, 527-553.

Amajor, L.C., 1985. Biotite grain size distribution and source area of the Lower Cretaceous Viking bentonites, Alberta, Canada. Bulletin of Canadian Petroleum Geology, 33: 471-478.

Anderson, T.F., and Arthur, M.A., 1983. Stable isotopes of oxygen and carbon and their application to sedimentologic and paleoenvironmental problems. In Arthur, M.A., Anderson, T.F., Kaplan, I.R., Veizer, J., and Land, L.S. (Eds.), Stable Isotopes in Sedimentary Geology, Society of Economic Paleontologists and Mineralogists Short Course, 10: 1-151.

Arthur, M.A., Jenkyns, H., Brumsack, H., and Schlanger, S., 1988. Stratigraphy, Geochemistry, and Paleoceanography of organic-carbon-rich mid-Cretaceous sequences. In: Beaudoin, B., and Ginsburg, R., (Eds.), Cretaceous Resources, Events, and Rhythms, Digne, France, : 25-70.

Barker, I.R., Moser, D.E., Plint, A.G., Kamo, S L., 2009. High-Precision ID-TIMS U-Pb Zircon Geochronology of Two Transcontinental Cenomanian Bentonites From the Western Canada Foreland Basin. Proceedings of the 2009 American Geophysical Union Joint Assemby. [np].

Barron, E.J., 1983. A warm, equable Cretaceous: The Nature of the problem. Earth Sci. Rev., 19: 305-338.

Benton, M.J., and Twitchett, R.J., 2003. How to kill (almost) all life: The end-Permian extinction event: Trends in Ecology and Evolution, 18: 358-365.

Berner, R.A., 2002. Examination of hypothesis for the Permo-Triassic boundary extinction by carbon cycle modeling, Proceedings of the National Academy of Sciences United States of America 99: 4172-4177.

Bickert, T., 2006. Influence of geochemical processes on stable isotope distribution in marine sediments. In Schulz, H. D., and Zabel, M., (Eds.), Marine Geochemistry (2nd ed.). Springer Verlag, Berlin, : 339-369.

Bijma, J., Faber, W.W., Jr., and Hemleben, C., 1990. Temperature and salinity limits for growth and survival of some planktonic foraminifers in laboratory cultures. $J$. Foraminifer. Res. 20: 95-116.

Bloch, J.D., Schröder-Adams, C.J., Leckie, D.A., McIntyre, D.J., Craig, J., and Staniland, M., 1993. Revised stratigraphy of the lower Colorado Group (Albian to Turonian), western Canada. Bulletin of Canadian Petroleum Geology 41: 325-348.

Bloch, J.D., Schröder-Adams, C.J., Leckie, D.A., Craig, J., and McIntyre, D.J., 1999, Sedimentology, micropaleontology, geochemistry, and hydrocarbon potential of shale from the Cretaceous Lower Colorado Group in western Canada. Geological Survey of Canada, Bulletin 531: 185.

Bornemann, A., Norris, R.D., Friedrich, O., Beckmann, B., Schouten, S., Damsté, J.S.S., Vogel, J., Hofmann, P., and Wagner, T., 2008. Isotopic evidence for glaciation during the Cretaceous supergreenhouse. Science, 319: 189-192. 
Caldwell, W.G.E., 1984. Early Cretaceous transgressions and regressions in the southern Interior Plains. In Stott, D.F., and Glass, D.J., (Eds.), The Mesozoic of Middle North America. Canadian Society of Petroleum Geologists Memoir, 9: 173-203.

Caldwell, W.G.E., North, B.R., Stelck, C.R., and Wall, J.H., 1978. A foraminiferal zonal scheme for the Cretaceous System in the Interior Plains of Canada. In Stelck, C.R., and Chatterton, B.D.E., (Eds.), Western and Arctic Canadian Biostratigraphy. Geological Association of Canada Special Paper, 18: 495-575.

Chappell, J., and Shackleton, N.J., 1986. Oxygen isotopes and sea level. Nature, 324: $137-140$.

Collins, D.S., 1987. A preliminary report on the bentonite beds of the lower Virgin Creek Member of the Pierre Shale, Stanley County, South Dakota. Mountain Geologist, 24:
$81-85$.

Coplen, T.B., and Schlanger, S.O., 1974. Oxygen and carbon isotope studies of carbonate sediments from Site 167, Magellan Rise, Leg 17. In Winterer, EX., Ewing, J. I., et al., (Eds.) Initial Reports of the Deep Sea Drilling Project, Washington (U.S. Government Printing Office) 17: 505.

Desmares, D., Beaudoin, B., Grosheny, D., Gauthier-Lafaye, F., and Stille, P., 2002. High-resolution variability of stratigraphic records constrained by volcanic ashes at the Cenomanian-Turonian Boundary in the Western Interior Basin. GSA Annual meeting, Denver, October 27-30, 2002, abstract 61-9.

Douglas, R.G., and Savin, S.M., 1975. Oxygen and carbon isotope analyses of Tertiary and Cretaceous microfossils from the Shatsky Rise and other sites in the North Pacific Ocean. In Larson, R.L., and Moberly, R., et al., (Eds.), Initial Reports of the Deep Sea Drilling Project 32, U.S. Govt. Printing Office, Washington, D.C., : 509520.

Elder, W.P., 1988. Geometry of Upper Cretaceous bentonite beds; Implications about volcanic source areas and paleowind patterns, Western Interior, United States. Geology, 61: 835-838.

Emiliani, C., 1955. Pleistocene temperatures, Journal of Geology, 63: 538- 578.

Epstein, S., Buchsbaum, R., Lowenstam, H. A., and Urey, H. C., 1953. Revised carbonate-water isotopic temperature scale, Geol. Soc. Am. Bull., 64, 1315- 1325.

Faure, G., 1998. Principles and applications of geochemistry: a comprehensive textbook for geology students (2nd ed.). Englewood Cliffs, New Jersey: Prentice Hall.

Fisher, C.G., and Arthur, M.A., 2002. Water mass characteristics in the Cenomanian US Western Interior seaway as indicated by stable isotopes of calcareous organisms. Palaeogeography, Palaeoclimatology, Palaeoecology, 188: 189-213.

Frakes, L.A., 1999. Estimating the global thermal state from Cretaceous sea surface and continental temperature data, In Barrera, E., and Johnson, C.C., (Eds.), Evolution of the Cretaceous Ocean-Climate System, Spec. Pap. Geol. Soc. Am., 332: 49- 57.

Galeotti, S., Bellagamba, M., Kaminski, M.A., and Montanari, A., 2002. Deep-sea benthic foraminiferal recolonisation following a volcaniclastic event in the lower Campanian of the Scaglia Rossa Formation (Umbria-March Basin, central Italy). Marine Micropaleontology 44: 57-76.

Gill, J.R., and Cobban, W.A., 1973. Stratigraphy and geologic history of the Montana Group and equivalent rocks, Montana, Wyoming, and North and South Dakota. U.S. Geological Survey Professional Paper, 776: 37. 
Graham, D. W., Corliss, B. H., Bender, M. L., and Keigwin Jr., L. D., 1981. Carbon and oxygen isotopic disequilibria of recent deep-sea benthic foraminifera, Mar. Micropaleontology., 6: $483-497$.

Haq, B.U., Hardenbol, J., and Vail, P.R. 1987. Chronology of fluctuating sea levels since the Triassic. Science, 235: 1156-1166.

Hasegawa, T., 1997. Cenomanian-Turonian carbon isotope events recorded in terrestrial organic matter from northern Japan. Palaeogeography, Palaeoclimatology, Palaeoecology, 130: 251-273.

He, S., Kyserb, T.K., and Caldwell, W.G.E., 2005. Paleoenvironment of the Western Interior Seaway inferred from $\delta^{18} \mathrm{O}$ and $\delta^{13} \mathrm{C}$ values of molluscs from the Cretaceous Bearpaw marine cyclothem. Palaeogeography, Palaeoclimatology, Palaeoecology, 217: 67-85.

Hotinski, R., Bice, K. L., Kump, L. R., Najjar, R. G., and Arthur, M. A., 2001. Ocean stagnation and end-Permian anoxia. Geology 29: 7-10.

Hudson, J.D., and Anderson, T.F., 1989. Ocean temperatures and isotopic compositions through time. Trans R Soc Edinb, 80: 183-192.

Jeletzky, J.A. 1971. Marine Cretaceous biotic provinces and paleogeography of western and Arctic Canada illustrated by a detailed study of ammonites. Geological Survey of Canada, Paper 70-22: 92.

Jenkyns, H.C., 1980. Cretaceous anoxic events: From continents to oceans: Journal of the Geological Society of London, 137: 171-188.

Jenkyns, H.C., 1985. The early Toacian and Cenomanian-Turonian anoxic events in Europe: comparisons and contracts. Geologische Rundschau 74: 505-518.

Karbashewski, D., 2006. Stable Isotope Geochemistry and Paleoclimate Changes across Mid-Cretaceous Bentonites: Vermilion River, Dauphin Manitoba, B.Sc. Honor thesis, University of Ottawa.

Kauffman, E.G., 1975. Dispersal and biostratigraphic potential of Cretaceous benthonic Bivalvia in the western interior. In Caldwell, W.G.E., (Ed.), The Cretaceous System in the western interior of North America. Geological Association of Canada, Special Paper 13: 163-194.

Kauffman, E.G., 1977. Geological and biological overview: Western Interior Cretaceous basin. Mountain Geologist, 14: 75-99.

Kauffman, E.G., 1984. Paleobiogeography and evolutionary response dynamic in the Cretaceous Western Interior Seaway of North America. In Westermann, G.E.G., (Ed.), Jurassic-Cretaceous Biochronology and Paleogeography of North America. Geol. Assoc. Can. Spec. (27): 273-306.

Kauffman, E.G. and Caldwell, W.G.E. 1994. The Western Interior Basin in space and time. In Caldwell, W.G.E., and Kauffman, E.G., (Eds.), Evolution of the Western Interior Basin; Geological Society of Canada, Special Paper, (39): 1-25

Keller, G. and Pardo, A., 2004. Paleoecology of the Cenomanian-Turonian Stratotype Section (GSSP) at Pueblo, Colorado. Marine Micropleontology, 51: 95-128.

Keller, G., Li, L. and MacLeod, N., 1995. The Cretaceous/Tertiary boundary stratotype section at El Kef, Tunisia: How catastrophic was the mass extinction? Paleogeogr., Paleoclimatol., Paleoecol., 119: 221-254.

Keller, G., 2003. Biotic effects of impacts and volcanism. Earth and Planetary Science Letters 215: 249-264. 
Kerr A.C., 1998. Oceanic plateau formation: a cause of mass extinction and black shale deposition around the Cenomanian - Turonian boundary? Journal of the Geological Society of London 155: 619 - 626.

Knechtel, M.M., and Patterson, S.H., 1956. Bentonite deposits in marine Cretaceous formations, Hardin District, Montana and Wyoming: U.S. Geological Survey Bulletin 1023: 116

Knechtel, M.M., and Patterson, S.H., 1962. Bentonite deposits of the northern Black Hills District, Wyoming, Montana, and South Dakota: U.S. Geological Survey Bulletin 1082-M: 893-1030.

Kyser, T.K., Caldwell, W.G.E., Whittaker S.G., and Cadrin A.J., 1993. Paleoenvironment and geochemistry of the northern portion of the Western Interior Seaway during Late Cretaceous time. In Caldwell, W.G.E., and Kauffman, E.G., (Eds.), Evolution of the Western Interior Basin; Geological Society of Canada, 39: 355-378.

Leckie, R.M., 1987. Paleoecology of mid-Cretaceous planktonic foraminifera: a comparison of open ocean and Epicontinental Sea assemblages. Micropaleontology, 33: $164-176$.

Leckie, R.M., Yuretich, R.F., West, O.L., Finkelstein, D., Schmidt, M., 1998. Paleoceanography of the southwestern Western Interior Sea during the time of the Cenomanian-Turonian Boundary (Late Cretaceous). In: Dean, W.E., Arthur, M.A. (Eds.), Stratigraphy and Paleoenvironments of the Cretaceous Western Interior Seaway, USA. SEPM Concepts in Sedimentology and Paleontology, 6: 101-126.

Leckie, D.A., Bhattacharya, J.P., Bloch, J., Gilboy, C.F., and Norris, B., 1994. Cretaceous Colorado/Alberta Group of Western Canada Sedimentary Basin. In Mossop, G.D., and Shetsen, I., (Eds.), Geological Atlas of Western Canada Sedimentary Basin, : 335-352. Canadian Society of Petroleum Geologists and Alberta Research Council, Calgary.

Leckie, R.M., Bralower, T.J., Cashman, R., 2002. Oceanic anoxic events and plankton evolution: Biotic response to tectonic forcing during the mid-Cretaceous. Paleoceanography 17:PA000623.

Lee, M.Y., Chen C.H., Wei, K.Y., Iizuka, Y., and Creay, S., 2004. First Toba supereruption revival. Geology, 32: 61-64

Lowenstam, H.A., and Epstein, S., 1954. Paleotemperatures of the post-Aptian Cretaceous as determined by the oxygen isotope method. Jour. Geol., 62(3): 207248.

Loydell, D.K., and Fryda, J., 2007. Carbon isotope stratigraphy of the upper Telychian and lower Sheinwoodian (Llandovery-Wenlock, Silurian) of the Banwy River section, Wales Geological Magazine 144: 1015-1019.

MacLeod, K.G., and Hoppe, K.A., 1992. Evidence that inoceramid bivalves were benthic and harbored chemosynthetic symbionts. Geology, 20: 17-120.

McCorkle, D.C., Keigwin, L.D., Corliss, B.H., and Emerson, S.R., 1990. The influence of microhabitats on the carbon isotopic composition of deep sea benthic foraminifera, Paleoceanography, 5(2): 161-185.

McNeil, D.H., and Caldwell, W.G.E., 1981. Cretaceous rocks and their foraminifera in the Manitoba Escarpment. Geological Association of Canada Special Paper 21: 439. 
McNeil, D.H., 1984. The eastern facies of the Cretaceous System in the Canadian Western Interior. In Stott, D.F., and Glass, D.J., (Eds.), The Mesozoic of Middle North America. Canadian Society of Petroleum Geologists, Memoir (9): 145-171.

Nichols, T.C., Jr., Chleborad, A.F., and Collins, D.S., 1987. Government Draw Bentonite Beds-A newly identified stratigraphic marker in the Virgin Creek Member of the Pierre Shale, central South Dakota: Mountain Geologist, 24: 77-80.

Nielsen, K.S., Schröder-Adams, C.J., Leckie, D.A., Haggart, J.W. and Elberdak, K., 2008. Turonian to Santonian paleoenvironmental changes in the Cretaceous Western Interior Sea: The Carlile and Niobrara formations in southern Alberta and southwestern Saskatchewan, Canada. Palaeogeography, Palaeoclimatology, Palaeoecology, 270: 64-91.

Obradovich, J.D., and Cobban, W.A., 1975, A time scale for the Late Cretaceous of the western interior of North America. In Caldwell, W.G.E., (Ed.), The Cretaceous System in the western interior of North America. Geological Society of Canada Special Paper (13) 31-54.

O’Neil, J. R., Clayton, R. N., and Mayeda, T. K., 1969. Oxygen isotope fractionation in divalent metal carbonates, J. Chem. Phys., 51(12), 5547-5558.

Prokoph, A., Fowler A.D., and Patterson, R.T., 2000. Evidence for periodicity and nonlinearity in a high-resolution fossil record of long-term evolution. Geology 28:867-870.

Prokoph, A., Villeneuve, M., Agterberg, F.P., and Rachold, V., 2001. Geochronology and calibration of global Milankovitch cyclicity at the Cenomanian-Turonian boundary. Geology, 29(6):523-526.

Rampino, M.R., Self, S., 1992. Volcanic winter and accelerated glaciation following the Toba super-eruption. Nature 359, 50-52.

Rampino, M.R., Self, S., 1993. Climate-volcanism feedback and the Toba eruption of $\sim 74,000$ Years ago. Quaternary Research 40, 269-280.

Rampino, M.R. and Self S., 1993b. "Bottleneck in human evolution and the Toba eruption." Science 262:1955.

Rink, S., Kuhl, M., Bijma, J., and Spero, H.J., 1998. Microsensor studies of photosynthesis and respiration in the symbiotic foraminifer Orbulina universa, Mar. Biol., 131: 583- 595.

Sageman, B.B., and Hollander, D.J., 1999. Integration of paleoecological and geochemical proxies: a holistic approach to the study of past global change. In: Johnson, C.J., and Barrera, E., eds., The Evolution of Cretaceous Ocean/Climate Systems. Geological Society of America, Special Paper 332, p. 365-384.

Schlanger, S.O., and Jenkyns, H.C., 1976, Cretaceous oceanic anoxic events: Causes and consequences: Geologie en Mijnbouw, v. 55, p. 179-184.

Schlanger, S.O., Arthur, M.A., Jenkyns, H.C., and Scholle, P.A., 1987. The CenomanianTuronian oceanic anoxic event, I, Stratigraphy and distribution of organic carbonrich beds and the marine delta $\left(\delta^{13} \mathrm{C}\right.$ excursion in Marine petroleum source rocks. In Brooks, J., and Fleet, A.J. (eds.), Geological Society of London Special Publications 26, pp. 371-399.

Scholle, P.A., Arthur, M.A., 1980. Carbon-isotope fluctuations in Cretaceous pelagic limestones; potential stratigraphic and petroleum exploration tool. AAPG Bulletin $64,67-87$. 
Schönfeld, J., Sirocko, F., and Jørgensen, N.O., 1991. Oxygen isotope composition of Upper Cretaceous chalk at Lägerdorf (NW Germany): its original environmental signal and paleotemperature interpretation, Cretac. Res. 12 (1991), pp. 27-46.

Schröder-Adams, C.J., Leckie, D.A., Bloch, J., Craig, J., McIntyre, D.J. \& Adams, P.J. 1996. Paleoenvironmental changes in the Cretaceous (Albian to Turonian) Colorado Group of western Canada: microfossil, sedimentological and geochemical evidence. Cretaceous Research, 17, 311-365.

Schröder-Adams, C.J., S.L. Cumbaa, J. Bloch, D.A. Leckie, J. Craig, S.A.S. El-Dein, D.J.H.A.E. Simons, and F. Kenig. 2001. Late Cretaceous (Cenomanian to Campanian) paleoenvironmental history of the eastern Canadian margin of the Western Interior Seaway: bonebeds and anoxic events. Palaeogreography, Palaeoclimatology, Palaeoecology 170:261-289.

Simons, D.-J.H., Kenig, F. and Schröder-Adams, C.J., (2003). An organic geochemical study of Cenomanian-Turonian sediments from the Western Interior Seaway, Canada. Organic Geochemistry, 34: 1177-1198.

Simpson, F. 1982. Sedimentology, palaeoecology and economic geology of Lower Colorado (Cretaceous) strata of west-central Saskatchewan. Saskatchewan Energy and Mines, Saskatchewan Geological Survey, Report 150, 183 p.

Singh, C. 1983. Cenomanian microfloras of the Peace River area, northwestern Alberta. Alberta Research Council, Bulletin 44, 322 p.

Slaughter, M., and Earley, J.W., 1965. Mineralogy and geological significance of the Mowry bentonites, Wyoming: Geological Society of America Special Paper 83, 116 p.

Stoll, H.M. and Schrag, D.P., 2000. High-resolution stable isotope records from the Upper Cretaceous rocks of Italy and Spain: Glacial episodes in a greenhouse planet? GSA Bulletin; v. 112; no. 2; p. 308-319.

Stothers, R. B., 1993. Flood basalts and extinction events. Geophysical Research Letters 20, 1399-1402.

Stott, D.F. 1963. The Cretaceous Alberta Group and equivalent rocks, Rocky Mountain Foothills, Alberta. Geological Survey of Canada, Memoir 317, 306 p.

Stott, D.F. 1967. The Cretaceous Smoky Group, Rocky Mountain Foothills, Alberta and British Columbia. Geological Survey of Canada, Bulletin 132, 133 p.

Stott, D.F. 1982. Lower Cretaceous Fort St. John Group and Upper Cretaceous Dunvegan Formation of the Foothills and Plains of Alberta, British Columbia, District of Mackenzie and Yukon Territory. Geological Survey of Canada, Bulletin 328, 124 p.

Tantawy, A. A. Keller, G. Pardo, A., 2009. Late Maastrichtian Volcanism in the Indian Ocean: Effects on Calcareous Nannofossils and Planktic Foraminifera. Palaeogeography, Palaeoclimatology, Palaeoecology, Volume 284, Issues 1-2, Pages 63-87.

Tu, Q., Schröder-Adams, C.J. and Craig, J., 2007. A new lithostratigraphic framework for the Cretaceous Colorado Group in the Cold Lake heavy oil area, East-Central Alberta, Canada. Natural Resources Research, v. 16(1), p. 17-30.

H.G. Urey, The thermodynamic properties of isotopic substances, Journal of the Chemical Society 1 (1947), pp. 562-581. 
Villeneuve, M., Ross, G., Theriault, R., Miles, W., Parrish, R., and Broome, J., 1993. Tectonic subdivision and U-Pb geochronology of the crystalline basement of the Alberta basin, western Canada: Geological Survey of Canada Bulletin 447, 86 p.

Wan, X., Weib, M., and Li, G., 2003. $\delta^{13} \mathrm{C}$ values from the Cenomanian-Turonian passage beds of southern Tibet. Journal of Asian Earth Sciences 21(8): 861-866.

Williams, G.D. and Burk, C.F. 1964. Upper Cretaceous. In: Geological History of Western Canada. R.G. McCrossan and R.P. Glaister (eds.). Alberta Society of Petroleum Geologists, p. 169-189.

Wolf-Gladrow, D. A., Bijma, J., and Zeebe, R.E., 1999. Model simulation of the carbonate system in the microenvironment of symbiont bearing foraminifera. Mar. Chem., 64: $181-198$.

Zeebe, R. E., Bijma, J., and Wolf-Gladrow, D.A., 1999. A diffusion-reaction model of carbon isotope fractionation in foraminifera. Mar. Chem., 64: 199- 227. 


\section{APPENDICES}




\section{Appendix A: Geochemical Tables}

Appendix A 1: Geochemical data table for Vermilion River V1. Data originally acquired by Prokoph, 2001 except those with gray background acquired in this study.

\begin{tabular}{|c|c|c|c|c|c|c|}
\hline sample/No. & depth & TOCC & $\mathrm{CaCO}_{3}$ & $\delta^{18} O$ & $\delta^{13} \mathrm{C}$ & $\delta^{13} C_{\text {aro }}$ \\
\hline V1 & 1.95 & 0.55 & 74.96 & -6.92 & 0.13 & -25.41 \\
\hline $\mathrm{V} 2$ & 2.1 & & & -5.07 & -0.89 & -26.35 \\
\hline V3 & 2.25 & 7.05 & 67.11 & -7.51 & 0.55 & -27.15 \\
\hline V4 & 2.5 & 4.28 & 48.38 & -7.27 & 2.77 & -23.94 \\
\hline V5 & 3.3 & 6.45 & 70.07 & -7.92 & 0.96 & -25.94 \\
\hline V6 & 3.8 & 4.69 & 47.08 & -4.96 & -2.85 & -27.43 \\
\hline V7 & 4.1 & 2.00 & 83.17 & -5.80 & 0.67 & -26.77 \\
\hline V8 & 4.4 & 7.62 & 45.03 & -8.63 & 0.62 & -26.93 \\
\hline V9 & 5.1 & 4.58 & 68.05 & -7.69 & 1.95 & -26.78 \\
\hline V10 & 5.5 & 4.43 & 72.26 & -6.82 & 0.55 & -28.49 \\
\hline $\mathrm{V} 12$ & 6.9 & 7.34 & 45.29 & -8.60 & 1.42 & -27.82 \\
\hline V13 & 7.9 & 5.63 & 67.48 & -7.94 & 0.58 & -28.21 \\
\hline V14 & 8.2 & 7.78 & 40.45 & -10.08 & 0.69 & -28.05 \\
\hline V15 & 8.5 & 6.71 & 56.51 & -8.23 & 0.47 & -28.65 \\
\hline V16 & 8.8 & 6.88 & 49.06 & -9.82 & 0.43 & -27.11 \\
\hline V17 & 9 & 6.76 & 59.15 & -8.26 & 0.81 & -28.42 \\
\hline V18 & 9.1 & 8.98 & 47.76 & -8.49 & 0.88 & -28.58 \\
\hline V19 & 9.6 & 7.18 & 64.06 & -9.14 & -1.55 & -27.76 \\
\hline $\mathrm{V} 20$ & 10.1 & 7.08 & 58.46 & -7.76 & -0.19 & -27.57 \\
\hline S 21 & 10.4 & 11.16 & & -4.5 & -2.96 & -28.28 \\
\hline $\mathrm{S} 20$ & 10.45 & 9.27 & & -3.83 & -2.88 & -27.45 \\
\hline S19 & 10.5 & 4.53 & & -4.4 & -3.73 & -28.51 \\
\hline S18 & 10.55 & 10 & & -5.66 & -5.58 & -28.05 \\
\hline S17 & 10.6 & 12.19 & & -7.59 & -2.64 & -28.29 \\
\hline V21 & 10.85 & 7.54 & 37.58 & -8.28 & 1.21 & -27.55 \\
\hline S16 & 10.9 & 10.45 & & -7.64 & -3.04 & -28.23 \\
\hline S15 & 10.95 & 9.07 & & -7.38 & -3.24 & -27.94 \\
\hline S14 & 11 & 6.3 & & -3.77 & -4.38 & -27.4 \\
\hline $\mathrm{S} 13$ & 11.05 & 5.91 & & -4.58 & -3.03 & -27.6 \\
\hline V22 & 11.1 & & & & & \\
\hline S12 & 11.2 & 10.93 & & -7.48 & -2.67 & -27.61 \\
\hline V23 & 11.3 & 8.03 & 40.47 & -8.36 & -0.05 & -26.71 \\
\hline S11 & 11.4 & 8.75 & & -7.27 & -2.9 & -27.66 \\
\hline V24 & 13.8 & 6.17 & 0.38 & -12.26 & 4.22 & -27.28 \\
\hline V25 & 15.8 & 4.92 & 0.00 & & & -27.81 \\
\hline V26 & 16.85 & 4.47 & 0.00 & & & -27.77 \\
\hline $\mathrm{S} 10$ & 16.9 & 6.49 & & & & -28.24 \\
\hline S9 & 17.1 & 4.11 & & & & -28.22 \\
\hline S8 & 17.2 & 1.91 & & & & -28.47 \\
\hline $\mathrm{V} 27$ & 17.28 & 0.83 & 26.26 & -8.72 & 0.69 & -27.56 \\
\hline S6 & 17.3 & 0.67 & & & & -28.25 \\
\hline S5 & 17.45 & 1.29 & & & & -26.92 \\
\hline S4 & 17.5 & 0.74 & & & & -28.68 \\
\hline V28 & 17.8 & & & & & \\
\hline S3 & 17.9 & 0.72 & & & & -27.92 \\
\hline V29 & 18.05 & 0.26 & 90.52 & -7.72 & -1.07 & -26.70 \\
\hline S2 & 18.1 & 0.82 & & & & -27.95 \\
\hline V30 & 18.25 & 0.46 & 85.97 & -10.17 & 0.00 & -28.15 \\
\hline S1 & 18.3 & 1.14 & & & & -28.67 \\
\hline
\end{tabular}




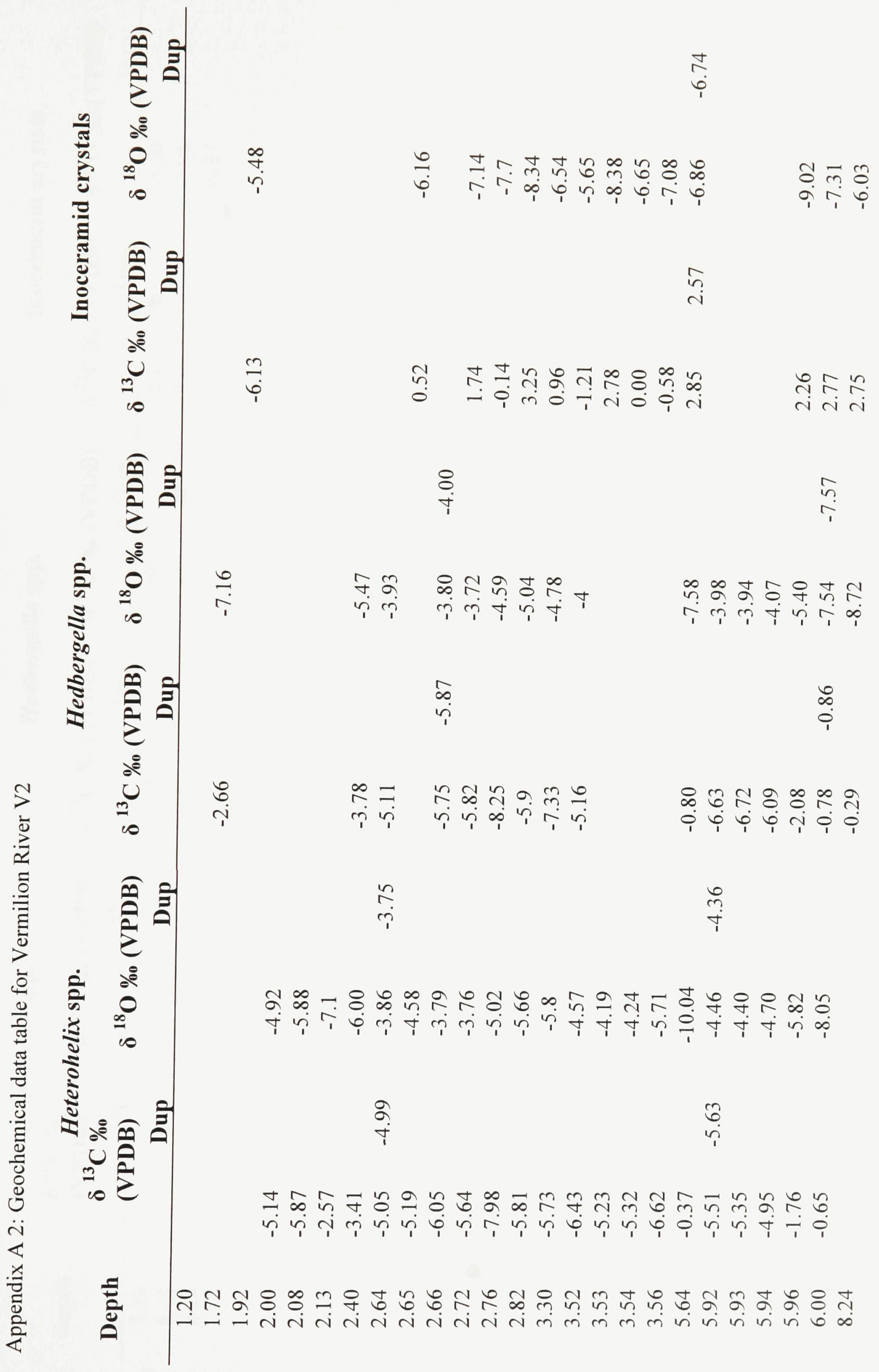




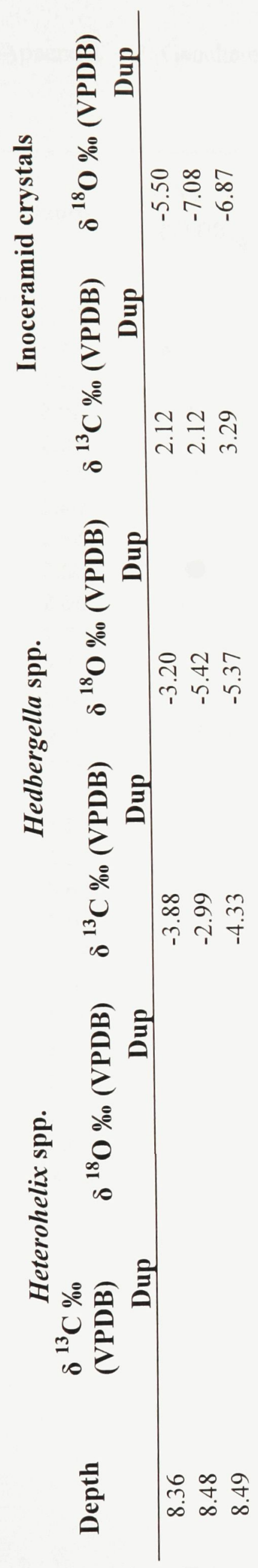


Appendix A 3: Geochemical data table for Vermilion River V2 (Continuation)

Bulk Rock (Organic)

\begin{tabular}{|c|c|c|c|c|c|c|c|}
\hline Depth & $\begin{array}{c}\delta^{13} C_{\text {org }} \% \\
\text { (VPDB) }\end{array}$ & $\delta^{15} \mathrm{~N}$ air & $\% C$ & $\% N$ & S\% & $\begin{array}{l}\text { N \% } \\
\text { Re-a }\end{array}$ & C \% \\
\hline 1.20 & -26.34 & -1.06 & 5.71 & 0.23 & 2.15 & 0.20 & 5.69 \\
\hline 1.72 & -27.01 & -1.47 & 6.42 & 0.23 & 3.18 & 0.24 & 6.67 \\
\hline 1.92 & -26.64 & -1.20 & 5.98 & 0.20 & 4.89 & 0.21 & 6.17 \\
\hline 2.00 & -26.68 & -1.20 & 5.89 & 0.20 & 4.79 & 0.21 & 5.88 \\
\hline 2.08 & -26.47 & -1.12 & 6.30 & 0.21 & 4.13 & 0.23 & 6.28 \\
\hline 2.13 & -26.13 & -1.17 & 6.13 & 0.19 & 4.48 & 0.22 & 6.33 \\
\hline 2.40 & -26.73 & -1.48 & 7.48 & 0.26 & 3.73 & 0.30 & 7.86 \\
\hline 2.64 & -26.84 & -1.48 & 13.26 & 0.43 & 2.32 & 0.51 & 14.83 \\
\hline 2.65 & -26.78 & -1.64 & 15.78 & 0.52 & 3.22 & 0.56 & 16.17 \\
\hline 2.66 & -26.81 & -1.60 & 15.62 & 0.50 & 1.55 & 0.55 & 16.16 \\
\hline 2.72 & -27.04 & -1.35 & 7.29 & 0.25 & 2.19 & 0.29 & 7.94 \\
\hline 2.76 & -26.75 & -1.80 & 4.42 & 0.14 & 2.26 & 0.14 & 4.26 \\
\hline 2.82 & -27.29 & -1.98 & 6.06 & 0.18 & 0.95 & 0.22 & 6.30 \\
\hline 3.30 & -27.28 & -1.59 & 14.95 & 0.44 & 4.60 & 0.55 & 16.37 \\
\hline 3.52 & -27.10 & -1.75 & 22.32 & 0.67 & 4.40 & 0.72 & 21.42 \\
\hline 3.53 & -27.12 & -1.64 & 17.01 & 0.54 & 4.03 & 0.59 & 16.71 \\
\hline 3.54 & -27.19 & -1.60 & 22.04 & 0.68 & 3.62 & 0.75 & 22.14 \\
\hline 3.56 & -27.37 & -1.22 & 14.59 & 0.47 & 3.80 & 0.52 & 14.73 \\
\hline 5.64 & -26.49 & -2.38 & 10.11 & 0.34 & 2.06 & 0.43 & 11.94 \\
\hline 5.92 & & -1.74 & 12.26 & 0.19 & 0.57 & 0.26 & 12.78 \\
\hline 5.93 & & -2.06 & 15.63 & 0.40 & 2.28 & 0.52 & 18.31 \\
\hline 5.94 & & -3.32 & 18.15 & 0.38 & 0.86 & 0.40 & 17.32 \\
\hline 5.96 & -26.30 & -1.84 & 15.86 & 0.56 & 1.99 & 0.64 & 18.35 \\
\hline 6.00 & & -1.63 & & 0.29 & 1.16 & 0.43 & 12.80 \\
\hline 8.24 & -27.30 & -1.99 & 5.54 & 0.18 & 1.34 & 0.27 & 7.09 \\
\hline 8.36 & -26.94 & -2.17 & 11.03 & 0.38 & 2.36 & 0.42 & 11.27 \\
\hline 8.48 & -27.08 & -1.91 & 12.63 & 0.39 & 1.81 & 0.67 & 18.76 \\
\hline 8.49 & -26.56 & -1.86 & 20.28 & 0.65 & 2.92 & 0.70 & 19.03 \\
\hline
\end{tabular}


Appendix A 4: Geochemical data table for well 6-34-30-8w4 (Youngstown). Data originally acquired by Prokoph, 2001 except those with green background acquired in this study.

\begin{tabular}{|c|c|c|c|c|c|c|c|c|}
\hline \multirow{2}{*}{$\begin{array}{l}\text { Sample/No. } \\
1\end{array}$} & \multirow{2}{*}{$\begin{array}{c}\text { Depth } \\
679.9\end{array}$} & \multirow{2}{*}{$\frac{\mathrm{TOC}}{3.7}$} & \multirow{2}{*}{$\frac{\mathrm{CaCO}_{3}}{0.01}$} & \multirow{2}{*}{$\frac{\delta^{18} \mathbf{O}}{-13.93}$} & \multirow{2}{*}{$\frac{\delta^{13} \mathbf{C}}{-8.86}$} & \multirow{2}{*}{$\frac{\boldsymbol{\delta}^{13} \boldsymbol{C}_{\text {org }}}{-27.38}$} & \multicolumn{2}{|c|}{$\begin{array}{c}\text { Inoceramid } \\
\text { prisms }\end{array}$} \\
\hline & & & & & & & $\delta^{18} \mathrm{O}$ & $\delta^{13} \mathrm{C}$ \\
\hline $\begin{array}{l}2 \\
3\end{array}$ & $\begin{array}{c}680.6 \\
682\end{array}$ & 2.76 & 0.01 & & & -27.09 & & \\
\hline 4 & $\begin{array}{l}682 \\
687\end{array}$ & & & & & & & \\
\hline 5 & 687.8 & & & & & & & \\
\hline 6 & 691 & 3.26 & 0.01 & & & -27.13 & & \\
\hline 7 & 692.2 & 4 & 0.01 & & & -27.23 & & \\
\hline T1a & 693.22 & & & & & & & \\
\hline \multicolumn{9}{|l|}{ Bentonite } \\
\hline $\begin{array}{l}\text { Tlb } \\
8\end{array}$ & $\begin{array}{c}693.27 \\
693.3\end{array}$ & 4.12 & 1.58 & -7.61 & 2.05 & -26.98 & & \\
\hline $\mathrm{T} 2 \mathrm{a}$ & 693.8 & & & & & & & \\
\hline \multicolumn{9}{|l|}{ Bentonite } \\
\hline $\mathrm{T} 2 \mathrm{~b}$ & 693.9 & & & & & & & \\
\hline 9 & 694 & 3.97 & 0.92 & & & -26.89 & & \\
\hline 10 & 694.7 & 4.93 & 4.33 & -7.28 & 0.26 & -27.00 & & \\
\hline 11 & 695.8 & 4.6 & 4.08 & -8.36 & 0.27 & -26.96 & & \\
\hline T3a & 696.2 & & & & & & & \\
\hline \multicolumn{9}{|l|}{ Bentonite } \\
\hline $\mathrm{T} 3 \mathrm{~b}$ & 696.3 & & & & & & & \\
\hline 12 & 696.8 & 4.05325 & 1.92 & & & -27.13 & & \\
\hline 13 & 697.5 & 4.68 & 1.92 & & & -27.28 & & \\
\hline 14 & 698 & 4.0715 & 0.83 & & & -27.22 & & \\
\hline \multirow[t]{2}{*}{15} & 699.5 & 4.77 & 4.17 & -8.02 & -1.65 & -27.40 & & \\
\hline & 699.668 & & & & & & -6.37 & 1.9 \\
\hline 16 & 701 & 4.04 & 10.75 & -9.90 & -2.13 & -27.23 & & \\
\hline 17 & 702 & 4.97 & 4.08 & -11.07 & -1.78 & -27.38 & & \\
\hline \multirow[t]{2}{*}{18} & 703.3 & 6.26 & 3.58 & -7.59 & 0.10 & -27.26 & & \\
\hline & 703.758 & & & -11.45 & -4.09 & & & \\
\hline \multirow[t]{2}{*}{19} & 704.2 & 9.5 & 35.00 & -9.07 & 0.06 & -26.29 & -8.17 & 2.23 \\
\hline & 704.901 & & & -6.14 & 3.4 & & & \\
\hline \multirow[t]{2}{*}{20} & 705 & 5.24 & 36.67 & -8.54 & 0.98 & -26.73 & & \\
\hline & 705.307 & & & -6.64 & 2.58 & & -7.36 & 3.93 \\
\hline 21 & 705.5 & 5.4 & 34.58 & -6.94 & 1.48 & -26.39 & -6.56 & 3.43 \\
\hline $\mathrm{T} 4 \mathrm{a}$ & 705.55 & & & & & & & \\
\hline \multicolumn{9}{|l|}{ Bentonite-22 } \\
\hline \multirow[t]{2}{*}{$\mathrm{T} 4 \mathrm{~b}$} & 705.68 & & & & & & & \\
\hline & 705.993 & & 2983 & -12.04 & -3.92 & & & \\
\hline \multirow[t]{2}{*}{23} & 706.3 & 5.98 & & -8.72 & 0.92 & -25.69 & & \\
\hline & 706.526 & & 47.00 & $\begin{array}{l}-7.98 \\
-7.70\end{array}$ & 1.64 & -25.41 & -6.56 & 3.22 \\
\hline \multirow{2}{*}{24} & 707 & 6.76 & & -7.70 & -0.22 & & -8.9 & 2 \\
\hline & $\begin{array}{l}708.050 \\
708.914\end{array}$ & & & & & & & \\
\hline \multirow[t]{2}{*}{25} & 709 & 6.05 & 32.25 & -7.95 & 1.58 & -25.58 & & \\
\hline & 709.930 & & & -11.2 & -4.14 & & -8.43 & 4.25 \\
\hline 26 & 710 & 5.28 & 12.25 & -7.96 & 1.63 & -24.94 & & \\
\hline T5a & 710.2 & & & & & & & \\
\hline Bentonite & & & & & & & & \\
\hline
\end{tabular}




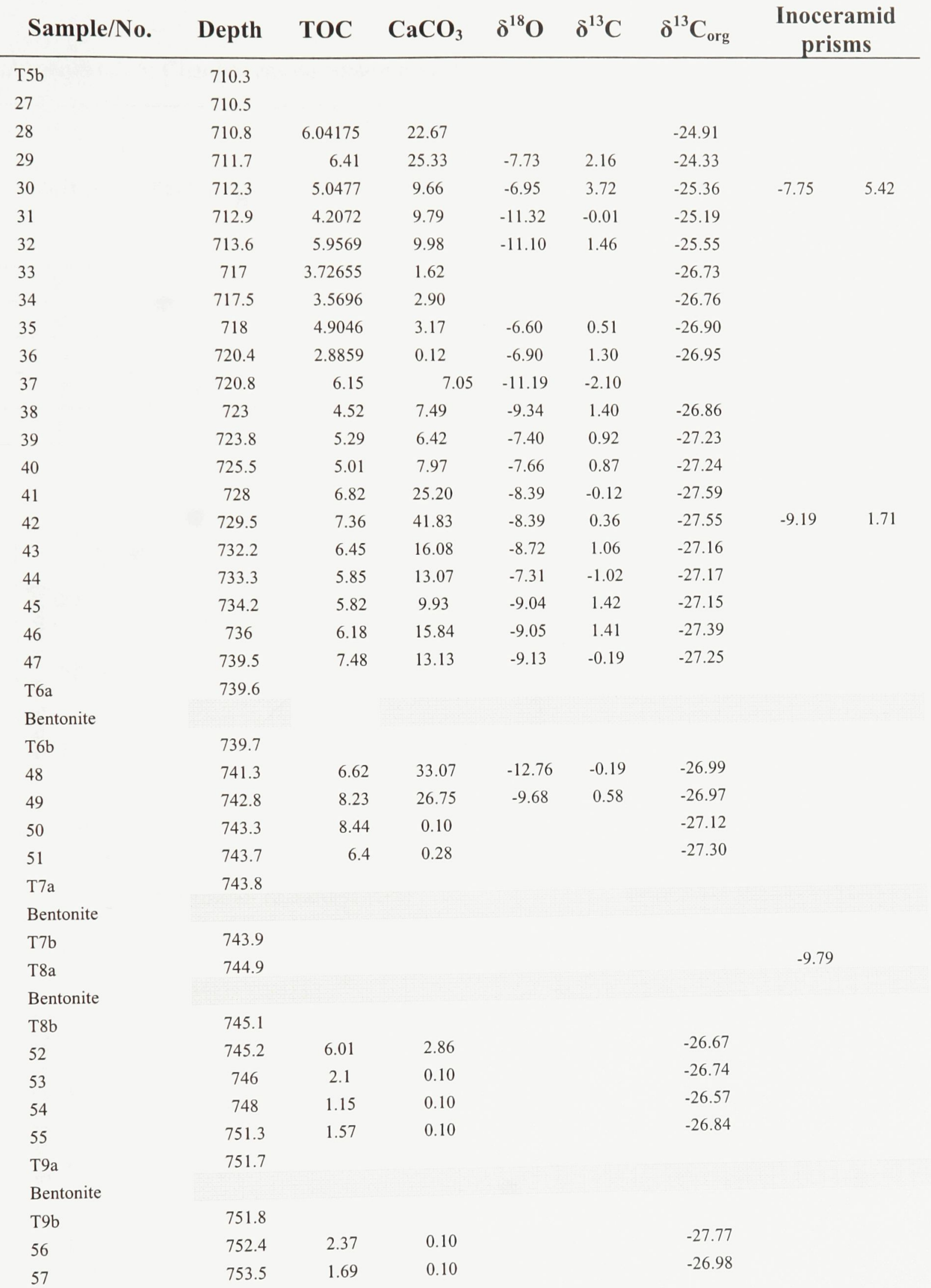


Appendix A 5: Changes across bentonites using other geochemical data.

\begin{tabular}{|c|c|c|c|c|c|}
\hline \multirow{2}{*}{ Interval } & \multirow{3}{*}{ Bentonite Thickness (cm) } & \multicolumn{4}{|c|}{ Changes Across Bentonites } \\
\cline { 3 - 6 } & & \multicolumn{4}{|c|}{ Bulk Rock } \\
\cline { 3 - 6 } & & $\boldsymbol{\Delta} \mathbf{N} \%$ & $\boldsymbol{\Delta} \mathbf{H} \%$ & $\boldsymbol{\Delta} \mathbf{S} \%$ & $\boldsymbol{\Delta} \boldsymbol{\delta}^{\mathbf{1 5}} \mathbf{N}_{\text {air }}$ \\
\cline { 3 - 6 } & & & & -1.71 & -0.27 \\
\hline B & 10 & -0.09 & 0.16 & 0.75 & 0.31 \\
\hline C & 2 & -0.17 & 0.02 & 0.20 & 0.16 \\
\hline D & 10 & 0.17 & 1.07 & 1.49 & -0.64 \\
\hline E & 5 & -0.15 & 3.76 & -1.03 & 0.18 \\
\hline F & 10 & & &
\end{tabular}
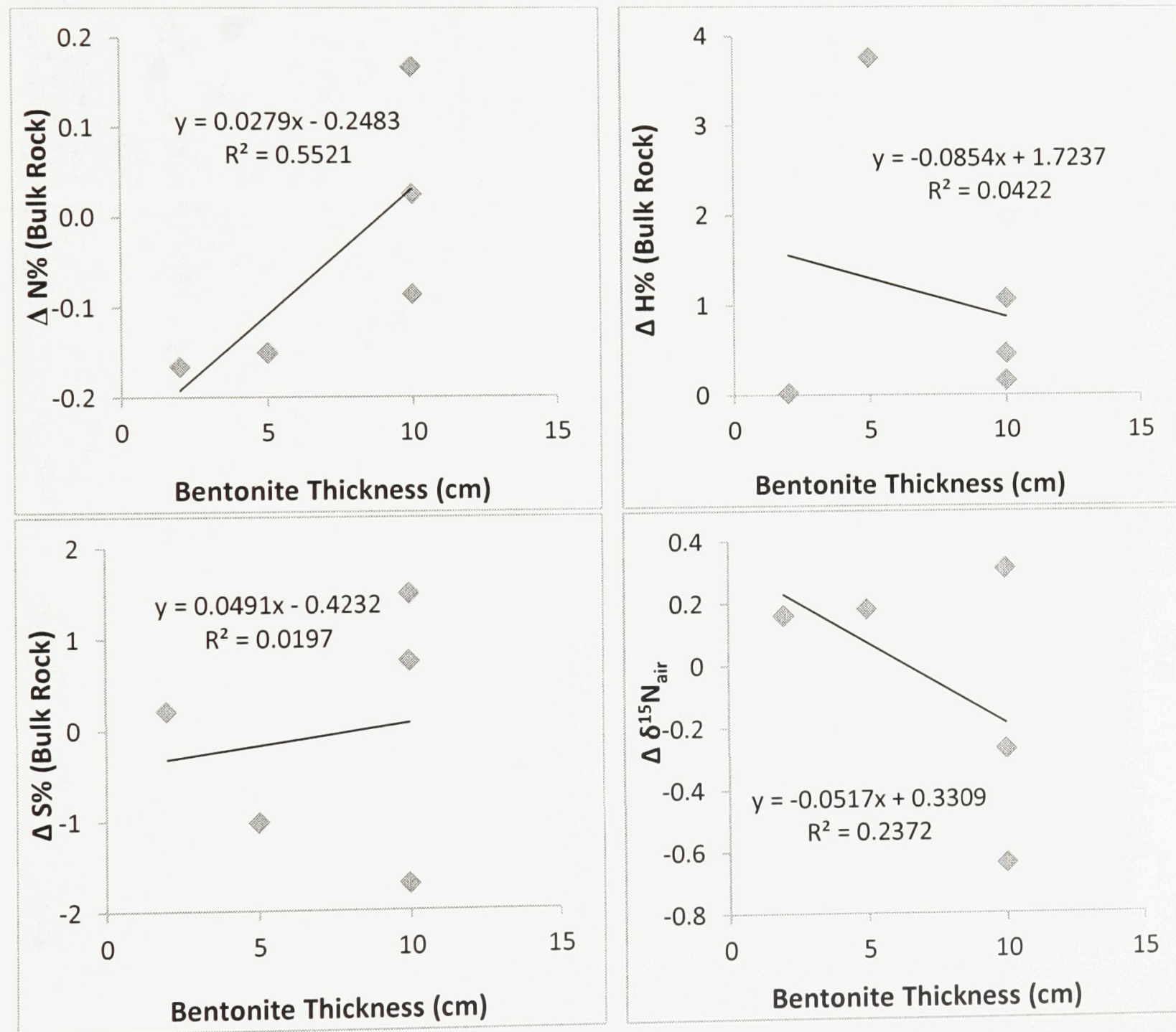
Appendix B: Plates
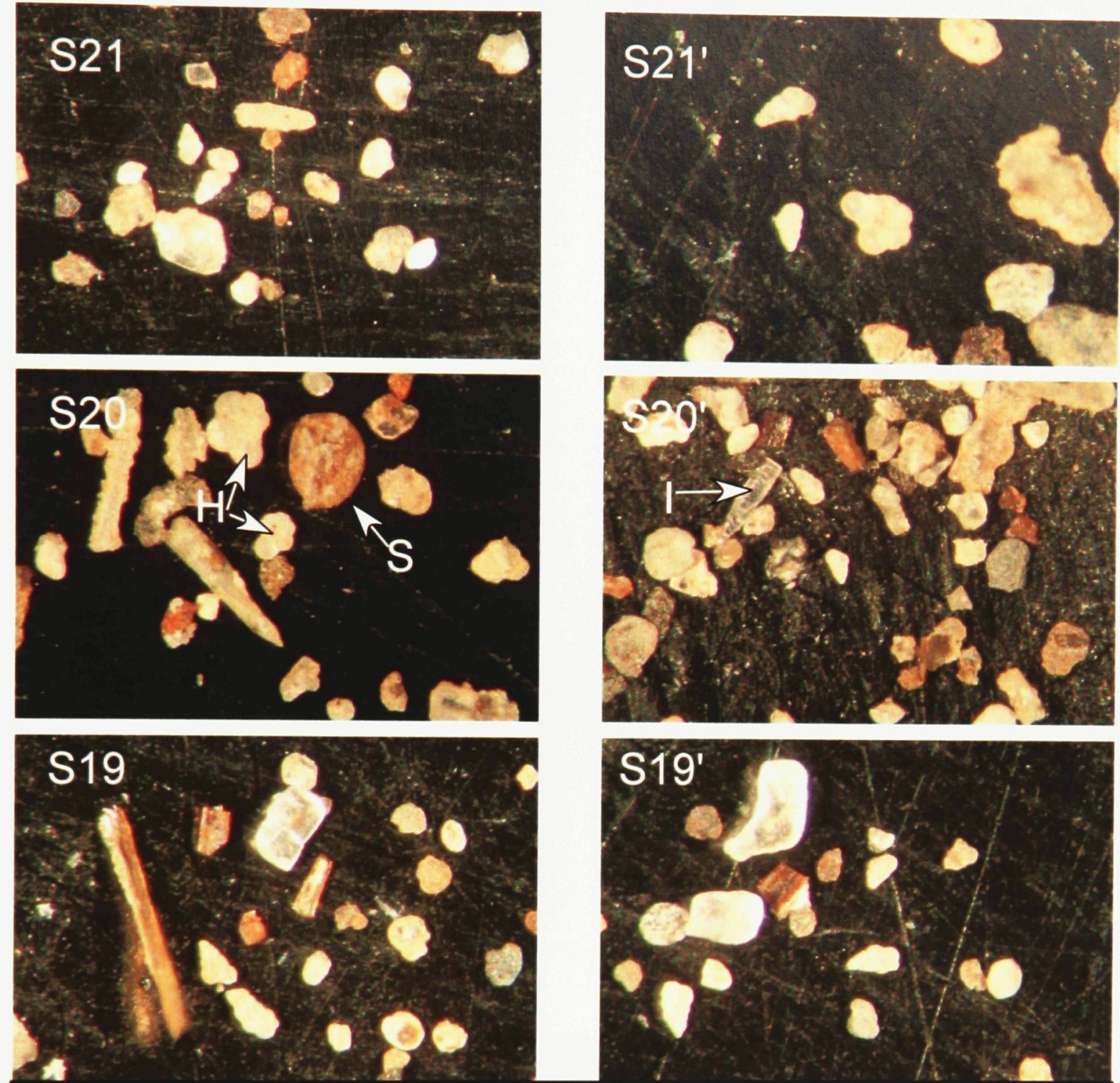

\section{Bentonite D}

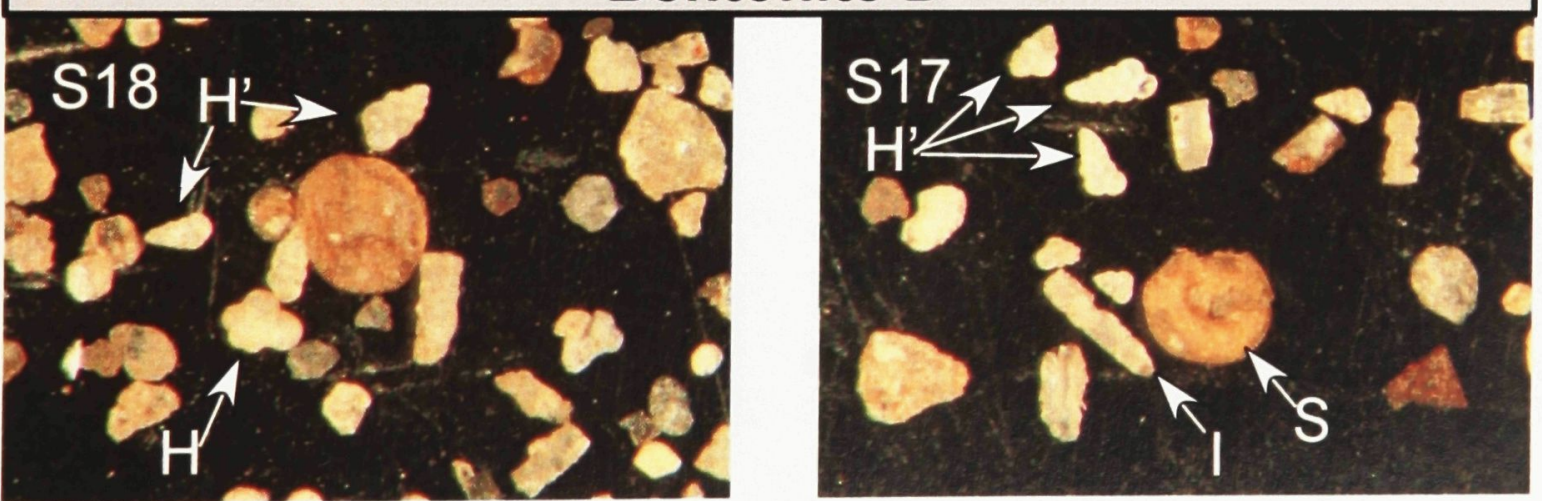

\section{$\overline{100 \mu \mathrm{m}}$}

Plate 1: Light-microscope image of residue samples across bentonite D from Vermilion River section V1. The residue consists of spores (S), inoceramid prisms (I) and some planktonic foraminiferal, mostly Heterohelix $\left(\mathrm{H}^{\prime}\right)$ and some Hedbergella sp. $(\mathrm{H})$ below the bentonite. The foraminifera are well preserved and the noticeable changes is the reduced number of Hedbergella sp. in plates S19 \& S19' immediately above bentonite $\mathrm{D}$. 

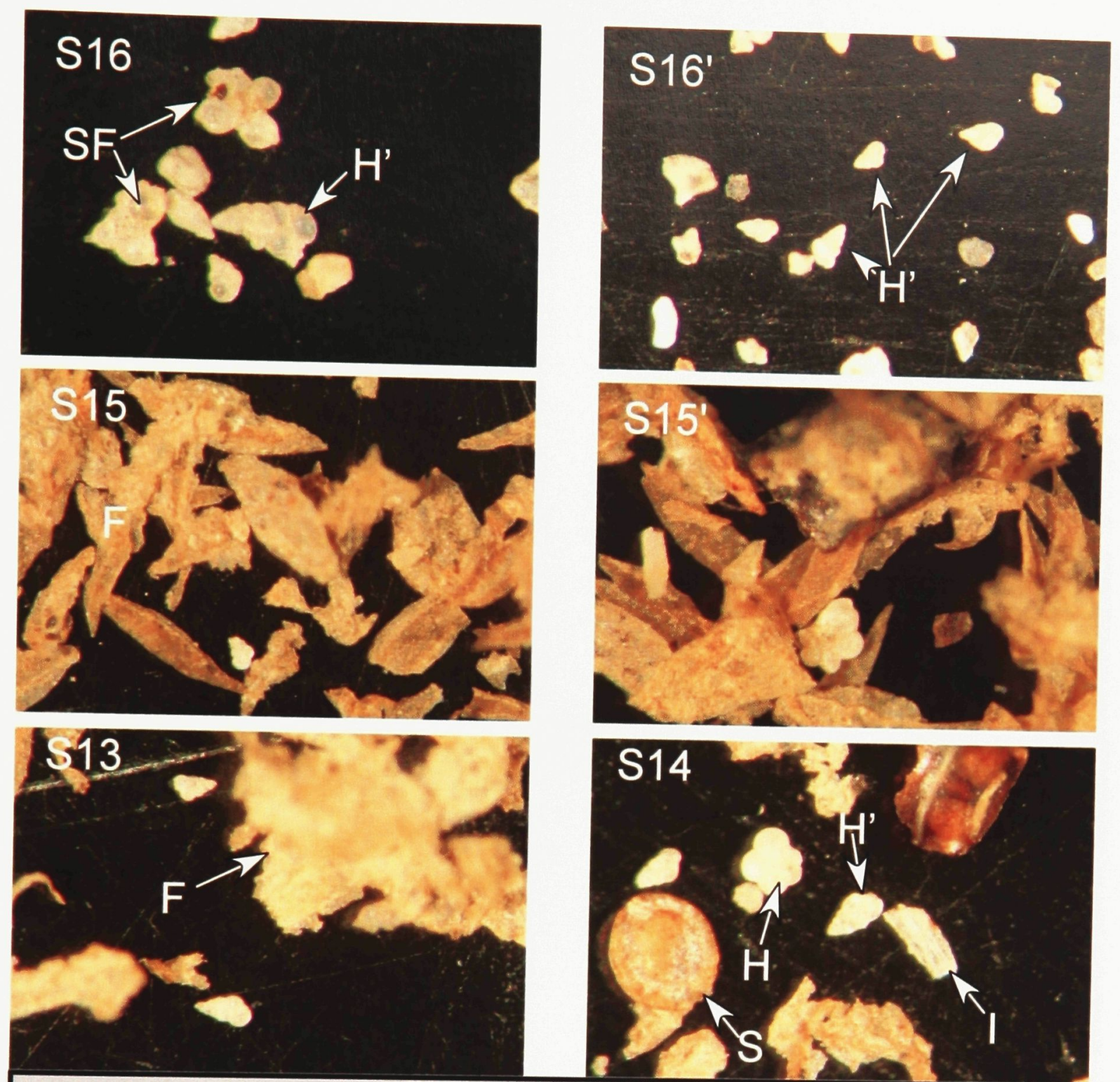

\section{Bentonite E}
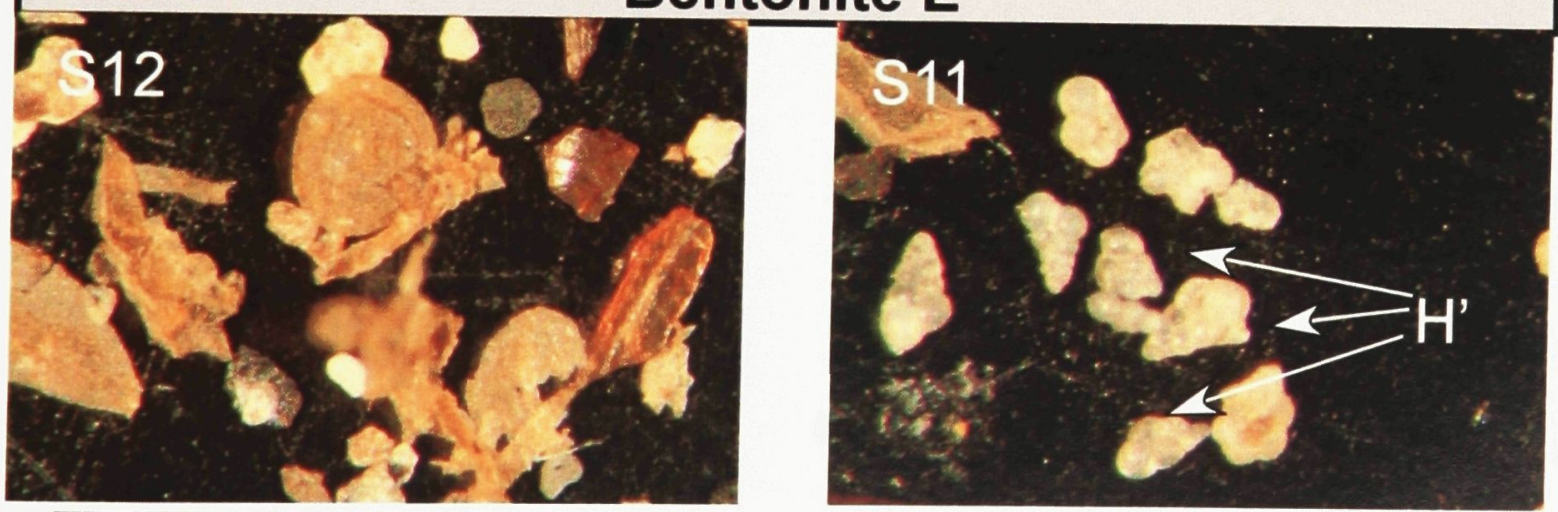

\section{$\overline{100 \mu \mathrm{m}}$}

Plate 2: Light-microscope image of residue samples across bentonite E from Vermilion River section V1. The residue contain fish remains (F) and some planktonic foraminiferal, mostly Heterohelix sp. (H') below the bentonite and some Hedbergella sp. $(\mathrm{H})$ at S14 and 15'. The foraminifera are well preserved, but no changes are discernible across the bentonite except the first appearance of the star shaped foraminifera 'SF' at S16. 

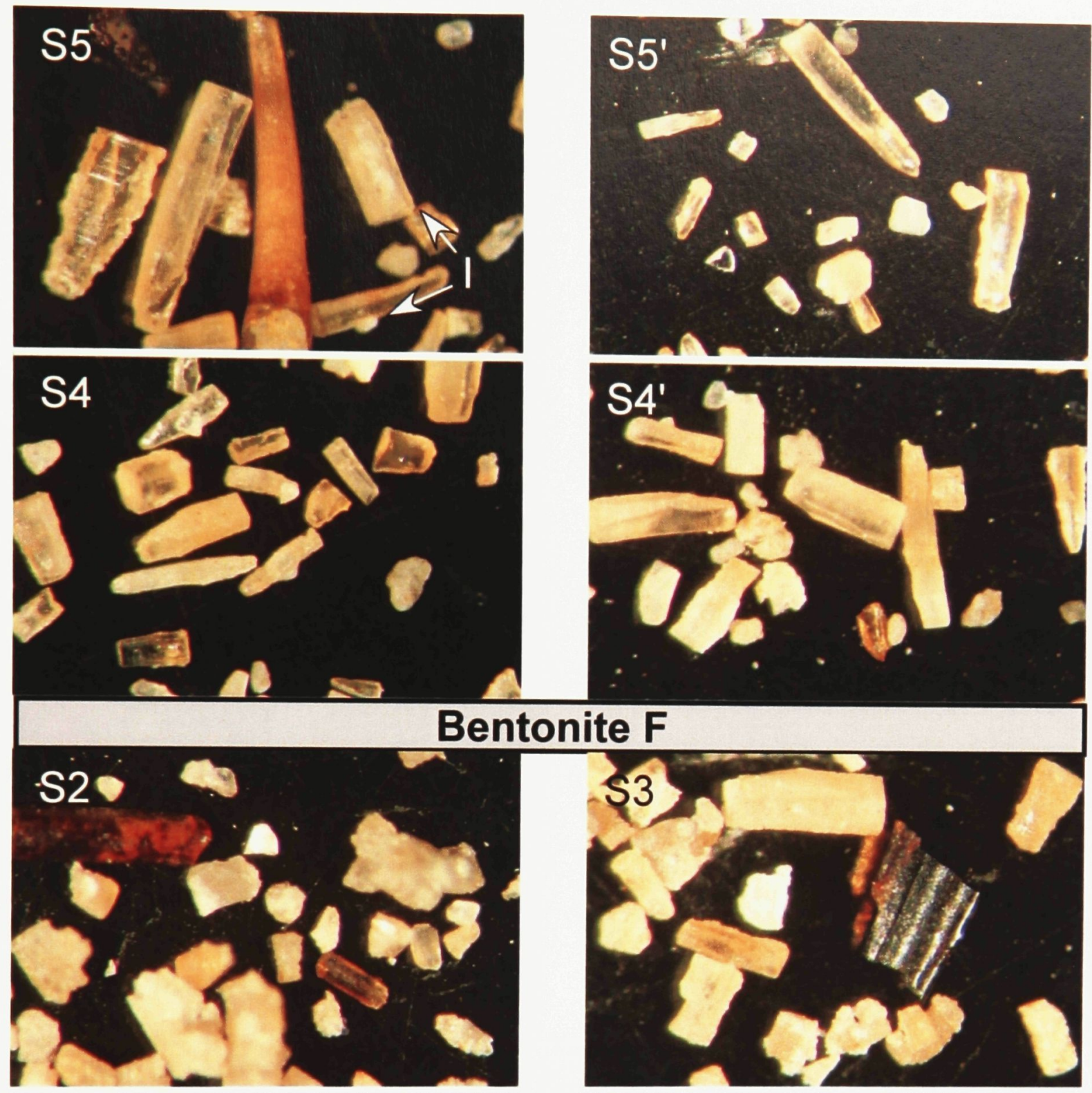

nite F
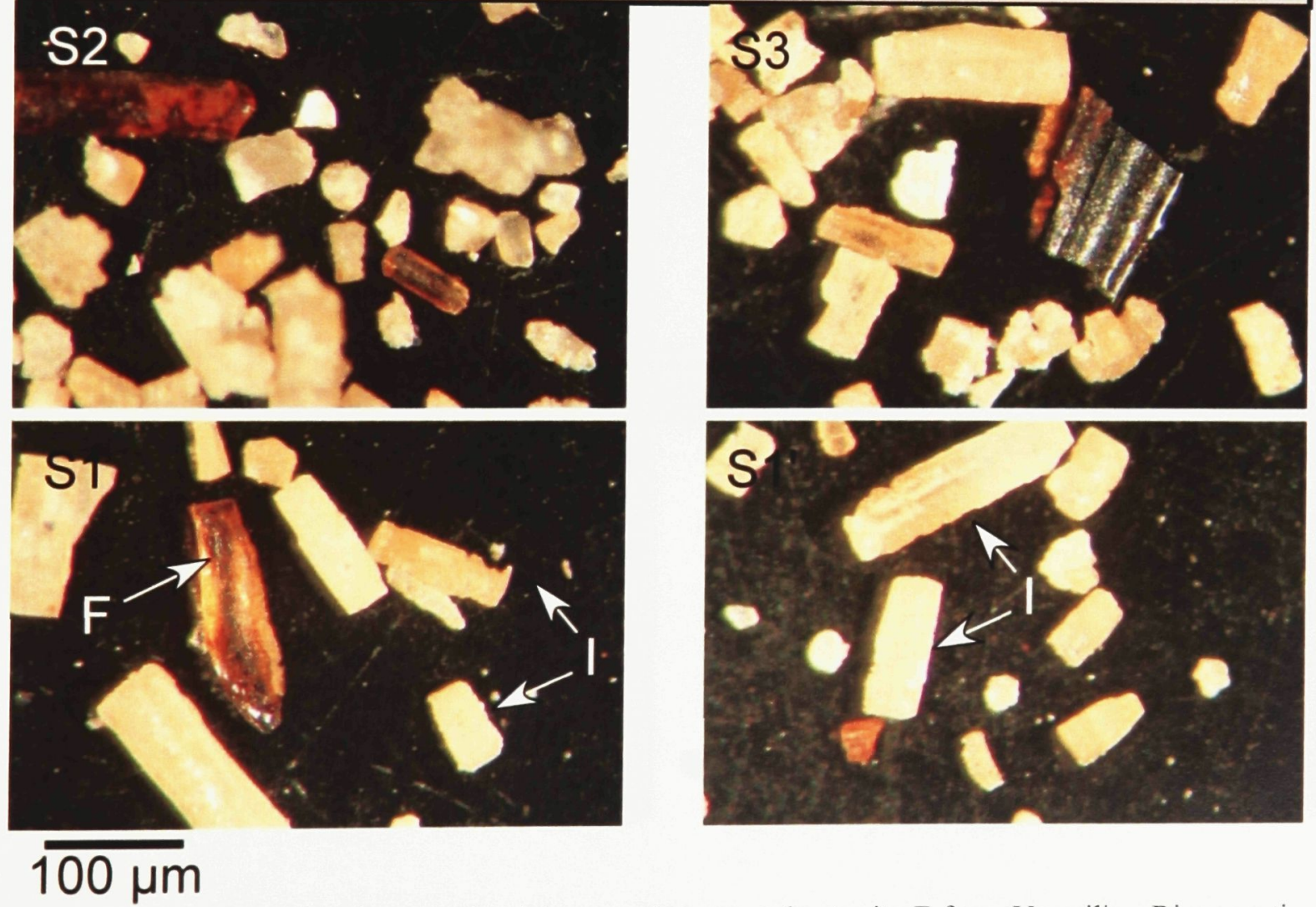

Plate 3: Light-microscope image of residue samples across bentonite F from Vermilion River section V1. The residue is dominated by inoceramid prisms (I), some fish remains (F) but devoid of planktonic foraminiferal shells. The inoceramid prisms are well preserved, but no changes are discernible across the bentonite. 

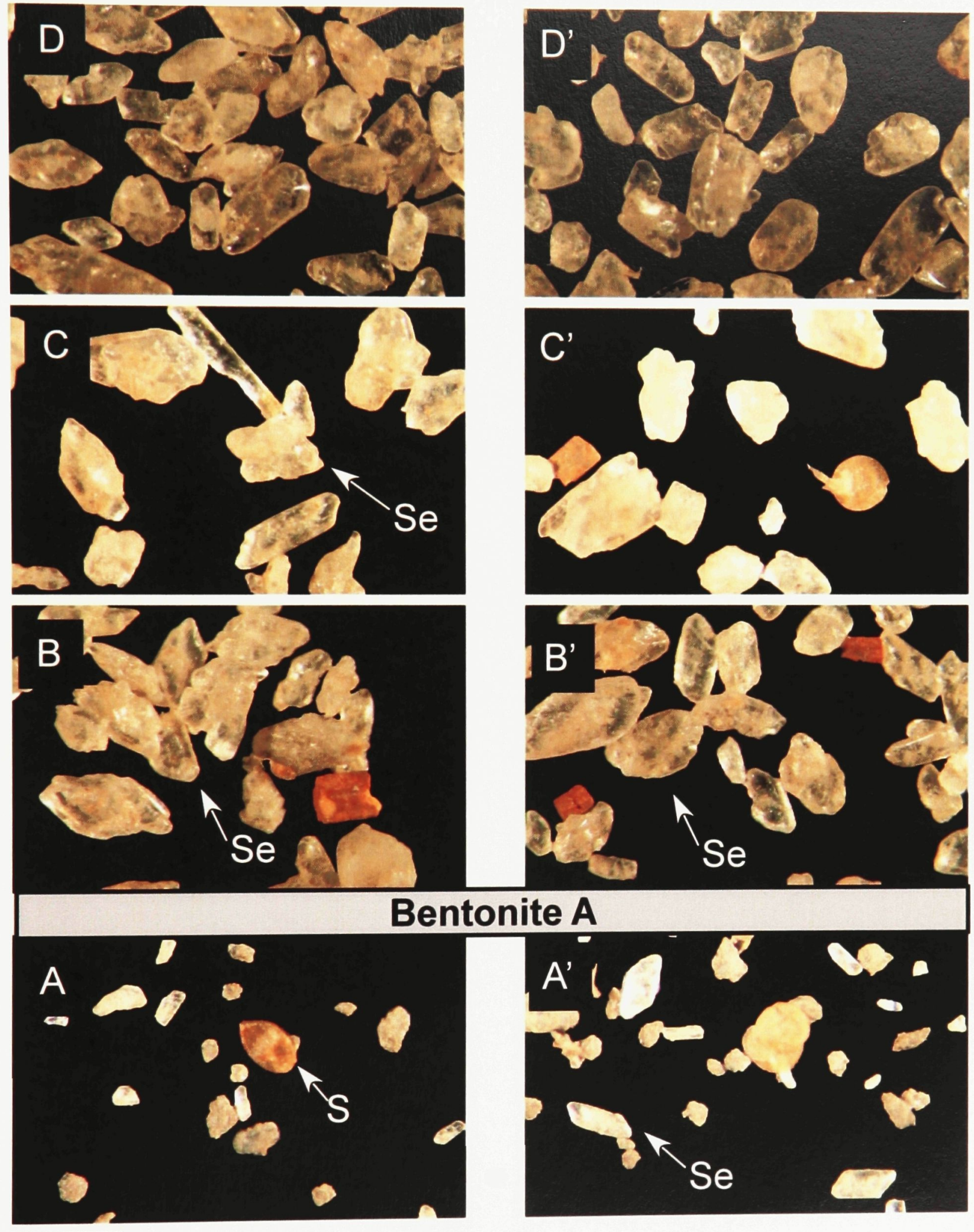

Bentonite A

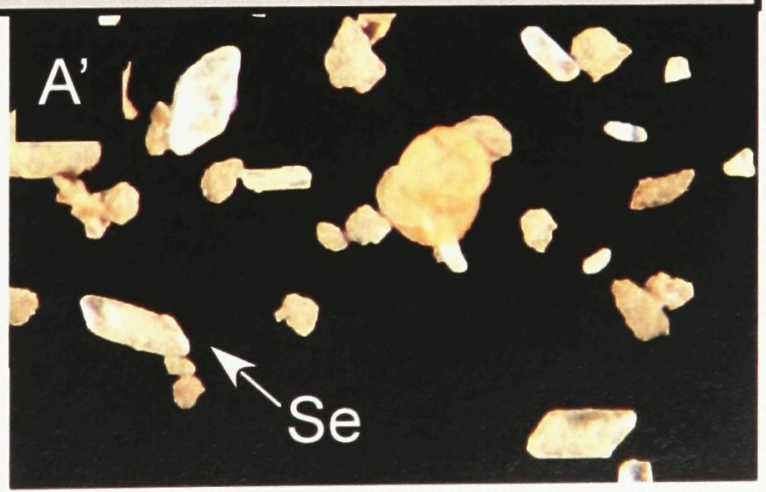

\section{$100 \mu \mathrm{m}$}

Plate 4: Light-microscope image of residue samples across bentonite A from Vermilion River section V2. The residue is dominated by selenite crystals (Se) and some spores (S), but devoid of inoceramid prisms or planktonic foraminiferal. 

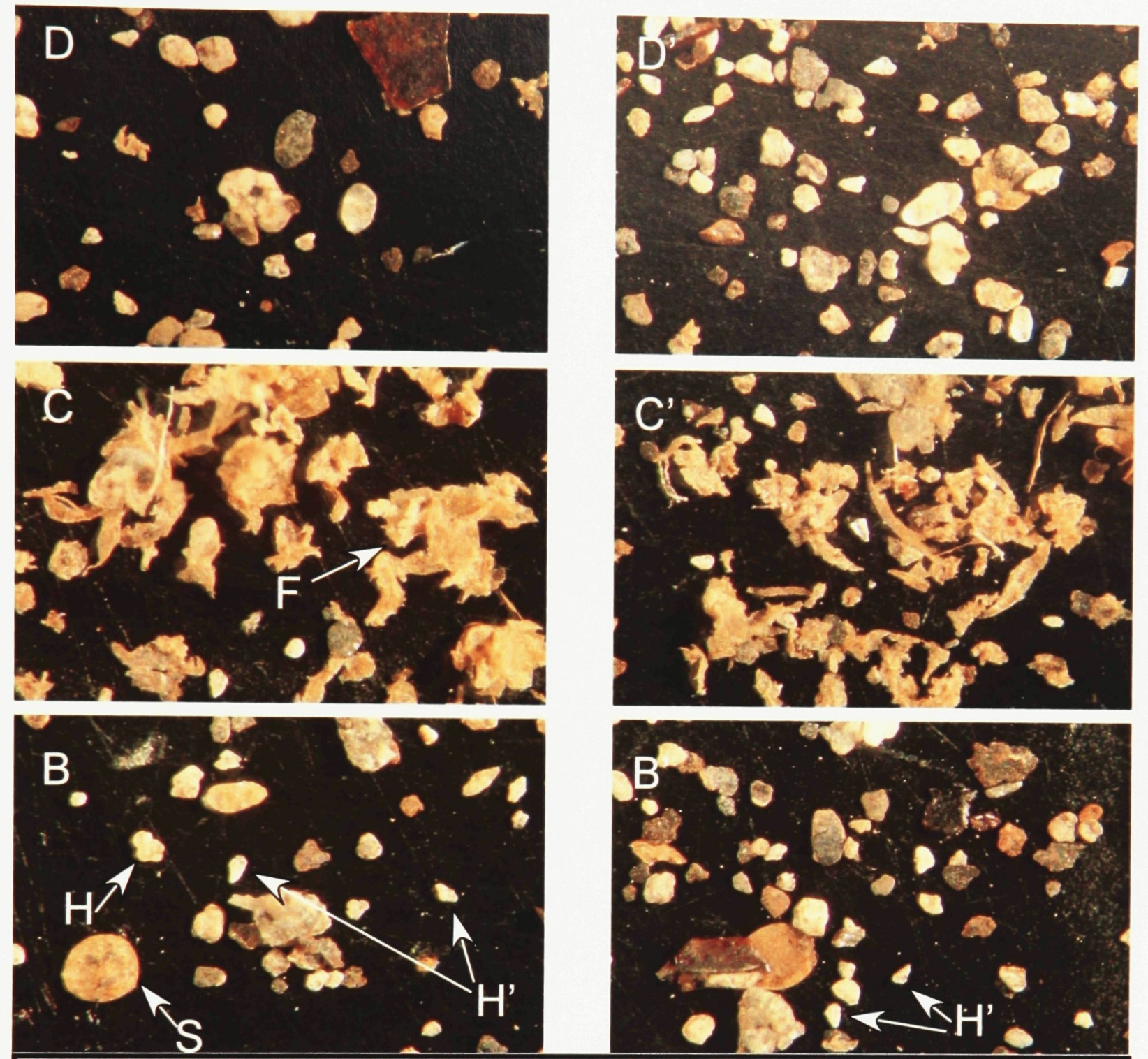

\section{Bentonite B}
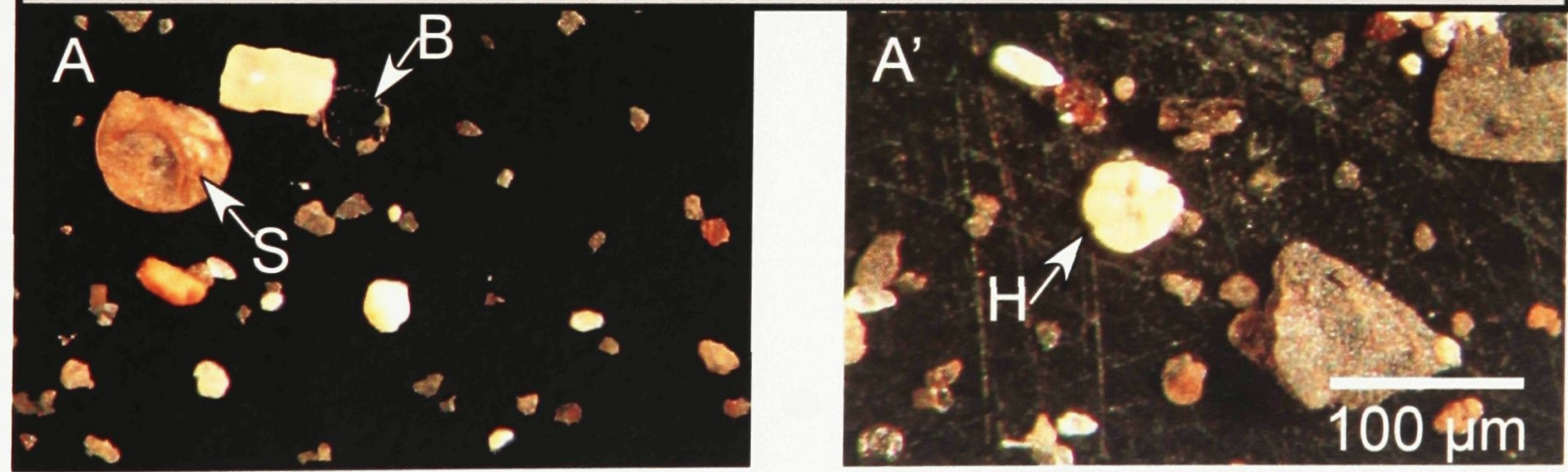

\section{$100 \mu \mathrm{m}$}

Plate 5: Light-microscope image of residue samples across bentonite B from Vermilion River section V2. The residue consists of fish remains (F), biotite (B), spores (S) and some planktonic foraminifera. The noticeable change across the bentonite is the sudden appearance of Heterohelix sp. ( $\left.\mathrm{H}^{\prime}\right)$ in B and abundance of fish remains at $\mathrm{C}$ and $\mathrm{C}$ '. 

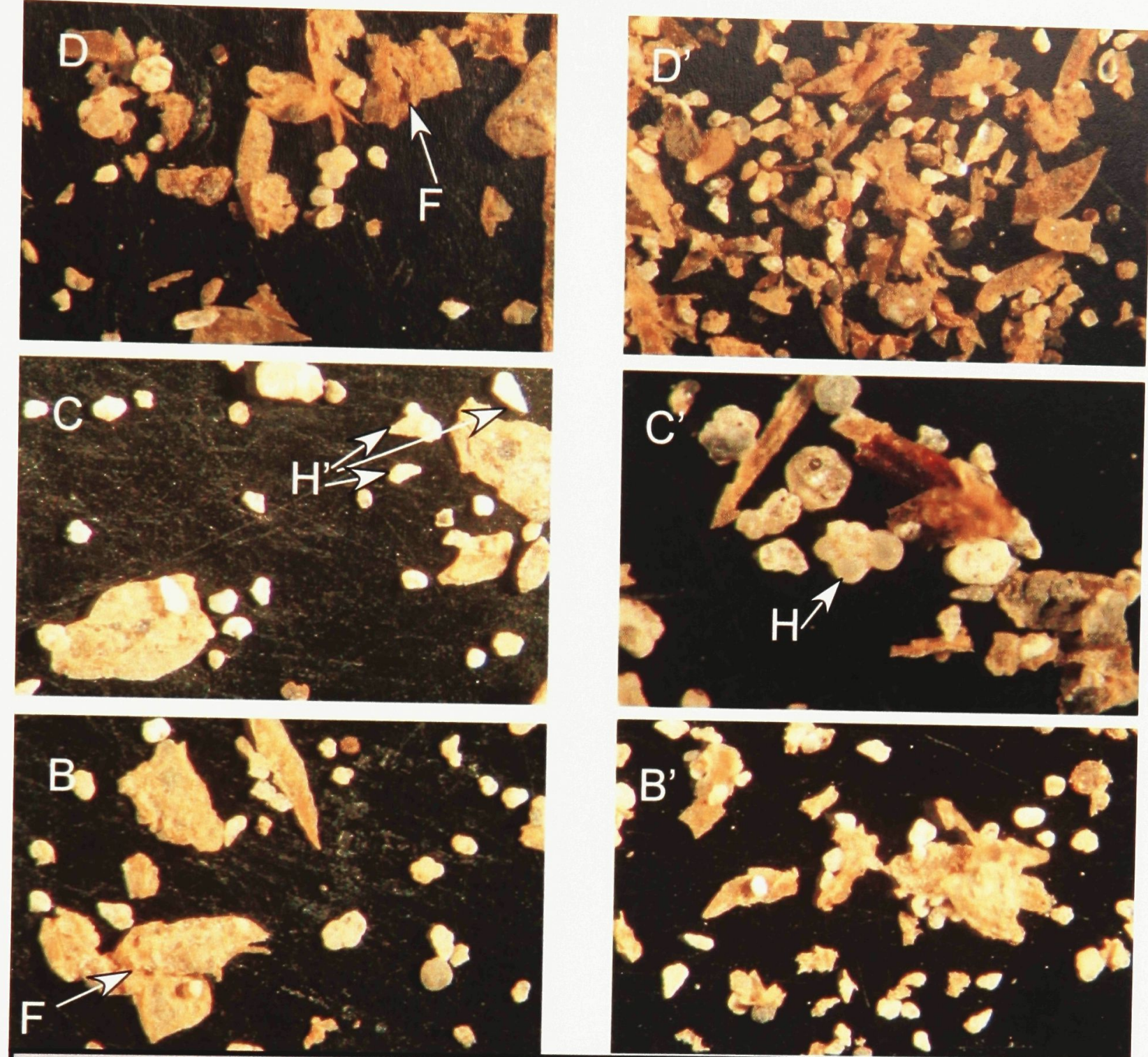

\section{Bentonite C}
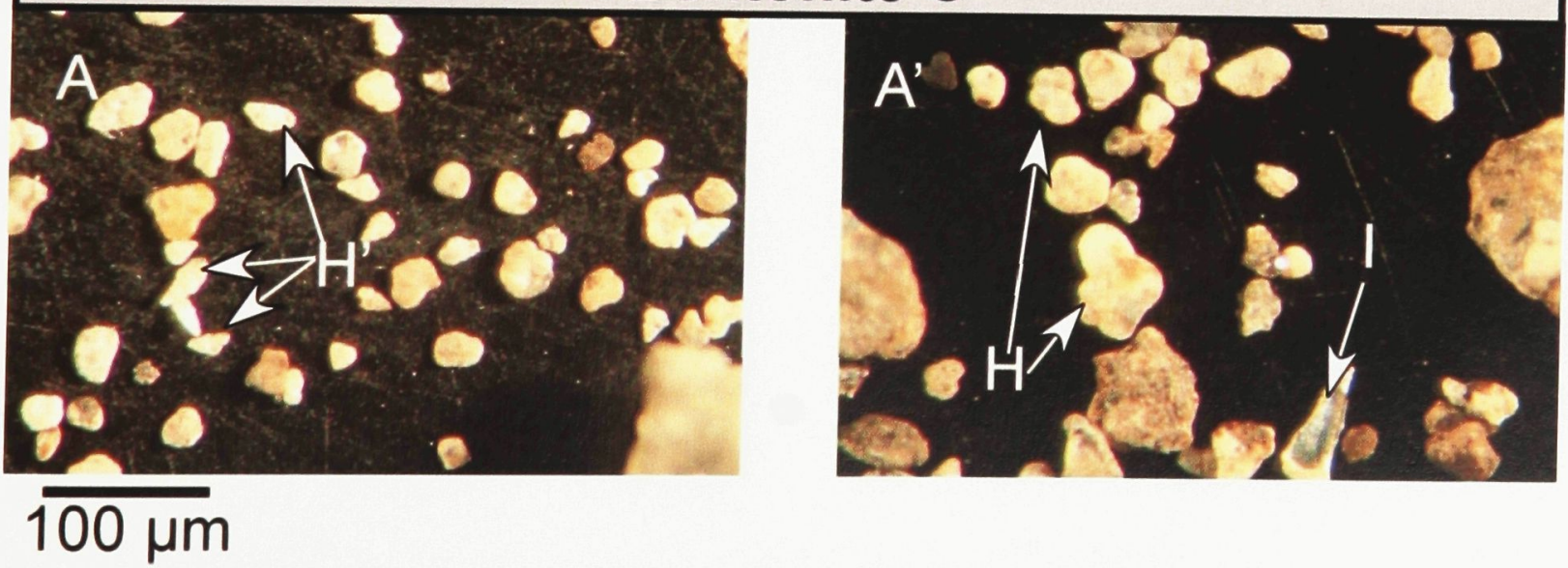

Plate 6: Light-microscope image of residue samples across bentonite C from Vermilion River section V2. The residue consists of fish remains (F), few inoceramid prisms (I) and some planktonic foraminiferal, both Heterohelix (H') and Hedbergella sp. $(\mathrm{H})$ below the bentonite. The foraminifera are well preserved and the noticeable change across the bentonite is the reduction in Hedbergella sp. abundance at B. 

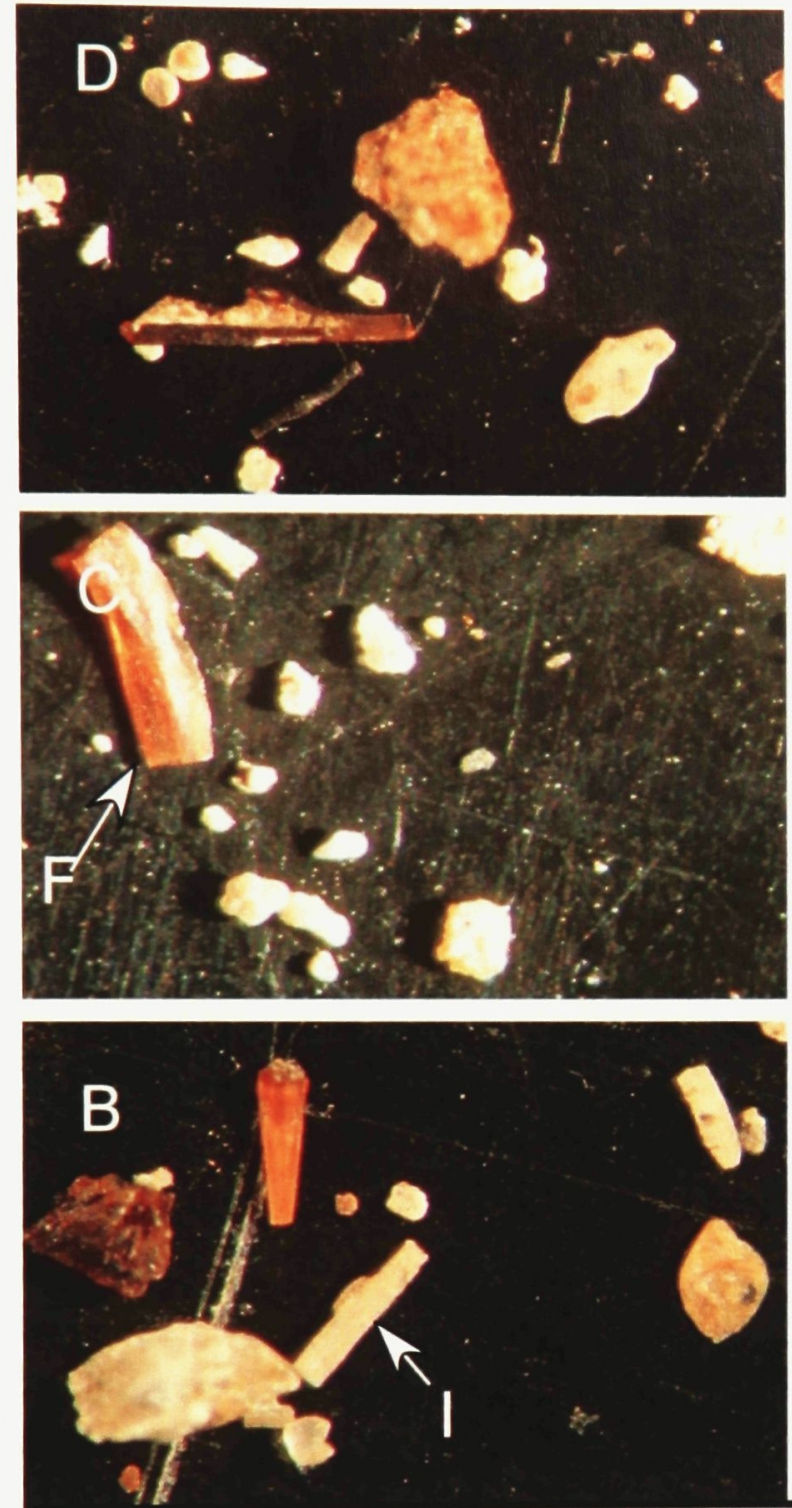
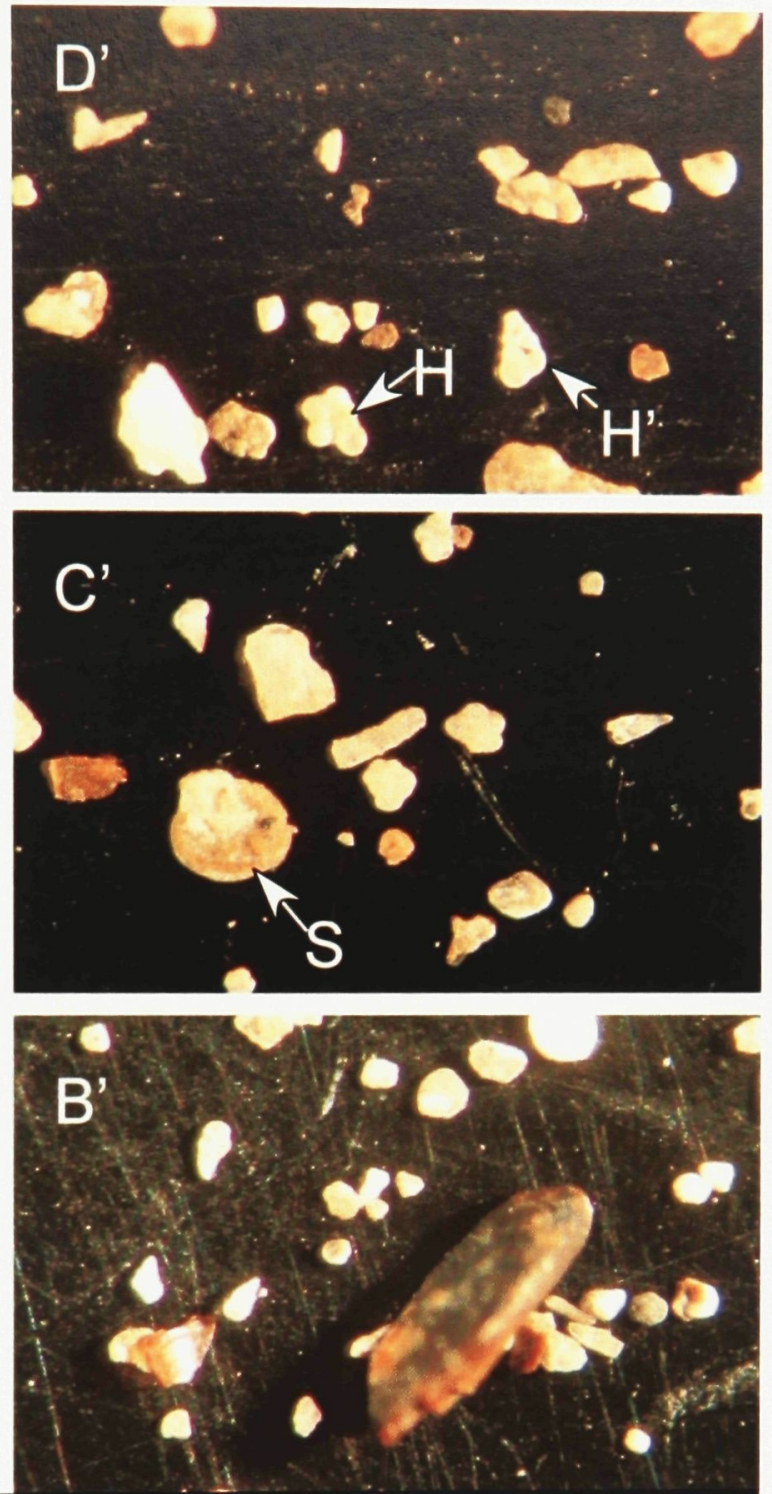

\section{Bentonite D}
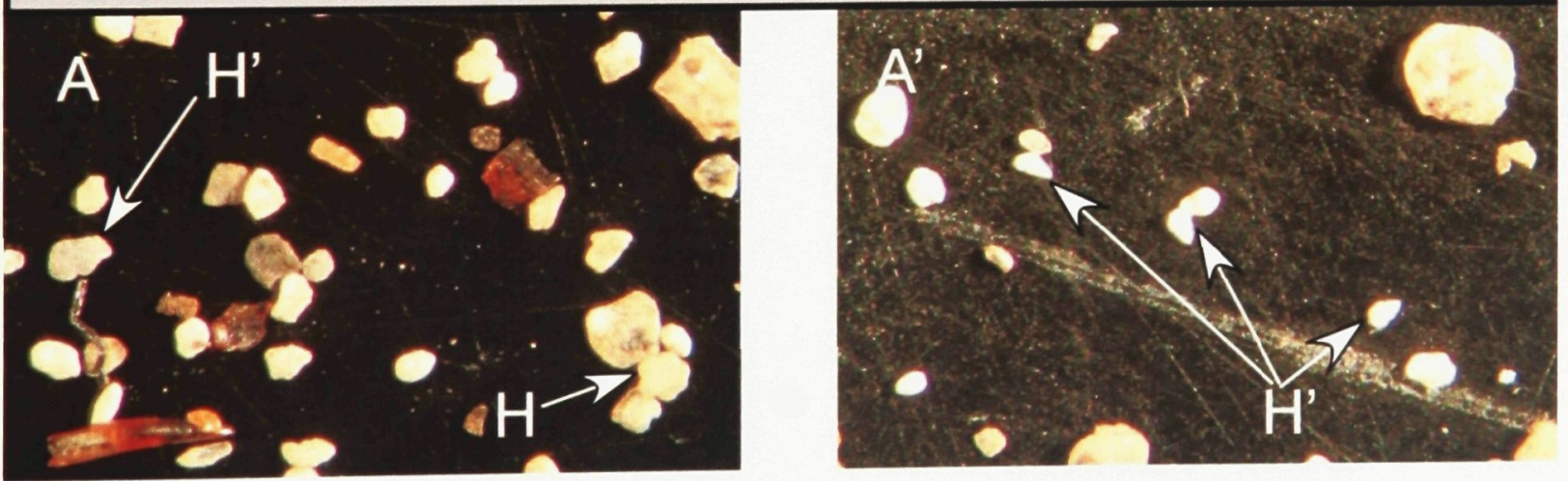

\section{$\overline{100 \mu \mathrm{m}}$}

Plate 7: Light-microscope image of residue samples across bentonite D from Vermilion River section V2. The residue consists of fish remains (F), some spores (S), inoceramid prisms (I) and some planktonic foraminiferal, mostly Heterohelix (H') and some Hedbergella sp. $(\mathrm{H})$ below the bentonite. The Heterohelix sp. Shows a slight size changes across the bentonite while Hedbergella sp. disappear in B \& B' above bentonite $\mathrm{D}$. 

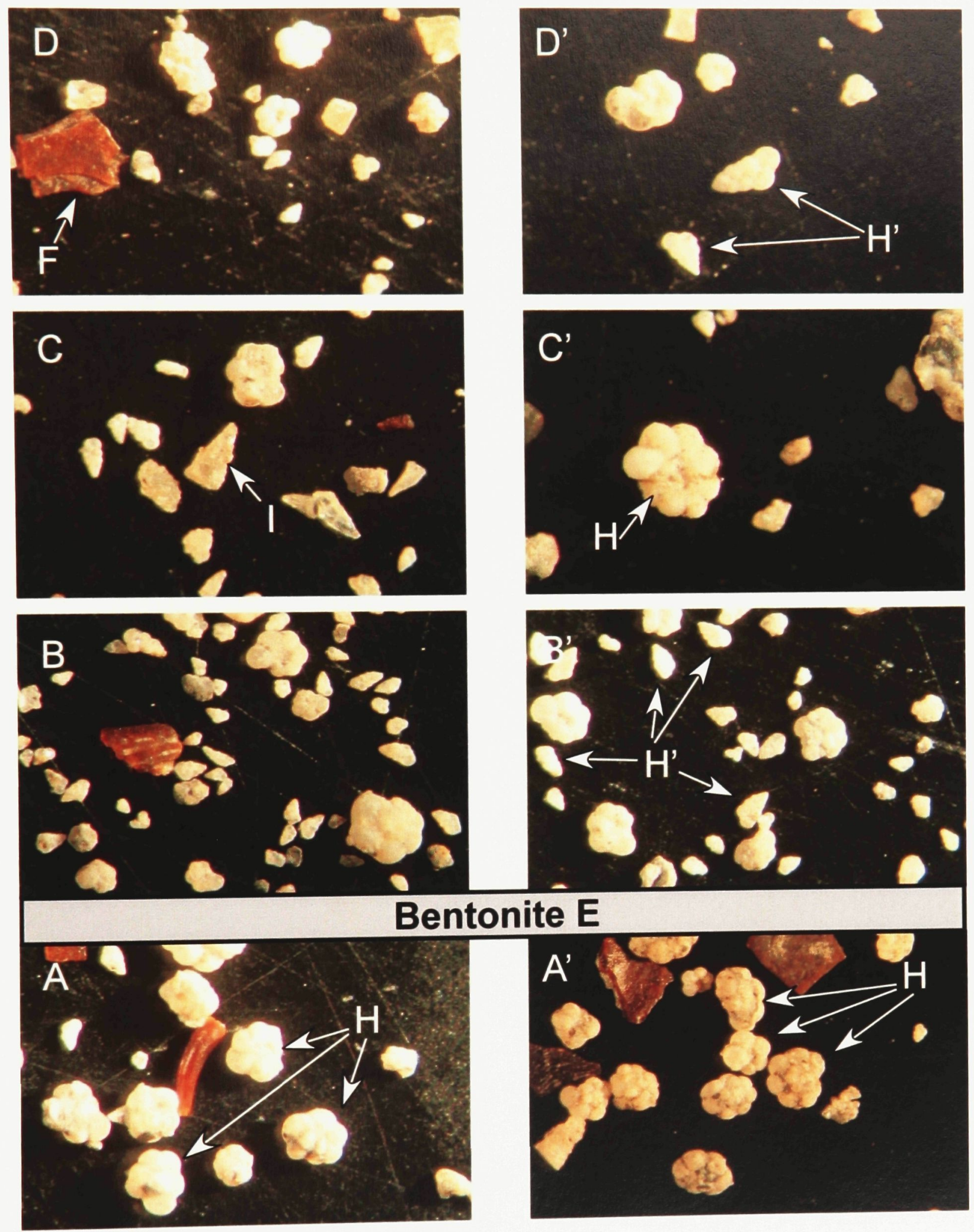

\section{$\overline{100 \mu \mathrm{m}}$}

Plate 8: Light-microscope image of residue samples across bentonite $\mathrm{E}$ from Vermilion River section V2. The residue consists of some inoceramid prisms (I), few fish remains (F) and some planktonic foraminiferal, mostly Hedbergella $(\mathrm{H})$ and some Heterohelix sp. $\left(\mathrm{H}^{\prime}\right)$ below the bentonite. The Heterohelix sp. shows a slight size decrease across the bentonite and later increase abundance. 

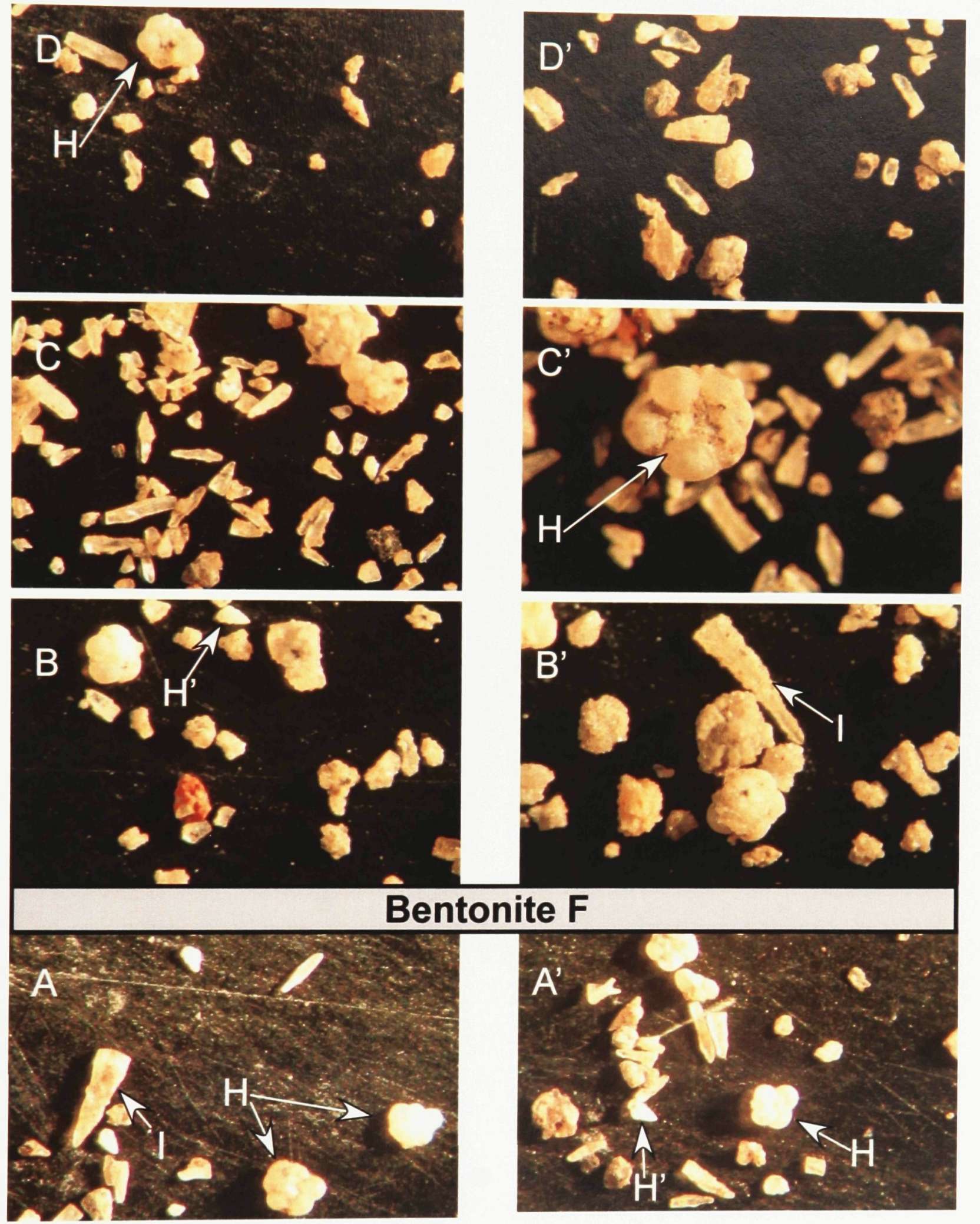

nite $F$

\section{$\overline{100 \mu \mathrm{m}}$}

Plate 9: Light-microscope image of residue samples across bentonite $\mathrm{F}$ from Vermilion River section V2. The residue consists of mostly inoceramids prisms (I) and some planktonic foraminiferal, mostly Heterohelix (H') and some Hedbergella sp. $(\mathrm{H})$ below the bentonite. The Hedbergella sp. shows a slight size changes across the bentonite. 

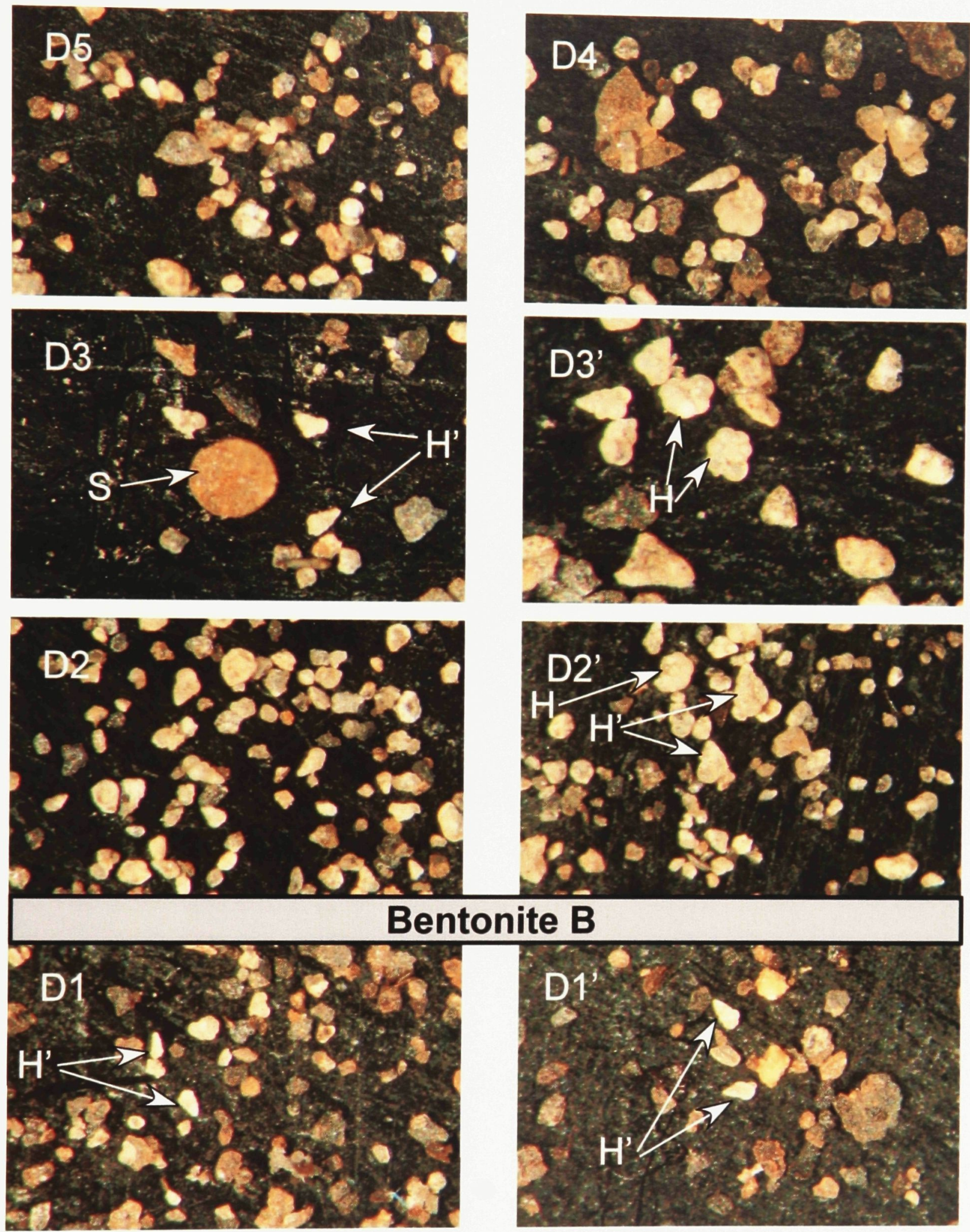

ite B

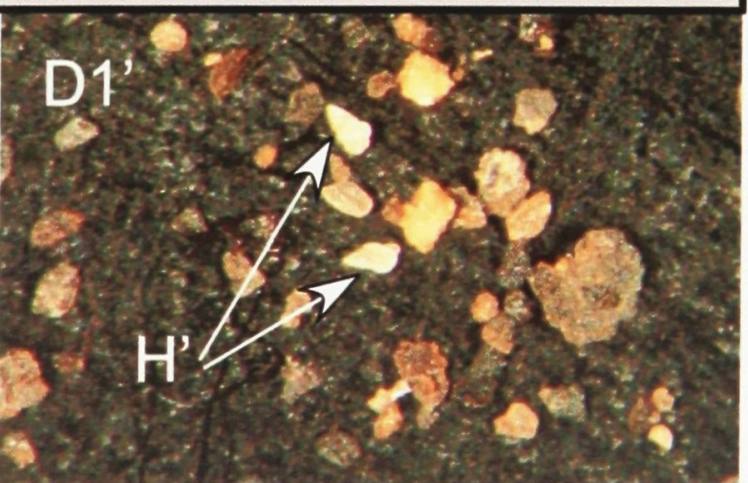

\section{$100 \mu \mathrm{m}$}

Plate 10: Light-microscope image of residue samples across bentonite B from well 6-34-30-8w4 (Youngstown). The residue consists of some spores (S) and planktonic foraminifera, mostly Heterohelix $\left(\mathrm{H}^{\prime}\right)$ and some Hedbergella sp. $(\mathrm{H})$ below the bentonite. The sizes of both Heterohelix and Hedbergella sp. become slightly bigger across the bentonite. 

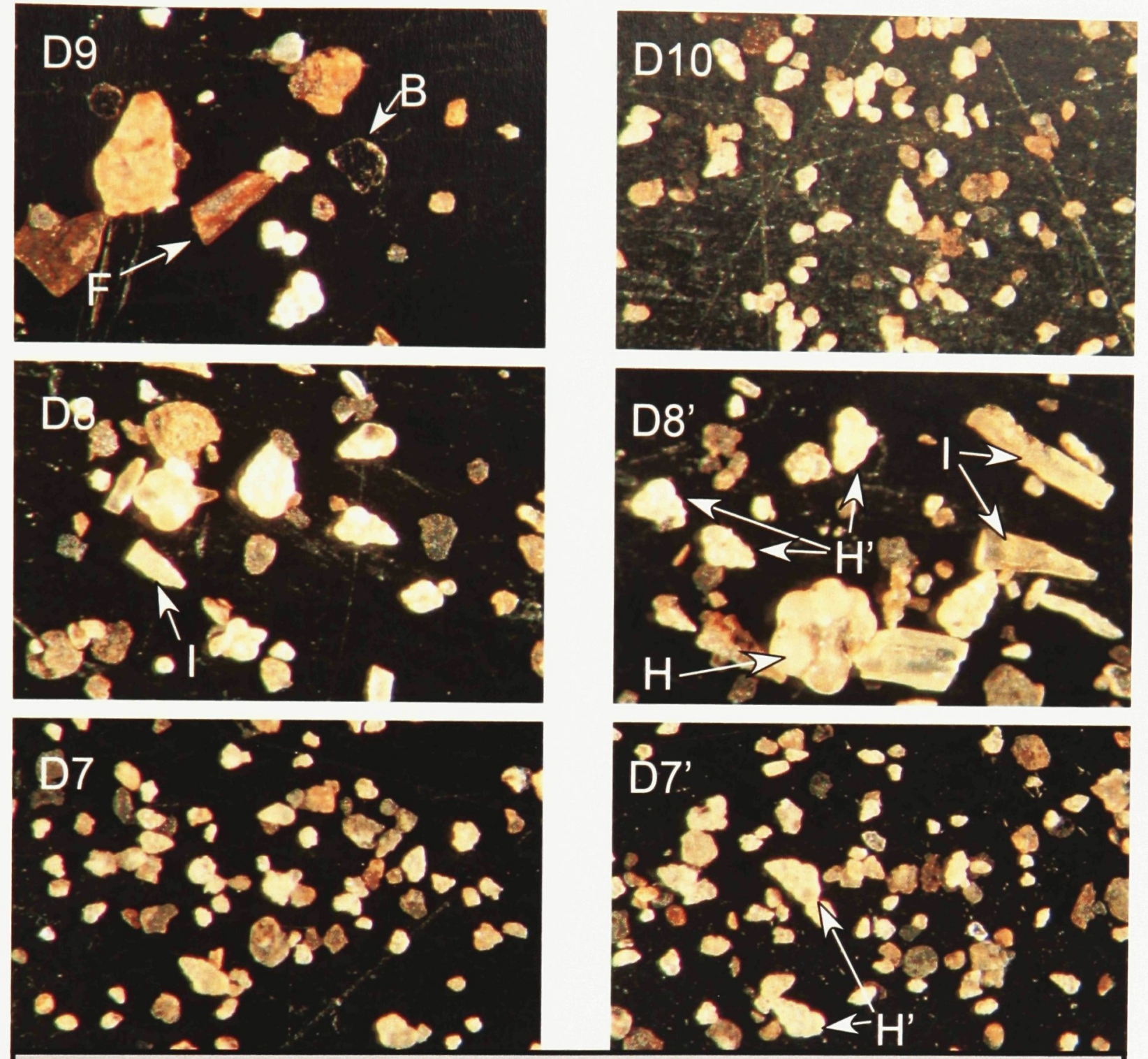

\section{Bentonite A}
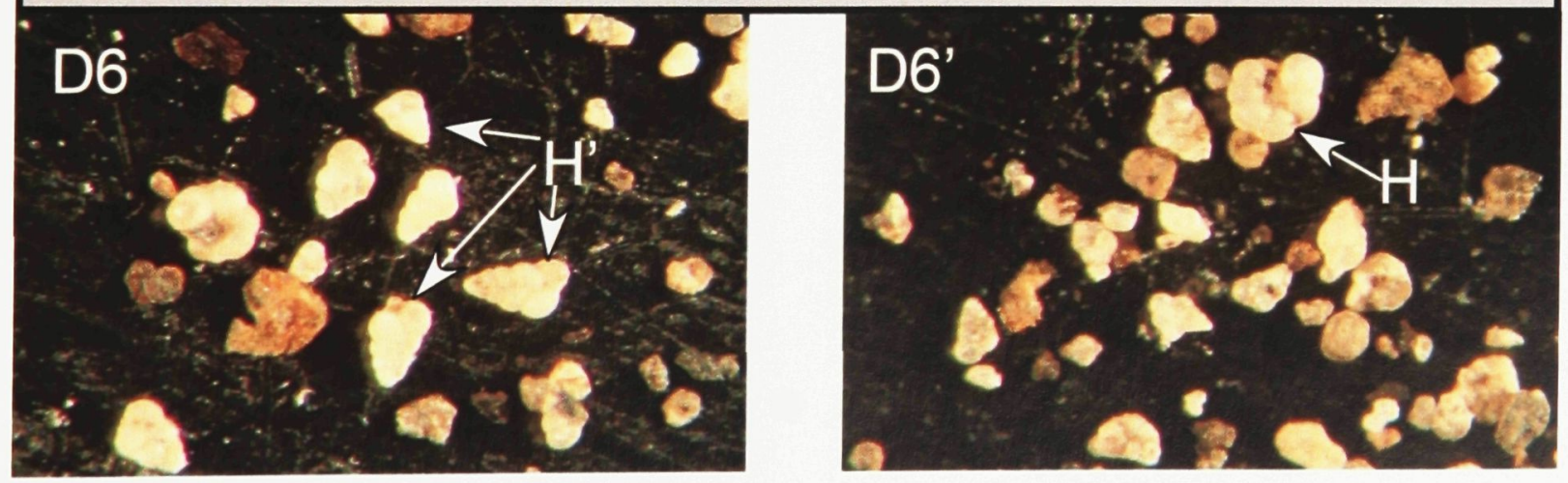

\section{$100 \mu \mathrm{m}$}

Plate 11: Light-microscope image of residue samples across bentonite A from well 6-34-30-8w4 (Youngstown). The residue consists of some fish remains (F), biotite (B), inoceramid prisms (I) and some planktonic foraminifera, mostly Heterohelix ( $\left.\mathrm{H}^{\prime}\right)$ and some Hedbergella sp. $(\mathrm{H})$ below the bentonite. The sizes of Heterohelix sp. initially become smaller across the bentonite, and then become slightly bigger afterwards. 

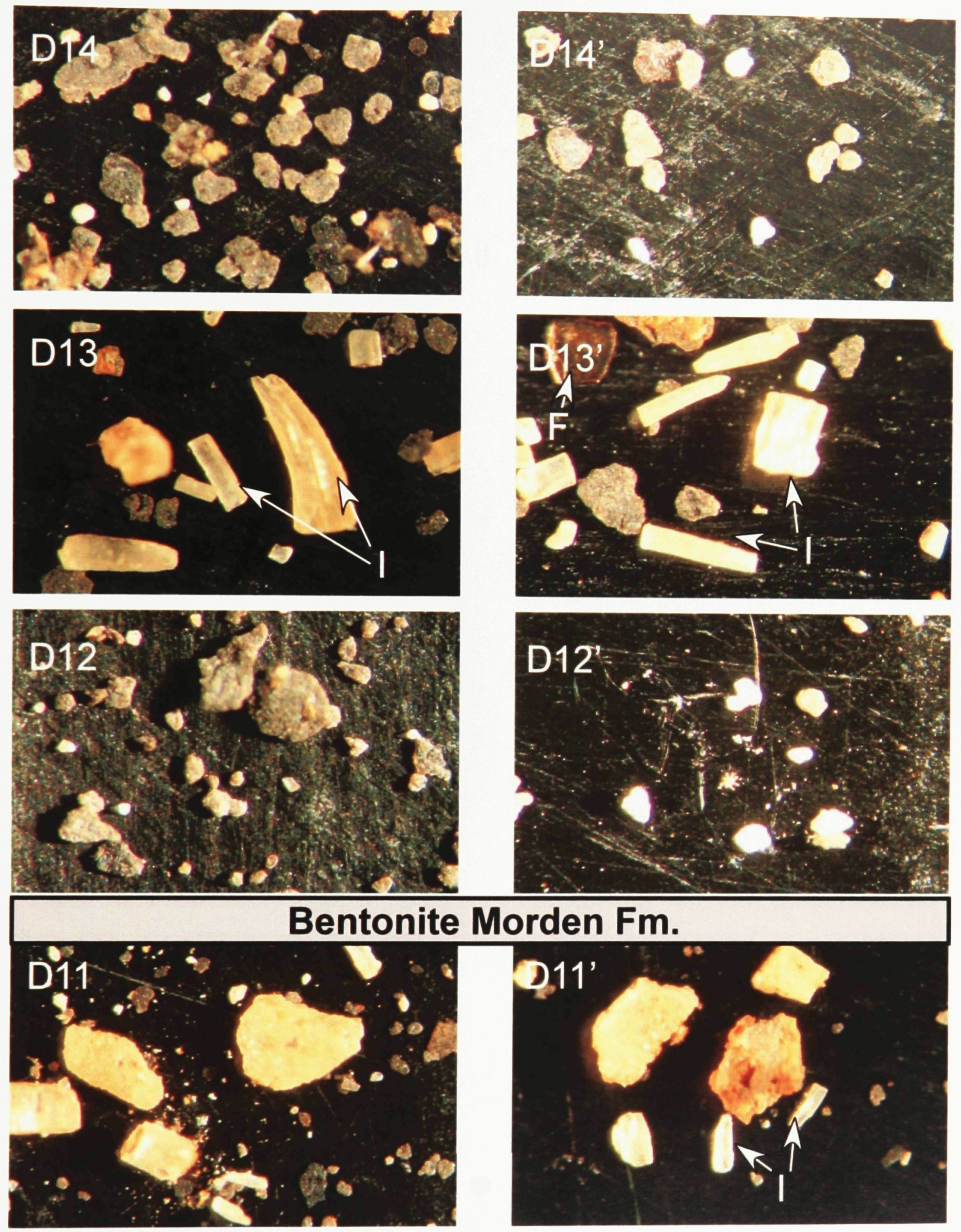

Morden Fm.

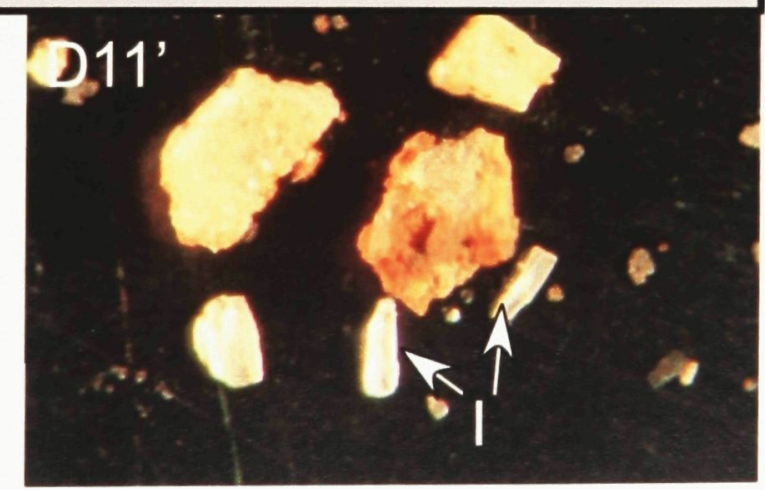

\section{$\overline{100 \mu \mathrm{m}}$}

Plate 12: Light-microscope image of residue samples across bentonite in Morden Fm from well 6-34-30$8 \mathrm{w} 4$ (Youngstown). The residue consists of mostly inoceramid prisms (I) and devoid of any foraminifera. 